\title{
Financial education curriculum for the Adolescent Girls Empowerment Program (AGEP)
}

Population Council

Follow this and additional works at: https://knowledgecommons.popcouncil.org/departments_sbsr-pgy

Part of the Family, Life Course, and Society Commons, and the Gender Equity in Education Commons How does access to this work benefit you? Let us know!

\section{Recommended Citation}

Population Council. 2013. "Financial education curriculum for the Adolescent Girls Empowerment Program (AGEP)." Lusaka: Population Council. 

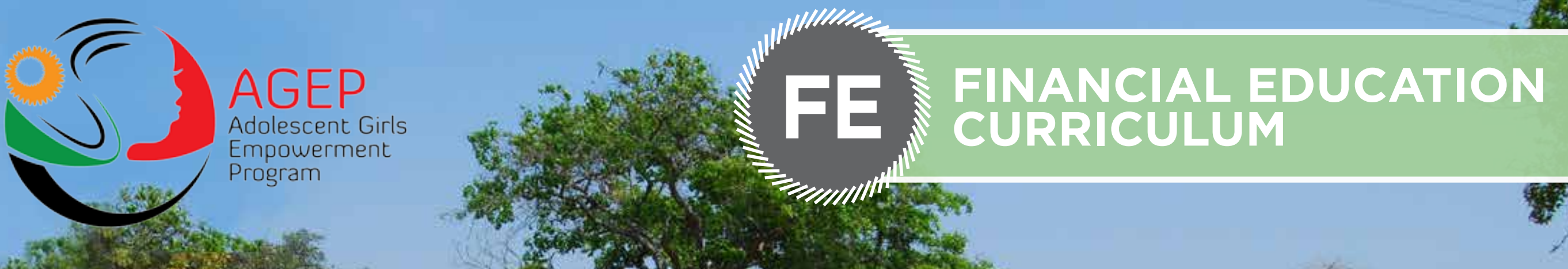

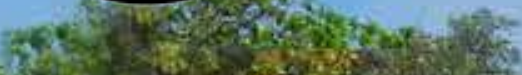
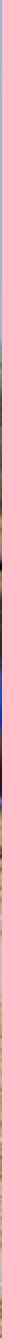


\section{(2) Population Council}

The Population Council confronts critical health and development issues-from stopping the spread of HIV to improving reproductive health and ensuring that young people lead full and productive lives. Through biomedical, social science, and public health research in 50 countries, we work with our partners to deliver solutions that lead to more effective policies, programs, and technologies that improve lives around the world. Established in 1952 and headquartered in New York, the Council is a nongovernmental, nonprofit organization governed by an international board of trustees.

This book is based on and adapted from Young Women: Your Money, Your Future, a book developed by Microfinance Opportunities and the Population Council with support from the Nike Foundation and the Financial Education Fund. This version was developed for the Adolescent Girls Empowerment Program with support from the UK Department for International Development (DFID)

\section{Population Council}

One Dag Hammarskjold Plaza

New York, NY 10017

Tel: 212-339-0500

Fax: 212-775-6092

www.popcouncil.org

Email: publications@popcouncil.org; agep@popcouncil.org; info.zambia@popcouncil.org

Population Council - Zambia

Plot 3670 No. 4 Mwaleshi Road

Olympia Park, Lusaka

P/Bag RW 319X, Lusaka 10101, Zambia

Lusaka, Zambia 10101

Tel: +260 211295925

(c) 2013 The Population Council, Inc.

Written permission from the Population Council is required for any reproduction or distribution of more than fifty (50) copies per year, any electronic reproduction or any major change in content.

For inquiries regarding rights and permission, please contact publications@popcouncil.org.

Sections of this book may be reproduced, translated or adapted with minor changes to meet local needs, provided they are distributed free or at cost and not for profit and provided that any changes maintain the integrity of the book. Please inform the Population Council of plans to translate these materials into another language and provide one (1) copy of the publication.

This curriculum has been adapted from several sources, which are listed in the references section.

Please include the following statements on all section reproductions:

Reprinted from Population Council: Dream Big! Kwacha for Our Future-Financial Education Curriculum. 


\section{FE TABLE OF CONTENTS}

Introduction

Financial Education for Adolescent Girls and

Young Women ........................

How to Use This Guide . . . . . . . . . . . . . . . . . . 1

Some Training Tips and Techniques. ................ 4

Learning Sessions At-a-Glance. .................. 6

Terms and Definitions..................... 7

\section{SECTION 1: DREAM BIG}

1) Dream Big!

\section{SECTION 2: THE STEPS FOR SAVING}

\section{AND EARNING MONEY}

2) Why Save? . . . . . . . . . . . . . . . . . . . . . . . .15

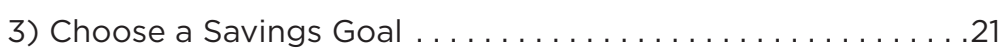

4) Make a Savings Plan. . . . . . . . . . . . . . . . . . . . . . 25

5) Learning About Banks and Bank Accounts. . . . . . . . . . 29

6) Exploring Options for Earning Money . . . . . . . . . . . . 32

7) Girls' Money and the Risky Income Cycle ............. 36

8) Know the Difference Between Needs and Wants ... . . . . . 39

9) Control Spending . . . . . . . . . . . . . . . . . . . . . . 42

10) Think About the Future: Money In and Money Out . . . . . . 46

11) Save Regularly! . . . . . . . . . . . . . . . . . . . . . . . . . . . . . 49

\section{SECTION 3: TALK ABOUT MONEY}

12) Save in a Safe Place ..................... 53

13) Dealing with Setbacks in Saving ................. 56

14) Your Own Money vs. Someone Else's Money . . . . . . . . . . . 59

15) Talking About Money .....................6 63

16) The DOs And DON'TS of Talking About Money . . . . . . . . 67

17) Resolving Conflicts About Money . . . . . . . . . . . . . . . .71

18) Role Play Resolving Conflicts . . . . . . . . . . . . . . . . . . . 75

\section{SECTION 4: CONCLUSION AND REFLECTION}

19) Our Journey to Good Money Management . . . . . . . . . . . 78

Handouts (for easy photocopying) . . . . . . . . . . 82

References ............................. 100 
These financial education learning sessions, collectively titled Dream Big! Kwacha for Our Future, were developed as part of the Adolescent Girls Empowerment Program, funded by a grant from the UK Department of International Development. The overall goal of the program is to help vulnerable adolescent girls in Zambia build their social, health and economic assets. Specifically, in order to build girls' economic assets, they participate in training sessions on financial education, as well as have the opportunity to open savings accounts. The project is led by the Population Council, in partnership with the Young Women's Christian Association of Zambia (YWCA Zambia), the National Savings and Credit Bank (NatSave), Making Cents International, and the Government of the Republic of Zambia.

Many people were involved in the design, testing, and finalization of the learning sessions. The initial sessions that serve as the core source of the sessions in this book, Young Women: Your Future Your Money, were developed by Candace Nelson, Jessica Massie, and Bailey Butzberger of Microfinance Opportunities and Karen Austrian of The Population Council for a similar girls' program in Kenya and Uganda, funded by the Nike Foundation and the Financial Education Fund. Nambula Kachumi, Karen Austrian, Natalie Jackson Hachonda, Diana Bulanda and Bwalya Mushiki of the Population Council; Rathi Mani and David James-Wilson of Making Cents International; David Mukwavi, Mebelo Mebelo, Godfrey Musukwa, and Esther Syapaka of NatSave; and our partners the Bank of Zambia, FHI 360, Churches Health Association of Zambia, Curriculum Development Center, Catholic Relief Services, Micro Bankers Trusts, Junior Achievers, and our AGEP mentors provided invaluable technical assistance in the design, adaptation, and development of these sessions. Their work on the ground in Zambia and their invaluable edits and suggestions contributed to a more appropriate and contextual final product.

\section{PROJECT PARTNERS}

\section{The Population Council, Zambia}

The Population Council confronts critical health and development issues-from stopping the spread of HIV to improving reproductive health and ensuring that young people lead full and productive lives. Through biomedical, social science, and public health research in 50 countries, we work with our partners to deliver solutions that lead to more effective policies, programs, and technologies that improve lives around the world. Established in 1952 and headquartered in New York, the Council is a nongovernmental, nonprofit organization governed by an international board of trustees. The Council's Lusaka office was established in 2009 and has worked to improve the health and well-being of Zambia's poorest and most vulnerable people.

\section{National Savings and Credit Bank}

The National Savings and Credit Bank (NatSave) is a government owned Nonbank Financial Institution that was established in 1972 by a Zambian Act of Parliament. The Bank has firmly positioned itself in the market through its unequaled presence in several districts of the country. Presently, it has 30 branches through which it delivers quality financial products at competitive rates. The Bank further enjoys adequate customer confidence in the market evidenced by the number of active accounts held in its books which top 106,000. Over the years, NatSave has acquired vast experience in providing banking services and customized products to usually unbanked populations in Zambia including farmers, marketers, pensioners, students, and now, adolescent girls.

\section{Making Cents International}

Making Cents International $(\mathrm{MCl})$ is a social enterprise based in Washington, DC that provides specialized technical services and curricula that enable entrepreneurs and enterprises to participate in profitable 
markets; financial institutions to serve new populations; and individuals to obtain meaningful work. Since 1999, Making Cents has partnered with more than 4,000 local organizations in over 50 countries. Their global reach includes programmatic work in Africa, the Americas and Caribbean, Asia,

Europe, and the Middle East. Services address the needs of a range of populations that include youth, women, and vulnerable populations, and are based on an appreciation of client assets and market needs, local capacity building, and a desire to achieve greater sustainable results. As part of its social mission, $\mathrm{MCl}$ also builds and strengthens youth economic opportunities by creating learning opportunities and networks that result in stronger partnerships, programs, and policies supporting young entrepreneurs

\section{YWCA Zambia}

The YWCA is a Christian, nonpartisan, nongovernmental membership organization dedicated to the empowerment of the community, especially women and children, to realize their potential as human beings with a view toward contributing to a just society. The YWCA was established in 1957 and since its inception the organization has always addressed issues of injustice among women and children. Currently, through the women and human rights program, a number of issues have been tabled for debate at various level in parliament.

\section{Department for International Aid}

The Department for International Development leads the UK government's effort to fight global poverty, delivering UK aid around the world. DFID is led by a UK cabinet minister and operates under the International Development Act, which came into force in 2002. DFID's overall aim is to reduce poverty in poorer countries, in particular through achieving the Millennium Development Goals. Key issues that DFID is focusing on in over 30 countries are education, health, economic growth and the private sector governance and conflict, climate and environment, water and sanitation, food and nutrition, and humanitarian disasters and emergencies. As part of its work, DFID is committed to the achievement of gender equality and the empowerment of women and girls. 


\section{FINANCIAL EDUCATION FOR ADOLESCENT GIRLS AND YOUNG WOMEN}

Adolescent girls and young women like us are on the edge; we stand at the gateway to adulthood and a future full of responsibilities about which we are not always fully aware. We often find ourselves teetering between dependence on childhood caretakers and the independence we crave as young adults. We are experimenting with new social relationships and we are assuming more financial responsibilities. This tumultuous period is also the critical time for young people like us to face our futures and begin preparing for the economic roles we will assume as adults. Teaching ourselves how to manage our money and build assets can help us protect ourselves and expand our opportunities. This is the role of financial education and this is the reason for the Dream Big! Kwacha for Our Future curriculum.

\section{WHY IS FINANCIAL EDUCATION IMPORTANT FOR ADOLESCENT GIRLS AND YOUNG WOMEN?}

At a basic level, financial education focuses on concepts of money and ways to manage it well. It promotes regular saving, wise spending, and ways to make the most of our resources. These skills serve as a foundation for girls and young women like ourselves, who are transitioning from dependent to independent roles in our financial responsibilities. We are shifting from depending on our families for support to earning our own money and making independent financial decisions. At a very basic level, we must know how to handle ourselves, pursue income opportunities, pay for our expenses, and plan for the future. However, we also know that in a few years' time, we will become young women and have more responsibilities for marriage, households, children, as well as additional responsibilities related to employment, shelter, and relationships.

Therefore, we know that financial education will help us to manage our dayto-day expenses now, but also in the future. Good money management can minimize some of the risks we face in our lives, and build financial support for the future.
These are skills that we adolescent girls and young women need now and will need every day of our adult lives. An investment in financial literacy for adolescent girls sets the stage for the many changes that are coming. It will increase our ability to manage money, as well as confidence and readiness for the future. Financial knowledge can open up new opportunities to work, build assets, and save. Access to and control over savings can help to protect us against, mitigate, and cope with many risks associated with adolescence-by providing resources to draw upon in times of need.

\section{HOW TO USE THIS GUIDE}

Dream Big! Kwacha for Our Future is a collection of learning sessions designed to prepare adolescent girls and young women for the financial responsibilities of adulthood, providing them with the knowledge and skills to transition from economic dependence to independence. These sessions were developed to be delivered without a lot of resources or materials, with limited time available for training. The guide contains step-by-step descriptions of the learning activities as well as background information to orient you, the trainer, to the topic.

\section{The Learning Sessions}

This module contains 19 core learning sessions. Each session takes between 30 and 60 minutes to complete. The "Learning Sessions at a Glance" on page 18 provides an overview of the sessions, listing the title and purpose of each.

Sessions 1 and 2 introduce the concept of "dreaming big" and provide a rationale for saving and making savings goals. Sessions 3 through 11 focus on the "Eight Steps for Savings," eight concrete steps that girls can take to increase their savings and save effectively and safely, as well as provide an introduction to banks. This section also explores the various types of income and how particular sources of earning income could bring about possible risks. Sessions 12 through 18 focus on financial negotiations. Participants learn about good communication skills and practice how to resolve conflicts about money. Finally the wrap up (Session 19) offers participants an opportunity to reflect on how far they have come on the journey to good money management. 


\section{CURRICULUM STRUCTURE}

These learning sessions were developed as part of the Adolescent Girls Empowerment Program. The overall goal of AGEP is to help girls build social, health and economic assets in a safe and fun learning environment. During weekly group meetings, girls will be trained on financial education through this curriculum, in addition to health and life-skills topics.

The complete financial education (FE) curriculum is included here. However, the girls' groups will meet over the course of two years and it is anticipated that the financial education sessions will be integrated with the health and life skills curriculum (HLS). The proposed full session order is as follows:

\section{HLS Introductory Sessions}

Session 1: What to Expect - Part 1

Session 2: What to Expect - Part 2

Session 3: Teamwork

Session 4: His and Hers (Gender Roles)

Session 5: Communication

Session 6: Self-Esteem

\section{Introduction to Financial Education}

Session 1: Dream Big!

Session 2: Why Save?

Session 3: Choose a Savings Goal

Session 4: Make a Savings Plan

Session 5: Learning about Banks

\section{HLS Introductory Sessions}

Session 7: Goal Identification - The Road of Life

Session 8: Goal Setting and Achieving

Session 9: My Relationships

\section{ROUND 1}

HLS

\section{Reproductive Health}

Session 1: Life Cycle

Session 2: My Body Is Changing - Am I Normal?

Session 3: How Does Pregnancy Happen, Anyway?

Session 4: Preventing Unintended Pregnancy (Contraceptives)

Session 5: Reproductive Myths

\section{Financial Education}

Session 6: Exploring Options for Earning Money

Session 7: Girls' Money and the Risky Income Cycle

\section{Life Skills}

Session 1: I Have Healthy Relationships

Session 2: Reasons to Delay Sex

Session 3: Strategies to Delay Sex

Session 4: Passive, Assertive, Aggressive

HLS HIV, AIDS, and STIs

Session 1: HIV and AIDS

Session 2: Myth or Fact?

Session 3: HIV Testing and Counseling

\section{Financial Education}

Session 8: Know the Difference Between Needs and Wants

Session 9: Control Spending

Session 10: Think About the Future: Money In and Money Out

Session 11: Save Regularly!

Session 12: Save in a Safe Place

Session 13: Dealing with Setbacks in Saving

LS Gender and Gender-Based Violence

Session 1: Sexual Exploitation

Session 2: How to Report and Avoid Cases of Sexual Violence

Leadership

Session 1: Leadership

Session 2: Community Service: Putting Leadership in Action 


\section{ROUND 2}

HLS

Session 6: Sexual Desire

Session 7: Unsafe Abortion

Session 8: Abortion and Stigma

Session 9: Maternal Mortality

\section{HLS Life Skills}

Session 5: Drugs, Alcohol and Other Mind-Altering Substances Session 6: Peer Pressure

Session 7: Making Good Decisions

Session 8: How to Communicate with Adults

\section{Financial Education}

Session 14: Your Own Money Vs. Someone Else's Money

Session 15: Talking About Money

Session 16: The DOs and DON'Ts of Talking About Money

Session 17: Resolving Conflicts About Money

Session 18: Role Play Resolving Conflicts

Session 19: Our Journey to Good Money Management

\section{HLS Human Rights}

Session 1: Human Rights and Children's Rights

Session 2: Sexual and Reproductive Health Rights

Session 3: HIV and AIDS and Human Rights

\section{HLS HIV, AIDS, and STIs}

Session 4: Risky Behavior

Session 5: The Relationship of STIs and HIV and AIDS

Session 6: Stigma and Discrimination in HIV-Positive People

\section{HLS Gender and Gender-Based Violence}

Session 3: Rape and Gender Violence

Session 4: Preventing Unwanted Advances

\section{HLS Life Skills}

Session 9: How to Communicate with a Partner

Session 10: Managing Stress, Anger, and Conflict

Session 11: Conflict Resolution and Problem Solving Skills
For more information about the Adolescent Girls Empowerment Program, please visit: http://www.popcouncil.org/projects/353_ZambiaAGEP.asp.

For any inquiries, please contact: agep@popcouncil.org.

\section{BE PREPARED IN ADVANCE!}

Because the learning sessions are spelled out in detail, you do not have to create anything from scratch. However, you must review the sessions and prepare any necessary materials before the training begins. The success of the learning sessions depends on your work at this stage.

Some of the sessions contain special features. These features are explained in detail in the learning session where they are found, and an overview is provided below:

- SWOT Exercise: Session 1 requires you to teach SWOT Analysis to girls. SWOT is a simple way to evaluate Strengths, Weaknesses, Opportunities, and Threats for any given topic. Review the session and Content Note before teaching it to girls, so that you understand the concept well in advance.

- Stories: A total of nine stories are included in the learning sessions. These stories illustrate different aspects of girls' lives to bring the lessons to life. Make sure to read these stories before you deliver them, so that you tell these stories in a lively manner, without reading directly from the page. If you have a photocopy machine available, you may make copies for each girl.

\begin{tabular}{|c|c|}
\hline SESSION & STORY \\
\hline 1. Dream Big! & - Chikondi's Story \\
\hline 3. Choose a Savings Goal & - Monica's Story \\
\hline $\begin{array}{l}\text { 6. Exploring Options for Earning } \\
\text { Money }\end{array}$ & - The Story of Nambula \\
\hline $\begin{array}{l}\text { 8. Know the Difference Between } \\
\text { Needs and Wants }\end{array}$ & - The Story of Bwalya and Mutinta \\
\hline $\begin{array}{l}\text { 10. Think About the Future: Money In } \\
\text { and Money Out }\end{array}$ & - Mwaka's story \\
\hline 11. Save Regularly & - Two Cousins Save \\
\hline 12. Save in a Safe Place & $\begin{array}{l}\text { - The Story of Mulenga } \\
\text { - The Story of Sara }\end{array}$ \\
\hline 13. Dealing with Setbacks in Saving & - The Story of Hellen \\
\hline
\end{tabular}


- Role Plays: Sessions 17 and 18 have role play components. If the girls in your group enjoy working together outside of the savings group meetings, you may choose to have them prepare role plays together and present them during the meetings. This can save time and increase opportunities for the practice and application of the learning.

- Pictures: Another way of making learning sessions more lively and engaging is to include pictures. Sessions 1, 4, and 9 contain pictures. Pictures in session 4 are provided as cards with the Trainer's Guide. However, if you lose a card, or prefer not to use the cards, you can simply show the girls the pictures directly from your Trainer's Guide. Alternatively, you can bring in real objects to represent the pictures.

- Steps/Activities: Each session is divided into one to four activities, each with an estimate of the amount of time. This can help you to organize each session and prepare for each component. Activities are organized so that they typically review from the last session, introduce a new concept, give the girls a chance to apply the new concept, and then wrap up.

- Suggested Visitors: Session 6 is an ideal session to follow with a visit from a woman (or women) from the local community to speak about options for earning money. However, we suggest that any time it is convenient and possible to bring in a guest speaker, you do so. Girls will always benefit from meeting and learning from women they identify with who can serve as positive examples and/or role models.

As you read the step-by-step instructions, give yourself permission to imagine a training session that is active, sometimes noisy, and fun. As the trainer, you will not be doing all the talking. Instead, you will be part of a dynamic learning process.

\section{SOME TRAINING TIPS AND TECHNIQUES}

This Trainer's Guide is full of activities that require organizing participants into pairs or small groups. The instructions frequently direct you to do this, but usually leave the method up to you, the facilitator. This section offers a mini catalog of techniques for forming pairs and small groups. Ideas for facilitating group introductions are also included. You will find these handy at the opening of a workshop, and you may also find reason to do introductions again at a later time.

\section{A. Forming Pairs}

1. Form pairs by dividing the total number of participants in half. Ask participants to count off up to the number that represents half of the total. For example, if you have 20 participants, they will count off up to 10 and then start again at 1. The two people who have the same number are partners (the $1 \mathrm{~s}, 2 \mathrm{~s}, 3 \mathrm{~s}$, etc.).

2. Ask participants to turn to the person on their right (or left). This person is their partner.

3. Create sets of pairs constructed around opposite words or similar objects or first and last names of famous people. The number of pairs you create should equal half the number of participants. Each pair must have two parts. Write one word of each pair on a slip of paper. Ask participants to draw a slip of paper from a container and find the other half of their pair. This is their partner. Some examples for a group of 10 participants include:

\begin{tabular}{|l|l|l|l|l|l|}
\hline Opposites & Matching objects & Famous people \\
\hline black & white & bed & sheets & Nelson & Mandela \\
\hline sad & happy & table & chair & Bob & Marley \\
\hline dark & light & camera & photograph & Sakala & Brothers \\
\hline tall & short & car & driver & Michelle & Obama \\
\hline wide & narrow & shoes & Socks & Levy & Mwanawasa \\
\hline
\end{tabular}

The group's theme can provide the inspiration for your selection of paired words. Or, select famous people who are relevant to the age range of your participants. For example, music, sports, and movie stars tend to work well with young people.

\section{B. Group Introductions}

When you first begin meeting together as a group, all participants should introduce themselves. You can make this as fun or as serious as you feel is appropriate. Here are some ideas for introductions:

1. Participants can simply give their name and their school, or the area they live. Or you can ask each person to say something unusual about herself, to help the others remember her.

2. Go around and instruct participants to state their name, occupation, town of residence, plus one of the following: favorite food, favorite animal, or favorite movie star. You can be creative and think of a different category that may be more enjoyable or relevant to your participants. 
3. Distribute paper and markers or colored pencils to each participant. Ask them to draw a picture that tells the others something important about themselves. Give them five minutes to draw. Then, one by one, ask each person to give their name and explain her picture. Additionally, you can collect the pictures, post them on the wall or on a tree, and sometime later in the day have a contest to see who can match names to pictures.

4. Instruct participants to form pairs (see Section A above), and tell the partners to introduce themselves to each other. Give them five minutes to talk to each other. Then ask each person to introduce her partner to the group.

5. Ask participants to form a circle. Explain that each person must state certain information when introducing herself (you might add "something different or special about yourself" to the normal information like name, school, favorite food, or main interests). Then toss a soft ball (or rolled up sock or ball of yarn) to someone in the circle who introduces herself. After she has introduced herself, she tosses the ball to someone else in the circle. The game continues unti each person has had a chance to give an introduction.

\section{Ways to Form Groups}

1. Count off. For example, ask participants to count off by $4 \mathrm{~s}$. One by one, each participant will say a number (the first participant says "1," the second says " 2 ," and when it is the fifth participant's turn, he will start again at 1). When everyone has counted, instruct participants to form groups with people who have the same number. In the end, you will have four groups.

2. Make simple puzzles with 3-5 pieces each. Distribute the puzzle pieces to participants and ask them to find all of the others who have the pieces to complete their puzzle. Be sure to use simple puzzles and have the same number of puzzle pieces as participants. See Chapter 2, Session 2 for sample puzzles that you could adapt to this exercise.

3. Ask participants to stand in line in the order of their birthdays-month and day only-and then count off (such as 1 through 3 ) to form groups.

4. Assign colors, symbols, or pictures at random. Instruct participants to find all others with the same assigned color, symbol, or picture.

5. Place the names of four well known pop culture stars in different places around the room and ask participants to stand next to their favorite. If everyone flocks to the same star, you will have to adjust the exercise so that you end up with more than one group. For example you can ask participants to move to their second favorite star.

6. Select four different animals (or whatever number of groups you want to create) and write the name of each animal on several slips of paper. The number of slips will depend on how many participants will be in each group. For example, if you have 16 participants, you can make four groups of four people. In that case, you will write the name of each animal on four slips of paper. Each participant will draw one slip of paper from a container. Tell participants that when you say "now," each person must make the noise of the animal written on her slip of paper. While making their noises, participants must look and listen for those making the same animal noise they are making. These people are their group members.

\section{LEARNING PRINCIPLES AND PRACTICES TO KEEP IN MIND}

The box below is a reminder of some important principles and practices of youth learning to keep in mind as you lead each session. Remember that you, the trainer do not have all the answers. The participants come to the learning sessions with a great deal of experience and have many things to add. It is important that all participants (including you) teach and learn.

\section{IMPORTANT PRINCIPLES TO REMEMBER}

- Create a safe learning environment.

- Give feedback to the participants and praise them for their efforts.

- Think about ways of making the topic useful to all participants present.

- Let the participants know that you are a learner with them, as well as a leader and a mentor.

- Promote conversations and questions that allow young people to explore and clarify their values as they develop a sense of self.

- Use a variety of activities that are appropriate for different maturity levels to cover young people's many developmental stages.

- Make the learning relevant to young people's current situation. Be cautious about asking them to project far into the future.

- Anticipate that young people may have limited experience with a topic. Simulations or stories may have to substitute for real-life experience.

- Be sure that throughout the session there is an opportunity for thinking, acting, and feeling.

- Include current media to ensure relevance of the topic and to promote discussion.

- Engage participants' families and communities to connect with the program, understand its content, and support the young people in changing behaviors and meeting goals.

- Encourage humor and use interactive games so that the training is dynamic and fun! 


\section{DREAM BIG! KWACHA FOR OUR FUTURE: LEARNING SESSIONS AT A GLANCE}

The goal of these sessions is to help girls manage their money effectively. They will be delivered as part of AGEP along with other sessions on health and life skills. See the proposed order of integrating the financial education sessions into the overall AGEP curriculum above.

The following table presents the module's learning sessions and their purposes.

\begin{tabular}{|c|c|}
\hline SESSION TITLE & \multirow[t]{2}{*}{ PURPOSE OF THE SESSION } \\
\hline SECTION 1: DREAM BIG & \\
\hline 1. Dream & $\begin{array}{l}\text { - Discuss participants' dreams for the future } \\
\text { - Analyze the strengths, weaknesses, opportunities, and } \\
\text { threats for Chikondi through her story } \\
\text { - Analyze the strengths, weaknesses, opportunities and } \\
\text { strengths to achieving future dreams using a SWOT } \\
\text { (Strength, Weakness, Opportunity, Threat) diagram }\end{array}$ \\
\hline \multicolumn{2}{|c|}{ SECTION 2: THE EIGHT STEPS FOR SAVING AND EARNING MONEY } \\
\hline 2. Why Save? & $\begin{array}{l}\text { - Introduce and recite the "Eight Steps for Savings" } \\
\text { - Identify and compare the saving goals of adults and } \\
\text { young people } \\
\text { - Determine personal savings priorities }\end{array}$ \\
\hline $\begin{array}{l}\text { 3. Choose a Savings } \\
\text { Goal }\end{array}$ & $\begin{array}{l}\text { - Recite the "Eight Steps for Savings" and three catego- } \\
\text { ries of saving from Session } 2 \\
\text { - Analyze Monica's savings goals } \\
\text { - Participants describe their own saving goals }\end{array}$ \\
\hline 4. Make a Savings Plan & $\begin{array}{l}\text { - Calculate the time and money needed to achieve a sav- } \\
\text { ings goal } \\
\text { - Develop a savings plan for a savings goal } \\
\text { - Discuss the savings plan of a volunteer in the class }\end{array}$ \\
\hline $\begin{array}{l}\text { 5. Learning About } \\
\text { Banks }\end{array}$ & $\begin{array}{l}\text { - Learn what a bank is and discuss common myths about } \\
\text { banks }\end{array}$ \\
\hline $\begin{array}{l}\text { 6xploring Options } \\
\text { for Earning Money }\end{array}$ & $\begin{array}{l}\text { - Identify various options for increasing money earned } \\
\text { - Explore ways to improve existing income-generating } \\
\text { activities } \\
\text { - Consider new ways to earn money }\end{array}$ \\
\hline $\begin{array}{l}\text { 7. Girls' Money and the } \\
\text { Risky Income Cycle }\end{array}$ & $\begin{array}{l}\text { - Explore how adolescent girls in their community make } \\
\text { and spend money } \\
\text { - Discuss the risks and risk-reduction strategies of girls' } \\
\text { income cycle }\end{array}$ \\
\hline
\end{tabular}

\begin{tabular}{|c|c|c|}
\hline & $\begin{array}{l}\text { Know the Difference } \\
\text { Between Needs and } \\
\text { Wants }\end{array}$ & $\begin{array}{l}\text { - Distinguish between needs and wants } \\
\text { - Describe Bwalya and Mutinta's needs and wants using a } \\
\text { story }\end{array}$ \\
\hline & Control Spending & $\begin{array}{l}\text { - Understand the idea of making spending priorities } \\
\text { - Practice making a personal budget }\end{array}$ \\
\hline 10. & $\begin{array}{l}\text { Think About the } \\
\text { Future: Money In } \\
\text { and Money Out }\end{array}$ & $\begin{array}{l}\text { - Report the ways in which a girl (Mwaka) plans ahead for } \\
\text { her income and expenses } \\
\text { - Describe the behavior of someone who does not plan ahead }\end{array}$ \\
\hline & Save Regularly & $\begin{array}{l}\text { - Determine whether statements about savings behavior } \\
\text { are true or false } \\
\text { - Evaluate the savings behavior of two cousins }\end{array}$ \\
\hline 12. & Save in a Safe Place & $\begin{array}{l}\text { - Identify and list the advantages and disadvantages of } \\
\text { saving at a bank } \\
\text { - Identify and list the advantages and disadvantages of } \\
\text { saving at home } \\
\text { - Compare saving at home and saving at a bank }\end{array}$ \\
\hline 13. & $\begin{array}{l}\text { Dealing with } \\
\text { Setbacks in Saving }\end{array}$ & $\begin{array}{l}\text { - Explore the challenges and possible setbacks in saving } \\
\text { - Understand difficulties encountered when plans don't go } \\
\text { as planned } \\
\text { - Understand how to deal with setbacks in saving }\end{array}$ \\
\hline \multicolumn{3}{|c|}{ SECTION 3: TALK ABOUT MONEY } \\
\hline & $\begin{array}{l}\text { Your Own Money } \\
\text { vs. Someone Else's } \\
\text { Money }\end{array}$ & $\begin{array}{l}\text { - Differentiate between one's own money and borrowed } \\
\text { money } \\
\text { - Identify characteristics of borrowed money } \\
\text { - Understand the importance of being in control over your } \\
\text { own money }\end{array}$ \\
\hline 15. & $\begin{array}{l}\text { Talking About } \\
\text { Money }\end{array}$ & $\begin{array}{l}\text { - List who they talk about money with and what they talk } \\
\text { about } \\
\text { - Describe the possible outcomes of discussing money: }\end{array}$ \\
\hline 16. & $\begin{array}{l}\text { The DOs and DON'Ts } \\
\text { of Talking About } \\
\text { Money }\end{array}$ & $\begin{array}{l}\text { - List reasons for communication breakdowns } \\
\text { - Identify the "dos" and "don'ts" of good communication } \\
\text { on money }\end{array}$ \\
\hline 17. & $\begin{array}{l}\text { Resolving Conflicts } \\
\text { About Money }\end{array}$ & $\begin{array}{l}\text { - Recognize the DOs and DON'Ts of good communication } \\
\text { in a real-life experience } \\
\text { - Identify good communication skills in a sample dialogue }\end{array}$ \\
\hline 18. & $\begin{array}{l}\text { Role play Resolving } \\
\text { Conflicts }\end{array}$ & $\begin{array}{l}\text { - Practice using communication skills to resolve } \\
\text { conflicts about money through role plays } \\
\text { - Identify more than one solution to sample conflicts }\end{array}$ \\
\hline \multicolumn{3}{|c|}{ SECTION 4: CONCLUSION AND REFLECTION } \\
\hline 19. & $\begin{array}{l}\text { Our Journey to } \\
\text { Good Money } \\
\text { Management }\end{array}$ & $\begin{array}{l}\text { - Reflect on dreams for the future } \\
\text { - Revisit key topics from the FE curriculum } \\
\text { - Celebrated the completion of the FE course }\end{array}$ \\
\hline
\end{tabular}




\section{FEATURES OF THE LEARNING SESSIONS}

Each learning session in this module begins with a summary page that contains the following:

- Objectives-list of actions that the activities in the learning session are designed to accomplish.

- Materials/Preparations-list of materials that the trainer must prepare before the activity can be presented. Review this information carefully.

$\checkmark$ Flipcharts are listed and incorporated into the activity in which they occur.

$\checkmark$ Handouts needed for each activity are found in the sessions themselves, and in the Toolkit at the end of this resource book.

- Time-the estimated time needed to implement all of the activities designed for the learning session.

- Activities-a list of activities or steps needed to complete the learning session. Detailed instructions for the learning activities that will help participants learn and work with the concepts of the session are given. The titles capture the process to be used and the content to be covered. The order in which they should be implemented is also given: please follow the steps as outlined. However, you should use your own words to explain each point.

Special features for the trainer to note include the following:

\section{highlights specific open questions to ask participants [in bold}

type], or further explanations or instructions to give them

[Square brackets] = the "correct" answer to expect from a technical question

(Parenthesis) $=$ additional instructions or information

\section{TERMS AND DEFINITIONS}

A challenge of working with girls with low levels of financial literacy is helping them to understand the important terms in money management. The following bold terms are used in the learning sessions, and their explanations and definitions are provided for your reference.

Advantage: Any condition, situation, or opportunity that helps someone to succeed or benefit.
Budget: A written plan that estimates future income, expenses, and savings.

Conflict: A situation when two or more people fight or disagree.

Deficit: When there is not enough money to cover all costs at the end of a budget period.

Disadvantage: A negative condition or situation that can cause someone harm.

Expenses: Money out-this can be money spent for any purpose.

Goal: Something someone wants to achieve in the future-perhaps in school, perhaps related to family, perhaps related to work. A goal might be to visit a relative who lives in another place, or to learn a new skill, like sewing or typing.

Short-term goal: A goal that can be achieved in a relatively short period of time, such as 1-2 months.

Long-term goal: A goal that will take a long period of time to achieve, like 1-2 years.

Income: Money in-this could be regular or irregular, from a job, or even a gift.

Loan: A sum of money that is borrowed and that must be paid back.

Needs: A basic necessity that you cannot live without-like food, water, and a place to live.

Outcome: The result of something

Saving: Putting money aside for future use.

Savings Plan: A written guide for how to manage and save money to achieve a savings goal.

Self-Employment: A self-employed person operates his or her own business or job, and makes all of the necessary decisions related to the business-such as working hours, investment, products and services, etc.

Surplus: Money remaining or left over (at the end of a budget period-like a week or month).

Wants: Something that is desired, but not necessary for daily survival-such as sweets, makeup, hair extensions, etc. 
三DREAM BIG! 三 


\section{1) Dream Big!}

OBJECTIVES
By the end of this session, participants
will have:
- Discussed their dreams for the
future.
- Analyzed the strengths, weaknesses,
opportunities and threats for
Chikondi through her story.
- Analyzed the strengths, weaknesses,
opportunities and threats to
achieving future dreams using
a SWOT (Strength, Weakness,
Opportunity, Threat) chart.
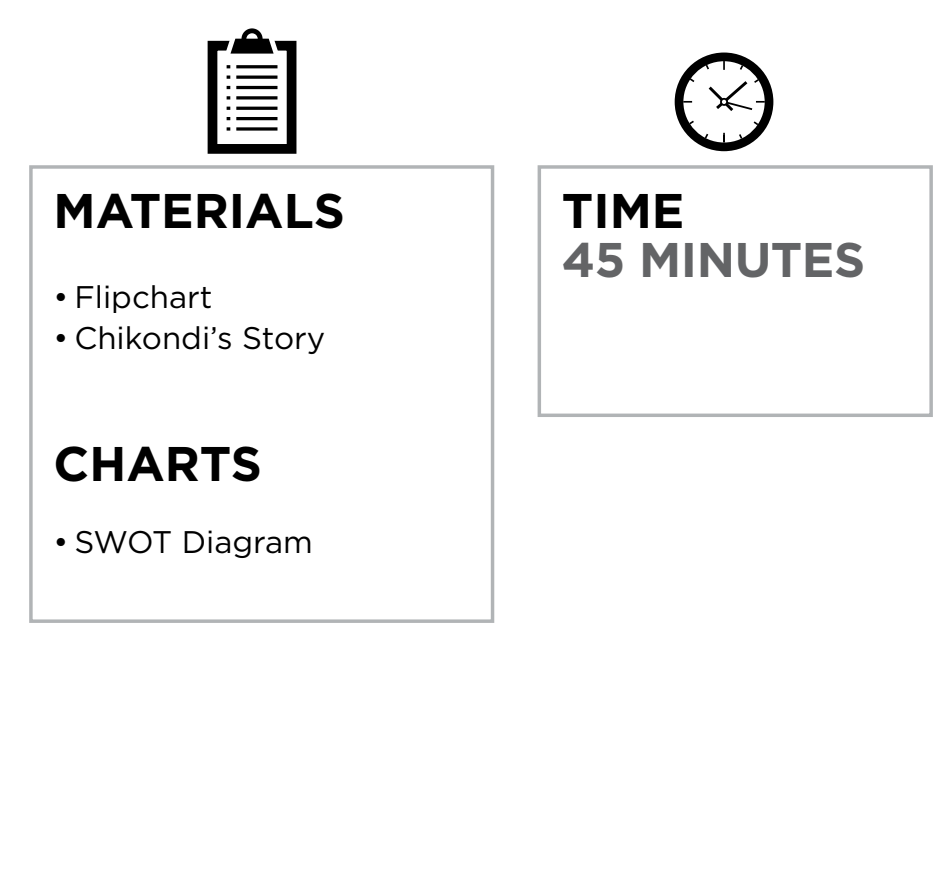
$\square$ ACTIVITIES
1. What are your dreams? (10 minutes)
2. Chikondi's story (15 minutes)
3. The SWOT chart (20 minutes)




\section{activity 1}

\section{WHAT ARE YOUR DREAMS?}

\section{(10 MINUTES)}

Welcome girls to the learning sessions on financial education.

\section{Explain:}

5 We are meeting together in our Safe Spaces group to support each other, and to learn about how to make good decisions about our lives. Now, we are going to start learning about how to plan for and make good use of our money, too. This is because money is also important when it comes to making choices. This type of learning or training is called "financial education." (Amasambililo ya pa ndalama/Mapunziso ya ndrama)-and it is all about using money wisely to meet our daily needs and help reach some of our dreams.

Say:

I want you to think about your dreams. Close your eyes for just a moment, and think about how old you are now. How old will you be in five years time? Think about yourself five years from now when you are older.

Where are you living? What are you doing? What goals or plans have you achieved?

Now, I want you to think about one specific dream you want to achieve in five years' time. Got it?
Make sure that all girls have thought of at least one dream. Then, ask 3-4 volunteers to share their dreams.

Then make the connection between the girls' "dreams" and financial education.

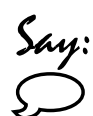

Now that we have all thought about some of our dreams I want everyone to stand up and clap if reaching your dream will involve having some money.

As we can see, most of our dreams require some money to be reached. So we need to be wise about how we earn, spend, and save our money so that our dreams can come true. 


\section{activity 2}

\section{CHIKONDI'S STORY}

\section{(15 MINUTES)}

\section{Say:}

If we want to achieve our dreams, we have to plan and prepare using our good judgment-including how we manage our money. I am going to tell you the story of a childhood friend, Chikondi.

Let's listen to the story of Chikondi. While you listen, think about how she prepares for her future, and what some of the things are, both inside her and around her, that either support or block her as she tries to achieve her dreams.

Read the story of Chikondi, found on the next page. Quickly de-brief the story:

\section{Ask:}

What happened in this story? Who can tell me in her own words?

\section{What is Chikondi's dream?}

[To become a dancer.]

Next introduce the idea of Strengths, Weaknesses, Opportunities, and Threats. If you have a flipchart or blackboard, draw an outline of a girl to refer to as you ask the following questions, and then note down girls responses under the headings Strengths, Weaknesses, Opportunities, Threats (or you can just show them the picture found at the end of this session).

\section{Say:}

We all have inside us and around us things that either support or block us from reaching our dreams. Let's use Chikondi's story to try and understand what this means, and why it is important to think about:

- What were some of the Strengths-or supports inside her (ifimukosha mukati kakwe)-that helped Chikondi achieve her dream?

[She is helpful and cares for her family; she is hardworking and knows how to earn money; she is a good dancer and she is dedicated to practicing.]

\section{- What were some of Chikondi's}

Weaknesses-or blocks inside her

(Ifichingilila mukati kakwe) that got in the way of her dream?

[She is stubborn, and made a bad decision to drop out of school; she does not always manage her money well.]
- What were the Opportunities-or supports around her-that could help Chikondi achieve her dream?

[She has a loving mother who helped her and looked for her when she went missing; her school fees were paid, and so were those of her sisters; there is a youth center in her community that teaches dance and supports a dancing group.]

\section{- What were some of the Threats-or} potential blocks around her-that made her dream harder to reach?

[Her family is struggling with money; her mother does not want her to become a dancer, she has some friends who give her bad advice, indecent dancing clubs offer her "easy money."] 


\section{CHIKONDI'S STORY}

Chikondi is 17 years old, and the oldest in her family. She stays with her mother and her three sisters in a two-room house in (Give an example of a community name in your area). Her mother struggles to pay rent and also to feed her girls but she is proud of Chikondi since she is so helpful with housework. Chikondi even earns some money to help the family by washing clothes for an elderly neighbor and by selling sweets to other pupils at her school.

Luckily, Chikondi and her sisters are smart, and Chikondi's mother was helped by the church with scholarships. All four of her children got sponsors who pay school fees for them in a nearby day school-though Chikondi has to use some of the money she earns to buy school supplies.

As a young girl Chikondi always told her mother that she wanted to be a dancer, just like the Famous Liseli sisters. Her mother always tells her: "that is not a future job for a person I gave birth to!" So every time Chikondi would run to the dancing grounds and practice dancing without her mother's knowledge. She also used some of the money she earned to buy refreshments for her friends at the dancing grounds-even if it meant not being able to buy all of the school supplies she needed, or saving any money for the dancer's costume she wanted to buy.

When Chikondi reached Grade 9, she dropped out of school. Even when her mother pleaded with her to stay in school and reminded her about her sponsorship she refused. One of her friends from the dancing group said he knew about a way she could make "easy money" and tricked her into leaving home and becoming an indecent club dancer. Chikondi's mum promised not to give up on her daughter so she visited a youth center and talked to the staff who agreed to help her find Chikondi and also provide counseling services. Finally she came back home and they trained her in dancing and acting at the youth center. Chikondi is now one of the prominent dancers in a popular dancing group that is sponsored by the youth center. She even makes money both performing at local celebrations and festivals. 


\section{activity 3}

\section{THE SWOT DIAGRAM}

(20 MINUTES)

\section{Say:}

As we have just explored through Chikondi's story, if we want to reach our dreams we have to think carefully about the things inside us, and the things around us, that can either support us or block us.

In fact, we can all use a picture like this (show SWOT Diagram on a flipchart, blackboard or in your Dream Big Curriculum) to think carefully about the things inside of us and outside of us that can support or block us as we try to achieve our dreams.

I want you to continue to think about the dream you just chose earlier in today's session-and I want you to work with a partner to try and identify some of the Strengths, Weaknesses, Opportunities, and Threats that might impact you reaching your dream.

Make sure all the girls have a partner-and then go through the following questions step-by-step, giving the girls time to share a few ideas with each other (and referring to your SWOT Diagram at each step).

Step \#1. Let's start by speaking to our partner about some of our Strengths-or things I have inside me that might help me to achieve my dream. Strengths are all the things you are good at or things that you have within you that could help you achieve your goals. They could be part of your personality, skills that you have, or things that you are good at.

Step \#2. Now, even though this might be hard to do at first, let's speak to our partner about some of our Weaknesses-or the things inside me that might block me from reaching my dream. Weaknesses are things about you that you may need to work on-or improve-to achieve your dream. For example, you may not be good at time management, do not know how to use a computer very well, or it may even be that you are poor at skinning animals or preparing traditional drinks.

Step \#3. Next, let's share a few examples of our Opportunities-or some of the things around me that might help me to achieve my dream. An opportunity could be something like computer classes being offered next month at a discount. Or, you have seen that there is a need for more tailors in your neighborhood. This means that you could take a computer class for a cheaper price, or that you could make money as a tailor, for example.

Step \#4, Finally, and again this might be hard let's speak to our partner about some of our Threats-or things around me that might block me from reaching my dream. This is anything outside you-in your neighborhood, at your school, at your work, in your family-that is a challenge. If you have a small shop, a threat to your success is if there are many other people selling the same things near you. That means that you might not have good business. Another example that girls have mentioned in other classes is an unplanned pregnancy. If you become pregnant or have a child before you are ready, you might have to stop study ing. This means that you might not realize your dream of finishing secondary school.

After going through each of these four steps, invite girls to ask any questions they might have about using a SWOT Diagram, and let them know that it is a skill they will continue to use in future sessions.

\section{Say:}

It is important that when you make plans to achieve your dreams you think about what will help you and what might make it harder for you. That way you can take advantage of the good things and plan how to work with the things that might be hard. Over the next several sessions we'll talk a lot more about your dreams, plans, and goals for the future, especially those related to money, so we can all achieve those dreams. 


\section{THE SWOT DIAGRAM}

Things I know about myself and the space around me
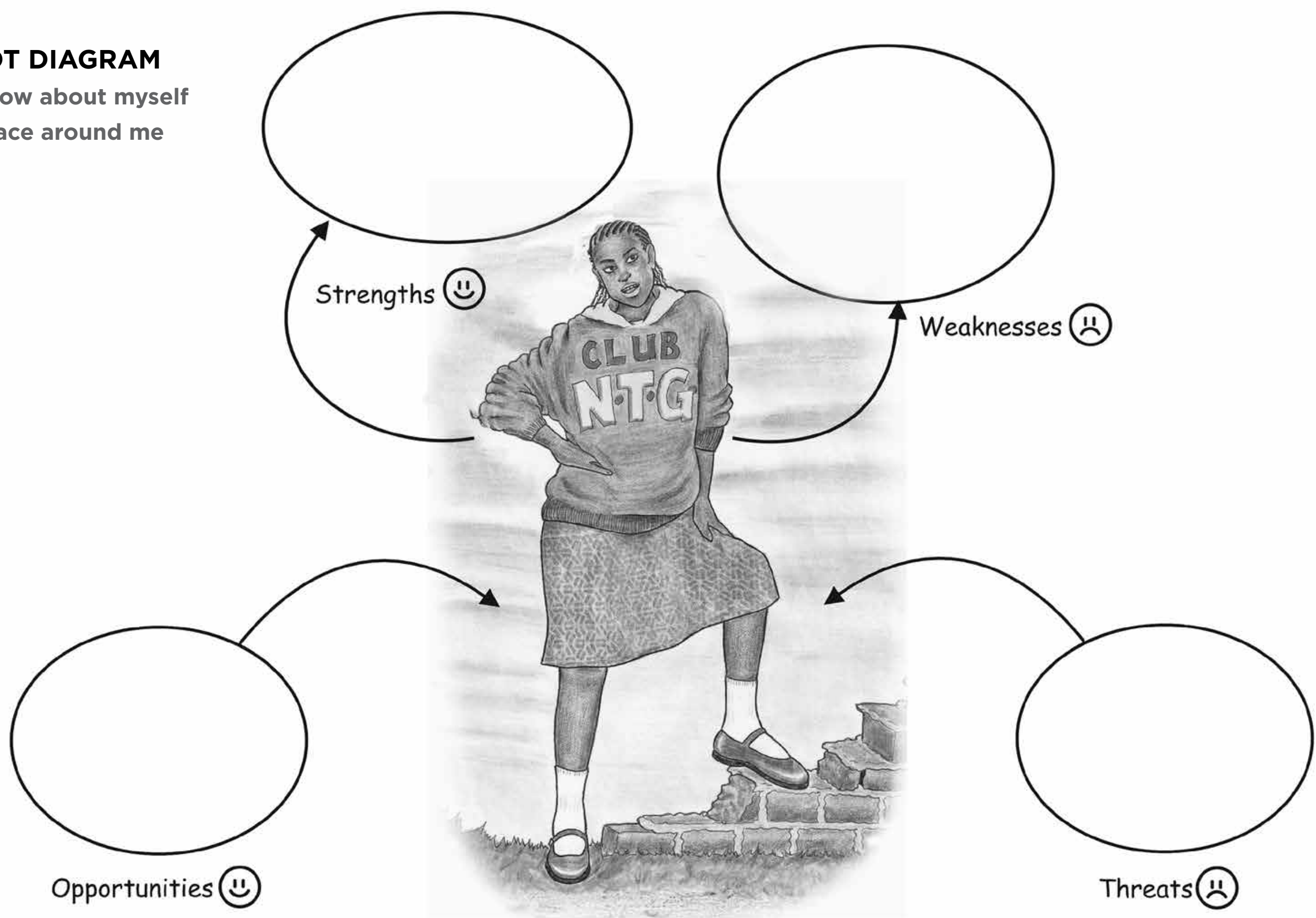


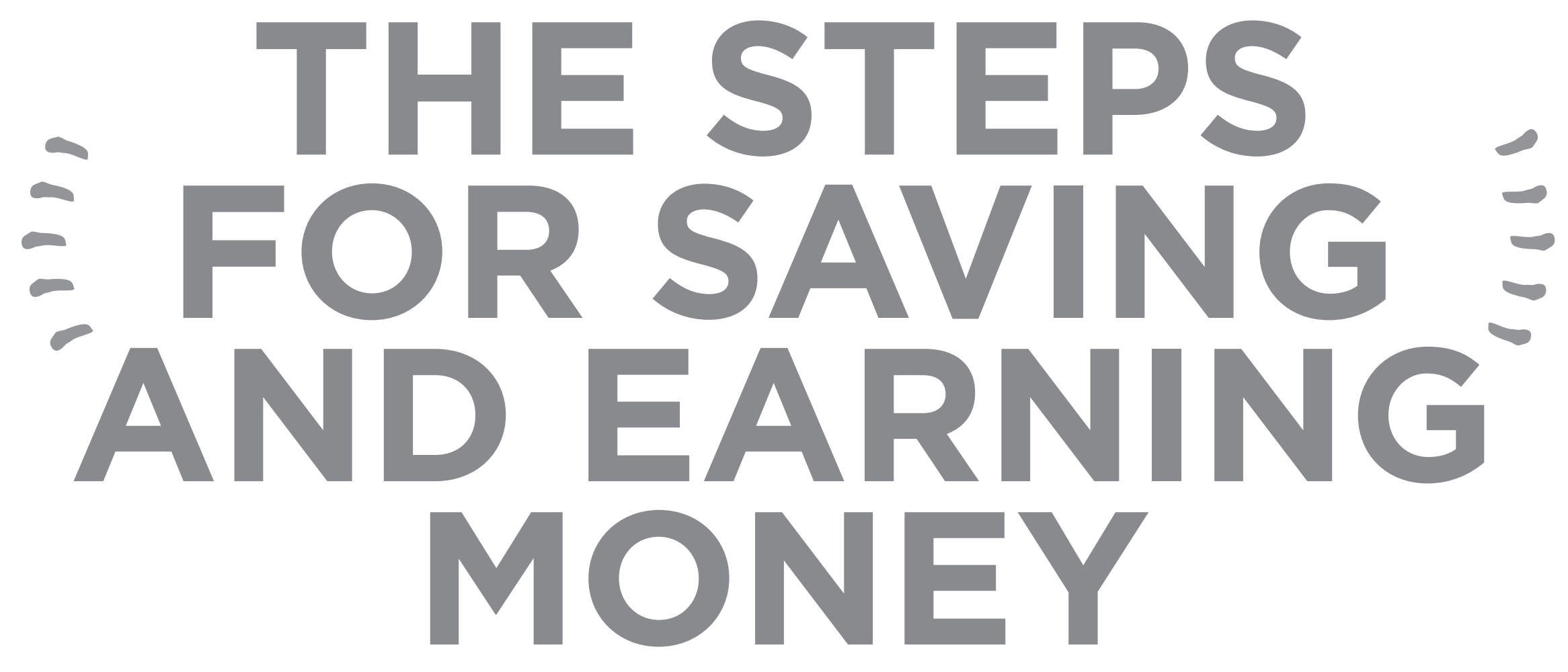


2) Why Save?

OBJECTIVES
By the end of this session, participants
will have:
- Recited the "Eight Steps for Savings."
- Identified and compared the savings
goals of adults and young people.
- Determined their own savings
priorities.

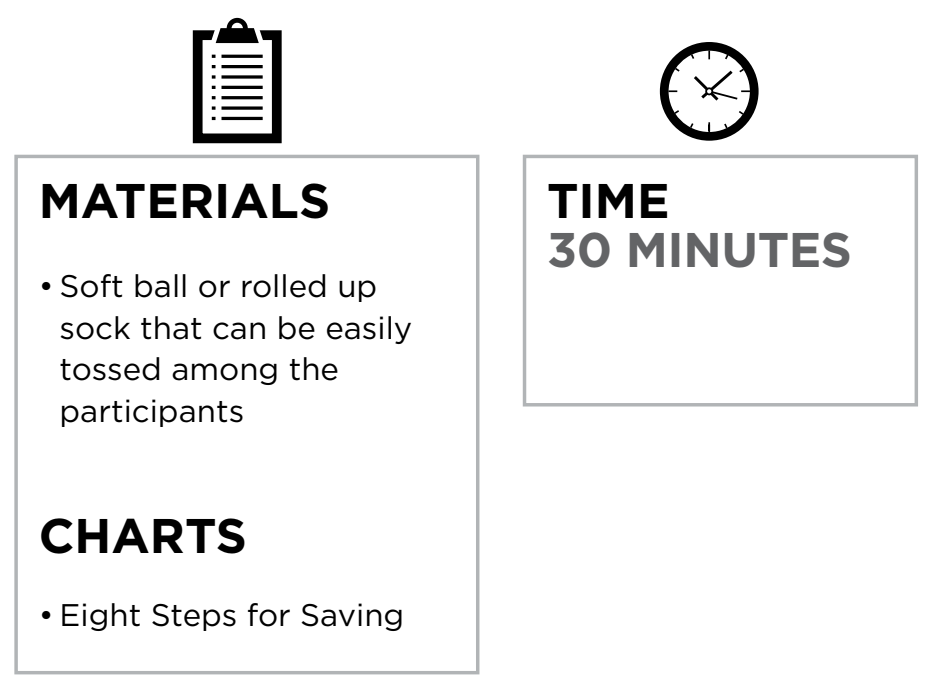

ACTIVITIES
1. The "Eight Steps for
Savings"-7 minutes
2. Why do we save? Pass
the "ball"-8 minutes
3. Many reasons to save:
What are your priorities?
-15 minutes


activity 1

\section{THE “EIGHT STEPS FOR SAVINGS"}

\author{
(7 MINUTES)
}

ADVANCE PREPARATION: Draw a map of the community. Try to do it in a creative way. It does not have to be a literal map of the community but can be a representation through symbols, such as a town represented as a flower with different petals.

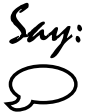

Today we start the first learning session in our financial education program. Our goal is to learn one important way of managing our money. We will start by talking about putting money aside because it is the key to being wise about money. We call "putting money aside" saving. Later on, we will also talk about other things related to money-like how to talk to other people about money and different ways to earn money.

So let's start with a short activity to find out a little more about what managing money really means.

(NOTE TO TRAINER: For the game below, make sure to keep the group moving. If you stop to discuss each statement, the time needed for the activity will increase greatly. Keep the group moving to keep the energy of the game!)

\section{Explain:}

I am going to say a series of statements and ask you to stand up for each one that is true for you. Stand up if you:
- Walked here today

- Are wearing green

- Never saved money before AGEP

- Like to spend money

- Know how much you spent on food last

week

- Wish you had more money

- Are saving for something specific you want

- Think saving is important

- Think saving money is difficult

Ask:

$\int$ For those of you who think that saving is important, why do you think so?

[Helps you use your money better, helps you depend less on other people, makes you feel secure when you have a problem and need money, helps you to plan for the future and achieve those plans.]

\section{Why is saving money difficult?}

[Do not have regular income, do not have any extra money, give any leftover money to parents for household expenses, spend extra money on things like sweets or make-up, do not have a safe place to keep money aside.]

\section{What would make you want to save money?}

[Take care of personal needs/wants, avoid depending on other people, be able to make own decisions, help out family in household needs.]

\section{What would make you not want to save money?}

[lt is not safe to save, you can lose your money, money is too little to save, don't know how to save.]

Explain:

Managing money involves all these things: - saving money

- spending money

- planning how you will spend your money, and - keeping track of how you spend your money. Since most of us do not have enough money to pay for everything we need and want, we have to make choices about what we will buy and what we won't. We try to save for things we will want in the future. We figure out how to stretch our money to cover the necessary expenses we face. It can be hard.

Show the "Eight Steps for Savings Chart" or refer to sample on the next page.

\section{Explain:}

In the next few sessions, we will focus on the value of saving, and learn things we can do to help us save. We call these the "Eight Steps for Savings."

As you state the Steps for Savings, assign each one to a group of girls, so that every girl has an assigned Step. Then, later, when you want to review the Steps, you can ask girls to recite them back! 


\section{(1) (1) EIGHT STEPS FOR SAVINGS}

100

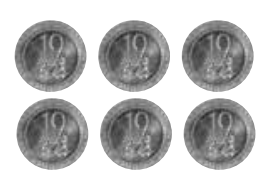

1. Choose a Savings Goal

2. Make a Savings Plan

3. Know the Difference Between Needs and Wants

4. Control Spending

5. Think About the Future: Money In and Money Out

6. Save Regularly

7. Save in a Safe Place

8. Deal with Setbacks in Saving 


\section{activity 2}

\section{WHY DO WE SAVE? PASS THE "BALL"}

(8 MINUTES)

\section{Ask participants to stand and form a circle.}

First, explain how "pass the ball" works. You (the trainer) will say a sentence that is unfinished and throw the "ball" (ball of string, rolled up sock, or balled up paper) to someone in the circle. That girl has to repeat the beginning part of the sentence you have started and "answer" it, or complete the sentence.

\section{For example:}

\section{FACILITATOR/}

MENTOR: Girls my age save money to

GIRL: Girls my age save money to buy a new shirt.

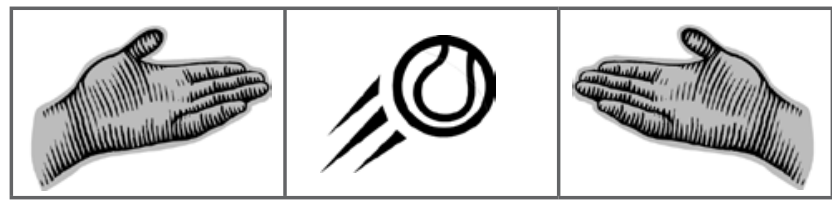

After answering, the first girl will toss the ball to another girl in the circle who has to repeat the same sentence beginning and provide her own ending.
This activity will be done in three rounds with the following three sentences. You decide when to move on to the next sentence. When the participants start to appear bored or tired with one sentence, move on to the next. You do not need to wait until everyone has provided an ending to each sentence. It is better to keep things moving at a lively pace!

Use the following three sentences:

Girls my age save to

Boys my age save to

Adults often save to

After the three rounds, summarize what you have heard. Highlight the differences and similarities between what girls, boys, and adults save for. 


\section{activity 3}

\section{MANY REASONS TO SAVE: WHAT ARE YOUR PRIORITIES}

(15 MINUTES)

\section{Explain:}

You have named many different reasons to save. Most will relate to one of the following "main reasons" (or "categories") for saving.

1. The first main reason is: personal or family use, which can include food, clothes, rent, or snacks.

\section{What are other examples of "personal or} family use"?

[Hair maintenance, sanitary towels, lotion, gas for lights, etc.]

2. The second main reason is: emergencies, those unexpected events that we need to deal with right away. Some examples are illness, accidents, or natural disasters.

\section{What other emergencies can we save for?}

[theft, fire, parent loses a job, poor harvest, etc.]

3. The third main reason is:

future opportunities, like those ideas some of you have for the future. We can save to meet these goals. We might save money for school fees, to get training in a skill or trade, for the next planting season, to move into our own house/room, or to start a business.

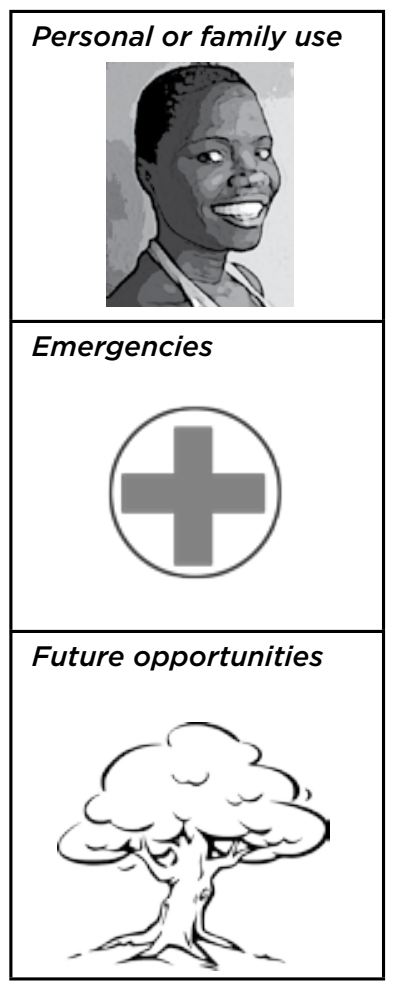

What other future opportunities can we save for?

[Education, wedding, training or skills school, children's educations, a house or land, a lump sum of money to start a business, etc.]
While participants are still standing, assign a place for each of these three main reasons (if you are inside, you can use a corner, the door, a window; if you are outside, select or mark three distinct spots-for example, near a tree, bush or rock-close by). When you have pointed out the three places:

Say:

Your job is to decide which of these main reasons, or "categories" of reasons to save is the highest priority for you. Choose one, and go stand in the location assigned the category you have selected as your most important reason to save. You have 15 seconds to make your choice and move!

Once everyone has moved to the place that marks the savings category of their choice,

Say:<smiles>C1CC2CCCC(C1)C2</smiles>

Now, spend two minutes sharing with the others who have chosen the same priority why you think this reason to save is the most important.

(NOTE: If all the girls move to one or two of the categories, you will have to ask for volunteers to "choose" the one that has not been selected and ask them to move to the spot that does not have enough people.) (activity 3 continued on next page) 


\section{activity 3 (continued)}

Select a volunteer from each group to explain to everyone why they chose the category they did.

\section{Ask the other two groups:}

\section{Do you agree? Why or why not?}

Start a discussion-but don't let it become a shouting match or fight. Make sure that each group has an opportunity to explain why their selected category is a high priority. When the discussion is over, ask participants to sit down.

\section{Explain:}

You might have guessed by now that there is no wrong answer for which of these categories is the most important. They are all good reasons to save, and the importance depends on the individual's or family's needs and wants. The level of importance might also change over time. But in reality it can be difficult to save for all three. Sometimes you have to decide what is most important to you.

\section{Ask:}

What happens when a girl needs money for these things, like personal needs or to deal with an emergency, but she does not have money of her own?
Listen to girls' answers to the question. The answers can vary widely from not buying items/going hungry to do work to earn money to getting money from other people.

When they are done,

\section{Explain the following:}

$S$ Sometimes when girls need money to buy personal items, help their family with food or rent, or manage an emergency that might come up, if they do not have their own money saved up that they can use, they find other ways to get that money. A lot of times, that means going to different men to ask for money. Depending on men for money can lead to situations where the men expect sex in return, whether right then and there, or at a later time. This can be a risky situation for your health and your safety since it might be hard to say no when you feel like you owe the person something. So, one important reason to save is that when these needs come up-personal items, future use, or emergencies-you have your own money to use instead of putting yourself in a potentially risky situation to get money. We will talk more about this in the coming sessions. 
3) Choose a Savings Goal

\begin{tabular}{|l|} 
OBJECTIVES \\
By the end of this session, participants \\
will have: \\
- Recited the "Eight Steps" and three \\
categories of savings from Session 1. \\
- Analyzed Monica's savings goals. \\
- Described their own savings goals. \\
\end{tabular}

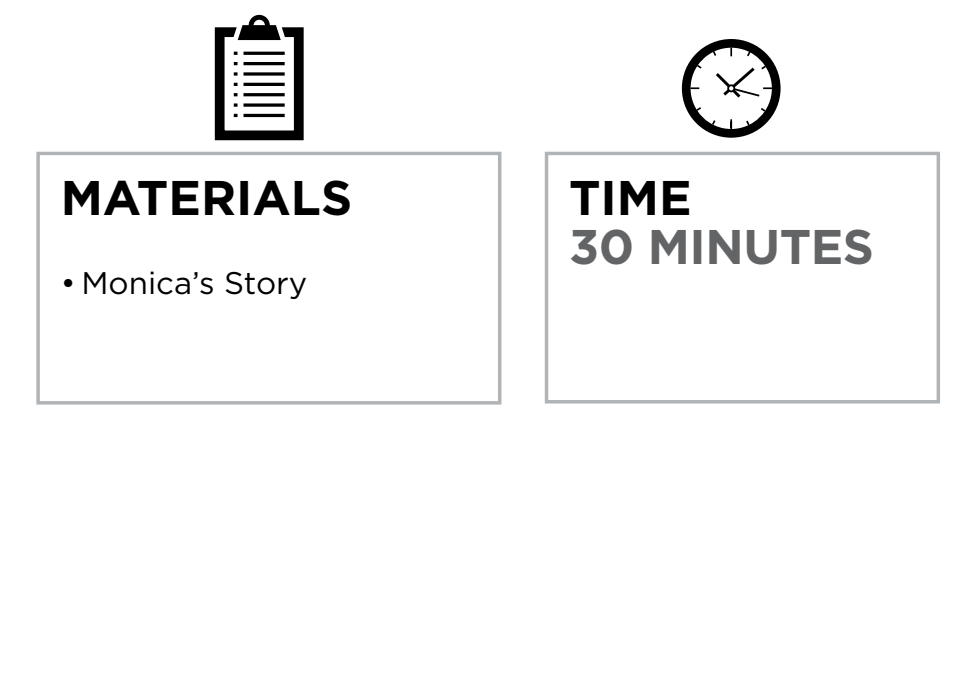

ACTIVITIES
1. Review the "Eight Steps for
Savings" -5 minutes
2. What is a goal? -5 minutes
3. What are Monica's
goals? -10 minutes
4. What are your savings
goals? -10 minutes




\section{activity 1}

\section{REVIEW THE "EIGHT STEPS FOR SAVINGS"}

(5 MINUTES)

\section{Explain:}

We have talked together in our savings group about why saving is a good thing.

Review the three categories of savings-Personal or Family Use, Emergencies, Future Opportunitiesfrom Session 2, Activity 2. If girls do not remember, remind them as a short review.

\section{Ask:}

What are three categories of saving from the last meeting?

[Personal or family use, emergencies, future opportunities.]

Say:

As we know, savings can help us start a business or respond to an emergency or buy something we really want. We also know how hard saving money can be. To make it easier, we are going to talk about eight steps we can use to help us save.

If you remember, I assigned you each a step to remember in the first session. We will talk about one strategy each week until we've reviewed them all!
Ask girls to recite the Steps they were put in charge of during the last week. If girls cannot remember, remind them, if possible, show the picture cards. Make sure all the steps below are recited.

\section{EIGHT STEPS FOR SAVINGS}

1. Choose a Savings Goal

2. Make a Savings Plan

3. Know the Difference Between Needs and Wants

4. Control Spending

5. Think About the Future: Money In and Money Out

6. Save Regularly

7. Save in a Safe Place

8. Deal with Setbacks in Saving

\section{activity 2}

\section{WHAT IS A GOAL?}

(5 MINUTES)

\section{Ask}

Remember your dreams about the future from the beginning of our sessions in financial education? What are some of your dreams?

After girls have given examples of their dreams,

\section{Explain:}

These dreams about the future can be called goals. A goal is something you want to achieve in the future-perhaps in school, perhaps related to your family, perhaps in your work. A goal might be to visit a relative who lives in another place, or to learn a new skill, like sewing or computer skills.

Goals that involve what we want to do with the money we save are savings goals. 


\title{
activity 3
}

\section{WHAT ARE MONICA'S GOALS?}

\author{
(10 MINUTES)
}

\section{Explain:}

I l am going to read a short story about a gir your age. Her name is Monica. As you listen to the story, pick out her goals on money.

When you have finished reading the story,

Ask:

\section{What are Monica's savings goals?}

[Transportation to her sister's town, a gift for her sister's baby, money to start a small business.]

\section{Which of her savings goals can be met} within a few weeks?

[Transportation money, the baby gift]

Which savings goal will take a longer time? [Money for a business.]

What can Monica do to meet her goals? [Ask for many different solutions from participants such as different jobs she could do, expenses she could cut down on, etc.]

\section{MONICA'S STORY}

Monica is 18 years old and lives with her mother and younger brother. Her older sister, Mary, is married and lives in another town, two hours away. Mary just had a baby girl and Monica is eager to visit, to spend time with the baby and help her sister.

Monica will need money for transportation and a small gift for the baby. A cute little dress would be perfect! But she can't take money from her savings account for this trip because she is saving that money to start her own business. Monica's dream is to start a small business selling second-hand clothes (salaula). She hopes, her neighbor will employ her to work extra days in her salon so she can get the money she needs for her trip.

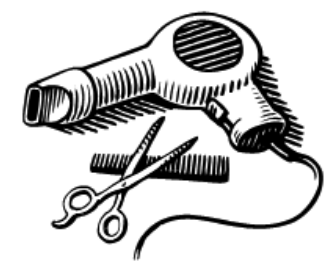




\section{activity 4}

\section{WHAT ARE YOUR SAVINGS GOALS?}

(10 MINUTES)

\section{Explain:}

Like Monica, many of you hope to achieve something by saving.

First, close your eyes and think of one savings goal you have that you can achieve in a relatively short time-within the next 1-2 months. Got it? That is your first goal. Okay-keep it in your mind for just a moment!

Now, think about a different goal, something you want to be able to purchase that will probably take you a little longer-like 1-2 years-to save for.

Turn to your neighbor and share with each other your two goals.

Check girls' understanding by asking for some examples of their first and second savings goals. After asking 3-4 volunteers,

\section{Explain:}

The first savings goal you just thought of-the goal that will take you just a few months-can be called a short-term goal. You can achieve short-term goals in a relatively short amount of time.
The second savings goal you just thought of-the one that will take a year, or more!is a long-term goal. This goal is like a big dream that you can achieve some time in Ask:

the future.

How can having a savings goal help you to save?

[When you are saving for something that you really want, or that is really important to you, you are motivated to save and have discipline to control your spending.]
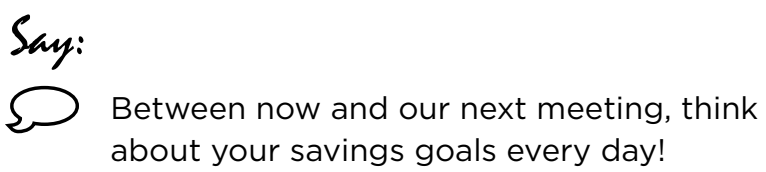
4) Make a Savings Plan

OBJECTIVES
By the end of this session, participants
will have:
- Calculated the time and money
needed to achieve a savings goal
using play money.
- Developed a savings plan for a
savings goal.
- Discussed the savings plan of a
volunteer in the class.

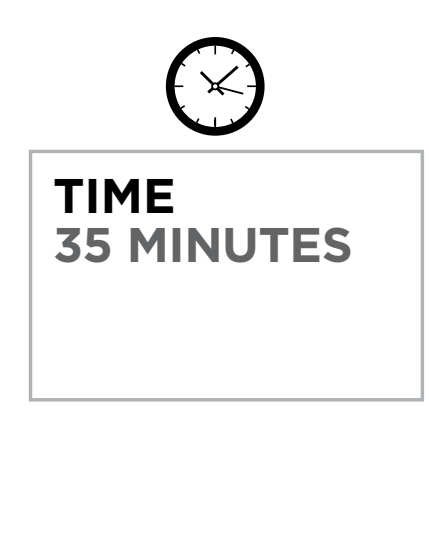




\section{activity 1}

\section{REVIEW SAVINGS GOALS}

(5 MINUTES)

\section{Ask:}

\section{What is a savings goal?}

[A savings goal is something you save money for. It can be something big or small you want to buy, or a training program you want to register for, or a trip you want to take.]

What are some of your "small" savings goals?

What are some of your "big" savings goals?

\section{activity 2}

\section{MAKE A SAVINGS PLAN}

(2O MINUTES)

NOTE: There are two options for this activity:

1) Use the picture cards provided in the toolkit for Session 4 or, if you choose not to use them, 2) assign each group of girls one of the objects from below.

Separate the girls into groups of three or four.

Explain:

5 Today we will learn how to make a savings plan. First, you will each be assigned a savings goal for this activity.

If you are using the picture cards, distribute a card with a savings goal to each group. If you are not using the cards, simply assign a goal to each group.

Say:

You and your partner(s) need to work together to answer three questions:

1. How much money do you need for this savings goal?

2. How much money do you think you can save each week toward this goal?

3. How many weeks will it then take you to reach this savings goal?

Gather around me so we can do an example together. For example, let's say that a girl like you has a savings goal is to buy a new necklace in the market.

(activity 2 continued on next page)

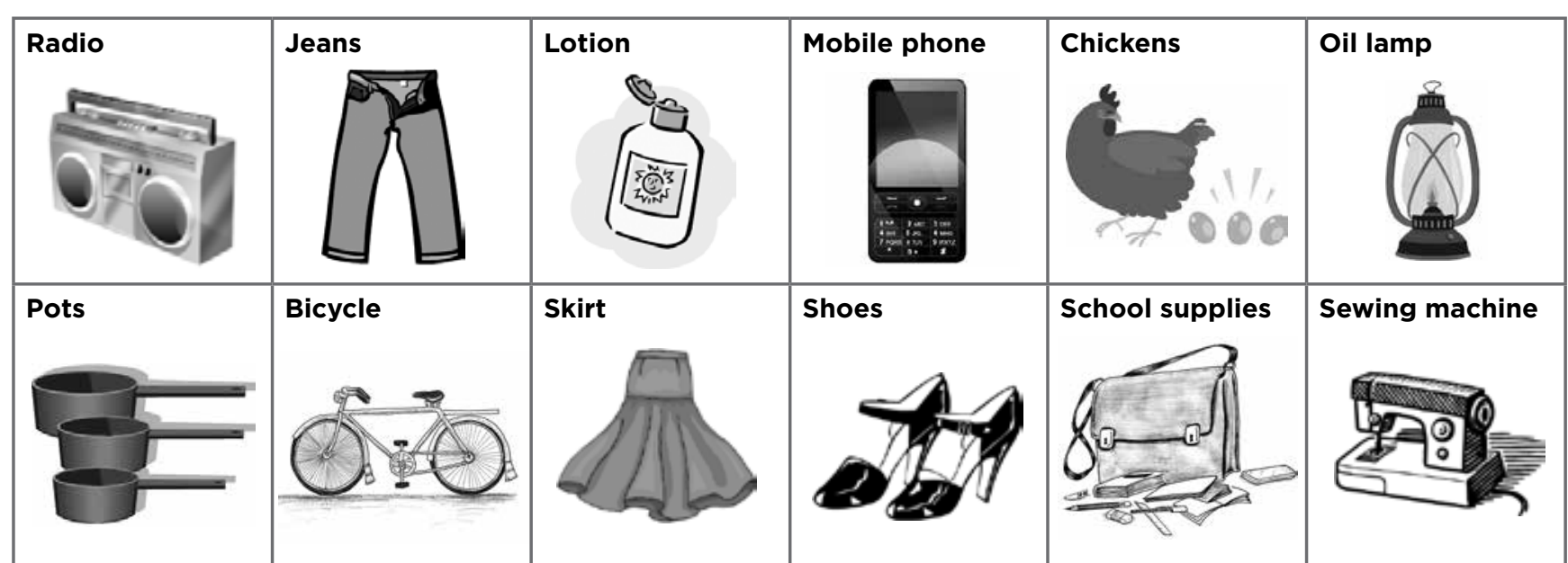




\section{activity 2 (continued)}

\section{Ask:}

\section{S How much might it cost?}

Accept a reasonable answer, write it on the board or flipchart, then

\section{Ask:}

How much money do you think a girl like you might be able to save each week?

Allow some discussion from girls, and come to an agreement on a realistic amount for an average girl to save each week. Write the weekly savings amount that you have agreed upon on the board or flipchart. Then,

\section{Ask:}

5 Now, how many weeks would it take for her to reach her savings goal?

Girls should be able to calculate based on the information on the board. When a girl answers correctly (or help the girls answer if no one can answer correctly) write the following tip on the board, or have it prepared on a flipchart in advance:
TIP:

What I plan to save $\div$ What I can save each week

\section{Number of weeks I need to save in order} to meet my savings goal

EXAMPLE: If the girls say that the necklace will cost KR 25, and they can save KR 5 each week, then the number of weeks to reach their savings goal is $25 \div 5=5$ weeks

NOTE: If you have copies, give a copy of the Savings Plan Worksheet (found on the next page) to each girl now. If you do not have copies, simply copy the worksheet onto the chalk board or a flipchart and display now. Point out that the tip is also found on the worksheet. Alternatively, use the fake Kwacha in the training kit to illustrate how this can be done in practice. For example, have the girls place the amount of money they need to save on the second box and the amount of money they can save each week on the third box. They can use the fake money to figure out how many weeks in total it will take them to reach their goal.

\section{Explain:}

We have just made a savings plan for a girl like us who wants to buy a new necklace. Now, do the same for the savings goal you have been assigned (from the cards or from the ideas generated in Activity one). Together, you will need to:

- Decide how much money you will need for your savings goal in total.

- Agree on how much money you could save each week.

- Using that number, decide for how many weeks you will need to save in order to reach your savings goal.

Allow about five minutes for girls to discuss in their groups or pairs. They can also use the fake Kwacha to make their savings plans. While the girls are talking, circulate to make sure that everyone understands the task. 
activity 3

\section{REVIEW SAVINGS PLANS}

(5 MINUTES)

When girls have had about 5 minutes to create their savings plans, ask a few groups to describe their saving goal and their savings plan to reach that goal. Ask the others for comments. Use the following questions to prompt comments if everyone is silent.

\section{- Is their price realistic?}

-Is the amount they plan to save each week realistic?

-What would happen if they could save more, or less money, each week?

[Save more-they would reach their goal in fewer weeks; Save less-it would take more weeks to reach their goal.]

- What could you do if you needed to reach your savings goal faster?

[Save more each week; change the goal to be less costly.]

\section{- What should they do if they decide to save money} every day, instead of every week?

[Do the same calculations, but then it will give them the number of days it will take to reach their goal instead of weeks.]

When everyone has finished,

Adk:

How do you think a savings plan can help you to save?

Allow girls to discuss the topic, and encourage them to save for their goals in their own lives!

\section{SAVINGS PLAN WORKSHEET}

Sample

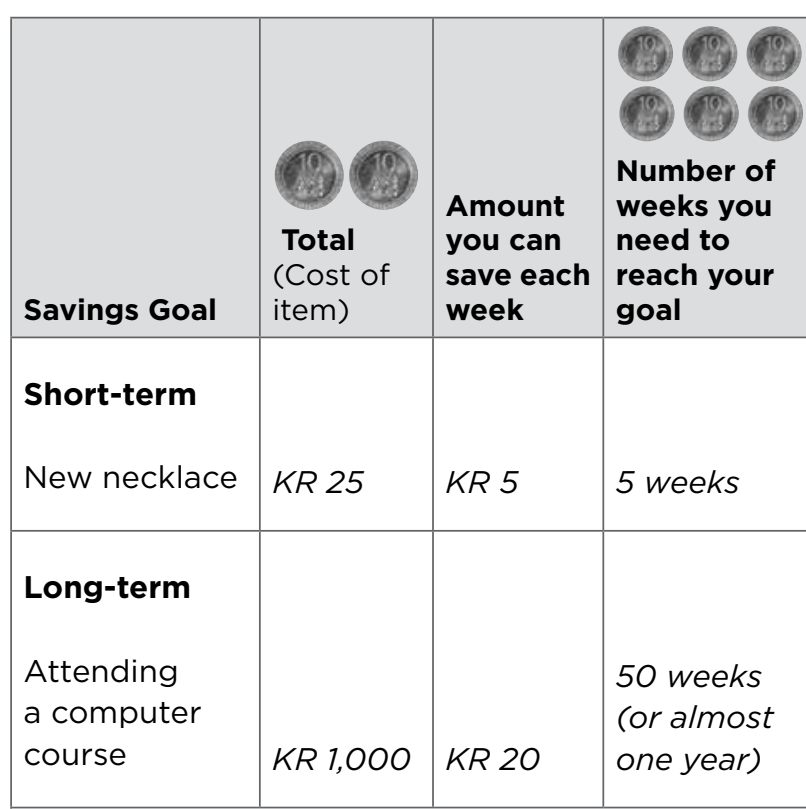

Tip: To find out how many weeks it will take to reach your savings goal, divide the total amount of money you need by the amount you can save each week.

\section{Amount to save :}

Amount you can save each week =

Number of weeks it will take
Do-it-yourself

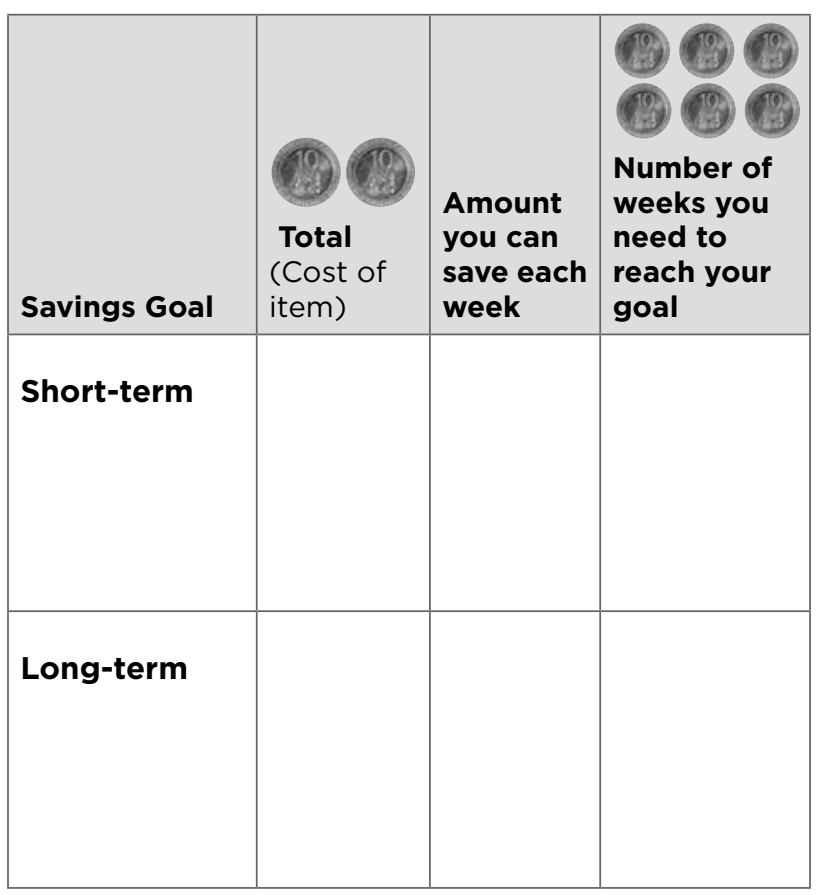




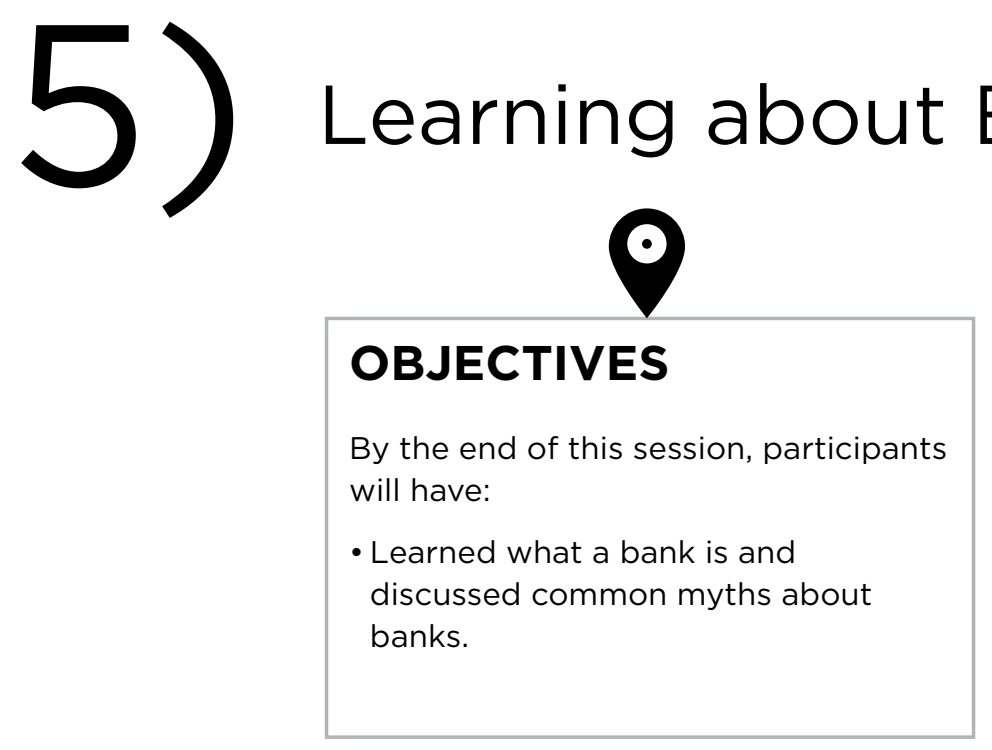

Banks
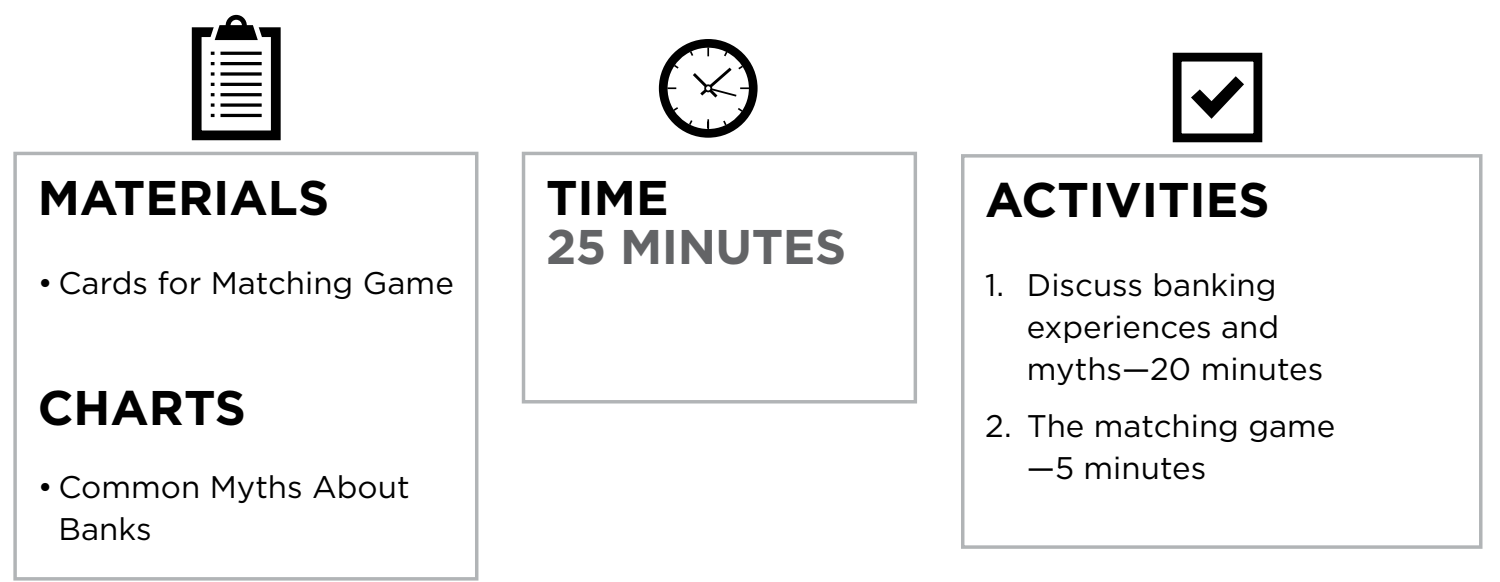
activity 1

\section{DISCUSS BANKING EXPERIENCES AND MYTHS}

(20 MINUTES)

Say:

$\int$ Today we will be talking about banks-what we know and don't know about them. Some of you may have heard about banks or even been inside them.

Ask:

Who can tell what a bank is?

[A place where people keep their money, a place where money is kept in a safe and secure way, a place where people save their money, a place where people put their money to grow it.]

Wrap up the definition of a bank by saying: A bank is a business that offers services to its clients that include a place to keep their money and place to borrow money. The government has the responsibility to check and provide guidelines in the way banks operate.

Say:

Stand up if you know someone who has a bank account

Ask:

Are there one or two volunteers who can share about that person and their bank account?
Say:

Stand up if you have ever been inside a bank

Ask:

(2)

Are there one or two volunteers who can describe their experience in a bank?

Say:

Stand up if you can think of the name of a bank in Zambia.

Call on the girls who are standing and have them call out the banks in Zambia that they know. Make a list on a flipchart of all the banks identified.

Explain:

Sometimes people, places, or institutions develop a reputation-something that many people believe about them, whether it is true or not. For example, perhaps a new girl comes to your school who some people gossip about and tell you not to speak to because she is so strange. But you decide to find out for yourself and it turns out she is quite nice. Banks are similar in that many people believe things about banks that may or may not be true. Today we are going to try to figure out which widely held beliefs about banks are true and which are only myths.
Ask:

When I say the word "bank" what images or thoughts come to your mind?

Remind participants that there are no right or wrong answers. Make a list of all the answers. When the participants are done, go over the list and make the following points if they are missing. Then, as a group, decide which are true and which are myths. Explain

to the girls that a myth is a common belief about something based on opinion

\section{Common Myths About Banks}

- You have to be rich to use a bank.

- Banks are unfriendly.

- Going to the bank takes a lot of time.

- If a bank is robbed, you will lose your money.

- Banks will take your house away.

\section{Ask:}

\section{Are there any questions?}


activity 2

\section{ENERGIZER-THE MATCHING GAME}

(5 MINUTES)

The facilitator chooses a number of well-known banks some of which the girls have mentioned already and writes half of each bank's name on a piece of paper or card. For example, she writes "Nat" on one piece of paper or card and "Save" on another, or "Stan" on one and "Bic" on another to make Natsave and Stanbic. (The number of pieces of paper should match the number of participants in the group. The folded pieces of paper are put in a box or a hat.)

Each girl takes a piece of paper from the hat/box and tries to find the person with matching half of the bank name.

\section{NatSave \\ Stanbic \\ Zanaco \\ Cavmont Bank \\ FINCA Zambia \\ Barclays Bank \\ Finance Bank}

Potential Names of Banks: 


\section{6) Exploring Options for Earning Money}

\begin{tabular}{|l|}
\hline \multicolumn{1}{|c|}{} \\
\hline OBJECTIVES \\
By the end of this session, participants \\
will have: \\
- Identified various options for \\
increasing the money they earn. \\
-Explored roctical approaches \\
to improving existing income- \\
generating activities. \\
- hhought about new ways to earn \\
money. \\
\hline
\end{tabular}

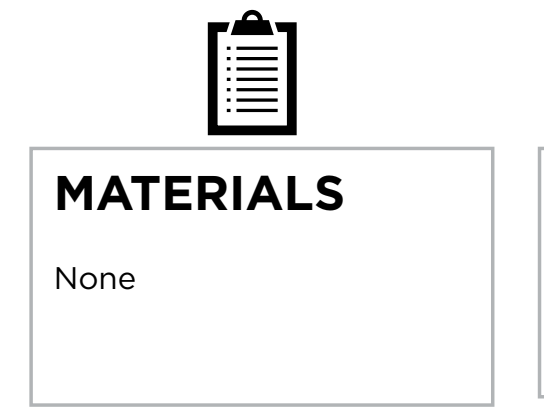

$\otimes$

\section{TIME}

55 MINUTES

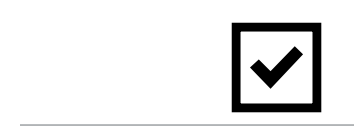

\section{ACTIVITIES}

1. Identify current ways that girls like them earn money-10 minutes

2. Explore ways to improve existing income-generating activities -25 minutes

3. Consider new ways to earn money-20 minutes 


\section{activity 1}

\section{IDENTIFY CURRENT WAYS THAT GIRLS LIKE THEM EARN MONEY}

\section{(10 MINUTES)}

\section{Explain:}

Today we are going to spend some time talking about earning money. To start let's play a small game that will help us to think about some of the current ways that girls like you earn money. In this game, I am going to mention three different ways of earning money.

If you have any experience with the ways of earning money that I mention, I am going to ask you to perform an action, and then give me an example.

- If anyone in our group has ever earned money by doing a small job for someone else-please jump up and hop on one foot.

Now let's ask a few of those hopping to give us an example (and then we can sit back down again)

- If anyone in our group has ever earned money by buying and selling thingsplease jump up and clap your hands.

Now let's as a few of those clapping their hands to give us an example (and then we can sit back down again).

\author{
- If anyone has ever made something \\ or grown something themselves and \\ then sold it to earn money- \\ please jump up and spin around.
}

Now let's ask a few of those spinning around to give us an example (and then we can sit back down).

We can certainly see that girls in our group have lots of experience with different ways to earn money - I wonder how many of you have had experience with all three ways of earning money (doing small jobs, buying and selling things, and making or growing something to sell)

- If anyone here has experience doing all three of these things to earn money-then please jump up, hop on one foot, clap your hands, and spin around (all at the same time)!

You are good examples of how hard girls work to earn money to help their families and reach their own goals-and today we have a lot to learn from you. 
activity 2

\section{EXPLORE WAYS TO IMPROVE EXISTING INCOME-GENERATING ACTIVITIES \\ (25 MINUTES)}

Say:

Now that we know about our existing experience in earning money, let's spend some time exploring ways that we can earn more money doing these same kinds of activities. To help us get started I want to tell you Nambula's story:
Now that we have listened to Nambula's story. Let me ask you a few questions:

\section{- Why was Nambula trying to earn some money?}

[To help buy food for her family.]

\section{NAMBULA'S STORY}

Nambula needed money to help buy food for her family and meet her personal goals, so she started a business roasting maize and selling it to people in the market. At first business was good, but then more and more young people started to copy Nambula (even some of her friends) and business started to drop.

One thing Nambula noticed was that many customers bought a water to drink from another vendor after buying her maize-so she started to sell both roasted maize and water (giving a special price for people who bought both), and that helped grow her business again.

Next, she started to ask her customers what was the secret to the best roasted maize they had ever eaten. One said that in her home vil- lage she had once had roasted maize with fresh chilli sauce on it, and it had been delicious. So Nambula found a recipe for fresh chilli sauce and started to offer a shake of it on her client's maize. This kept some of her customers more loyal to her (and made it easier to sell more water too)!

Finally, Nambula paid close attention whenever she travelled to other markets to see if anyone was trying something new when it came to roasting maize. That is where she first found out about a special grill that used much less charcoal and thus increased profits for the maize vendor, at the same time reducing their cost. Once she saw it, she knew she had to save up to buy one since charcoal was always getting more expensive.

\section{- What business did she start at first? And what challenge did she run into?}

[Selling roasted maize; others copied her business and started selling maize, so her business dropped.]

\section{- What were some things she did to try and} earn more money?

[(i) Adding variety to the product/service she was selling (water, chili on maize); (ii) Asking her customers about improvements she could make; (iii) Keeping her eyes and ears open for new ideas, and improved methods.]

Next, let's see if we could use one of Nambula's strategies to improve one of our own existing ways of earning money. Working in pairs, please talk about one of your current ways of earning money, and decide on an example of how you could use one of Nambula's three strategies to increase your earnings. Remember that her strategies involve: (i) Adding variety to the product/service she was selling; (ii) Asking her customers about improvements she could make; (iii) Keeping her eyes and ears open for new ideas, and improved methods.

After giving the girls 10 minutes to work in pairs ask for one or two volunteers to share their business improvement strategies. 


\section{activity 3}

\section{CONSIDERING NEW WAYS TO EARN MONEY}

\section{(2O MINUTES)}

Say:

Now that we have spoken about ways to improve our existing ways of earning money, let's spend a little bit of time considering new ways to earn money. During today's session (both the game at the start and the activity we just completed) we have been hearing about lots of different ways girls in our group earn money.

So let's take a few minutes now to use each other as a source of good information and advice about new ways to earn money (that we can add to our existing ways of earning money, or use to replace an existing way). Let me invite some of you to:

- Tell me about a new way of earning money you have heard someone speak about in our group today.

- Now why don't you spend 10 minutes talking to that person to get more information and ideas about just how that way of earning money works. Make sure to talk about what kind of skills and qualities someone needs to succeed at that way of earning money.
Let's keep pairing off this way until everyone has someone to speak with (and then let's take 5 minutes or so to speak). After all of the pairs are done, let's rejoin the larger group for one final reflection:

You see-being part of this group is a great source of ideas and support. And who knows maybe some of you will now be able to both improve an existing way of earning money and/or to start a new one !!

NOTE TO TRAINER: After this session would be an ideal time to bring in one or two guests who could serve as role models of ways to earn money-perhaps a woman from the community who has been successful in some type of work or enterprise. Have them speak about their experience, how they got started, challenges they've faced, and their secret to success. Make sure to organize ahead of time with the visitors and inform the girls that someone special will be coming so that there is good attendance. 


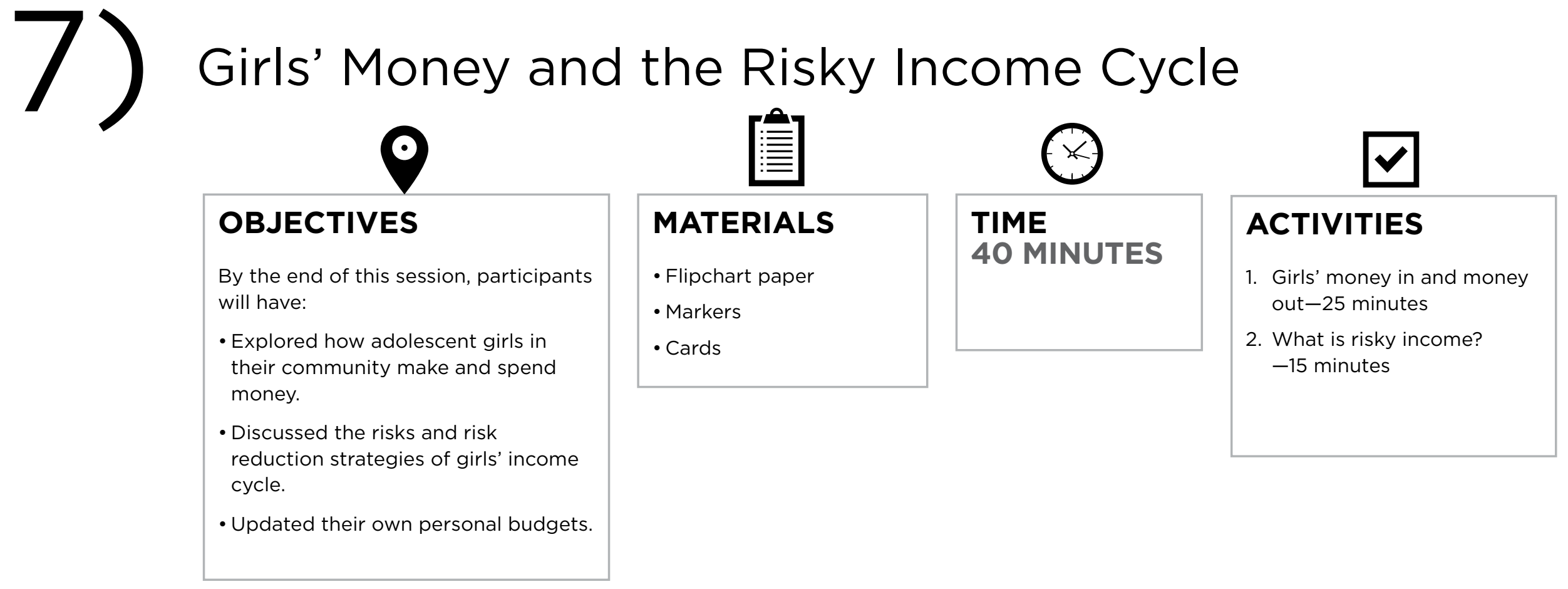




\section{activity 1}

\section{GIRLS MONEY IN AND MONEY OUT}

\section{(25 MINUTES)}

Put a blank piece of flipchart paper on the wall or in the center of the room

\section{Explain:}

Last session we thought about how adults in our community make money. Now we're going to think more about girls like yourselves.

\section{Ask:}

Can I have a volunteer to draw a picture of a typical girl in this community?

As the volunteer finishes her drawing, ask for the girls in the group to pick a name for the girl in the drawing.

Hand out cards or pieces of paper, at least three for each girl.

Say:

On each of these cards, I want you to write one way that [name of girl] gets money. Once you're done, come and paste your cards (or put them down if the flipchart is on the floor) on the left side of [name of girl].
Once everyone is finished, hand out another set of cards (at least three, if possible in a different color) to each girl.

\section{Say:}

On each of these cards, I want you to write one thing that [name of girl] spends money on. Once you're done, come and paste your cards (or put them down if the flipchart is on the floor) on the right side of [name of girl].

Invite the girls to gather around the picture of [name of girl]. Start with the right side. Have the girls help you organize the cards into piles of common expenses (i.e., clothes, food, sanitary towels, school fees, school supplies, rent, etc.)

Say:

Move the expenses around and put the most common expenses on top, followed by somewhat common, and then on the bottom the least common expenses.
Once the girls have agreed on the order of expenses from most common to least common, ask for volunteers to explain a bit more about each expense, including:

\section{- About how much does [name of girl] spend in a} week on this expense?

\section{- In a month?}

- Why does she spend money on this particular item?

Once the conversation about the expenses has concluded, have the girls repeat the process with the sources of money-starting by grouping according to similar sources of cash (i.e., pocket money from parents, boyfriends, casual chores, etc.), and then have them rank the sources of income by most common to least common.

When the girls have agreed on an order,

Ark:

About how much does a girl get from this source of money in a month?

How often does she get this income-Daily? Weekly? Monthly?

Can someone describe more about each of these sources of money? 


\section{activity 2}

\section{WHAT IS RISKY INCOME?}

(15 MINUTES)

NOTE TO TRAINER: It is common for adolescent girls to get money from sources that may put them at risk of unsafe sexual behavior. This can be from different kinds of boyfriends or other older men who give them money and gifts in exchange for sex. When girls depend on these men for money and other resources, it can make it harder for them to be in a position to say no to sex or to negotiate for safer sex, i.e., condom use. It is often the case that girls who have their own money, or have a little bit of economic independence, are less dependent on men for money.

\section{Ask:}

In our previous discussions, we talked about different places that a girl like [name of girl] would possibly get her money from. Do you think it matters where this money comes from?

From the different ways that [name of girl] gets money, which are some that might have some risks to them?

For each of the risky sources of income mentioned,

\section{Ask:}

What makes this way of getting money risky?

What can [name of girl] do to avoid some of these risks?
If "from men" or "from boyfriends" does not come up,

Ask:

What are the risks in girls getting money or other gifts from boyfriends or other men that they know?

If [name of girl] had her own money that she kept aside as savings-either at her home or in a bank account, how would that change the way she gets money from boyfriends or other men?

Encourage discussion and then explain:

Often, when other people apart from your parents give you money, there is an expectation that they will get something back. In many cases, what you give back is work. You wash clothes, plait hair, work in the field, and in exchange you get paid an amount of money. However, when you are getting money that is not in exchange for work, especially if it comes from boyfriends or other men that you know, there may be an expectation that eventually you will give something back. Maybe that expectation is some kind of sexual activity. When you are in this situation, or feeling like you "owe" someone something for the money or gift that they gave you, it may be hard to say no to sex or to ask your partner to use a condom.
Let's be aware of these kind of expectations before we accept money or gifts from boyfriends or other men. Some of the risks associated with getting money through such ways include the possibility of contracting HIV \& AIDS and other sexually transmitted infections, unwanted pregnancies, involvement in drugs, in sexual violence and sexual exploitation, forced marriages, and exposure to other social and health risks.

Therefore, we can try to think about our savings as a way that we can use our own money so that we do not have to depend on these gifts or money from men for our daily needs.

Ask:

Does anyone here have an example of when something like this happened to someone they know?

Let a few girls share examples. This may open up a larger conversation. You will have to decide if you want to keep going with the session or let the girls talk more about this topic. 
Know the Difference Between Needs and Wants

OBJECTIVES
By the end of this session, participants
will have:
- Distinguished between needs and
wants.
- Described Bwalya and Mutinta's
needs and wants.
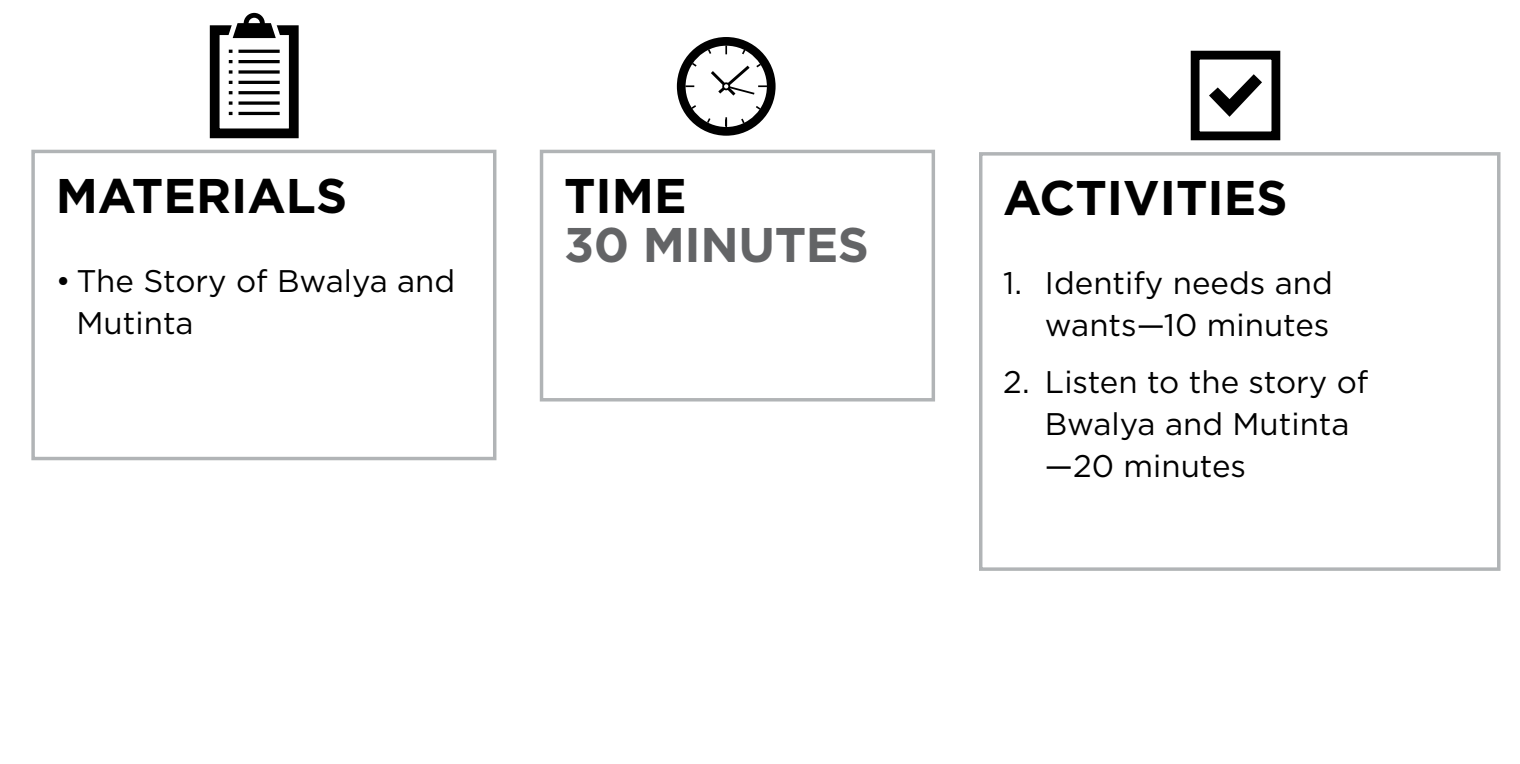


\section{activity 1}

\section{IDENTIFY NEEDS AND WANTS}

\section{(10 MINUTES)}

\section{Begin the session with a short game:}

We are going to write the letters of two words with our bodies. Ready? Follow me!

Show the girls how to write the word "needs" with their head. Tell them to move their head in the air to "write" the letters the way they would move a pen on a piece of paper. After, show the girls how to write the word "wants" with their knees. Have fun making the letters and acting silly!

\section{Explain:}

$\bigcirc$ We spend money on many things. Some of these things are necessary for our survival. These things are called NEEDS. Others are things that we want, and when we buy them, we are happy. We call these things WANTS. Today, we are going to discuss the difference between the things that we want and the things that we need. One part of controlling what we spend is knowing the difference between needs and wants.

I want you to imagine a line now between this side of the room and that side of the room.

One end of the line represents our NEEDS. The other end represents our WANTS.

Choose two places in your room or area to represent "wants" and "needs" so that girls can form a line between the two places. If you are outside, pick two objects. Alternatively, you could ask two girls to represent needs and wants and stand in two different spots.
I'm going to say an expense, something that we could spend money on. Your job is to decide if this expense is a WANT or NEED.

I am not going to wait for everyone to agree. If you think that the expense is only a need, place yourself close to the object [or person] that represents NEEDS. If you think that the expense is only a want and can never be considered as a need, place yourself close to the object [or person] that represents WANTS. But if you are not sure, or you think that in some cases, the expense could be either a want or a need, place yourself somewhere in the middle of the two objects [or people].

For example, if I say "bangles," and you think that it is more of a want than a need, you can stand here.

Demonstrate by standing closer to the object or person that represents "WANTS."

However, if I say "medicine," and you think that medicine is definitely a need, stand here.

Demonstrate by standing closer to the object of the person that represents "NEEDS."

When you are sure everyone understands the game, read the following expenses, one at a time. After each expense, give the girls time to place themselves along the line of wants/needs.
1. Water
8. Sweets
2. A second pair of shoes
9. Hair products
3. Talk time
4. Bus fare
5. Food
6. Rent
10. Savings to help you in case of emergencies
11. Seeds for the next planting season
7. Money to start a business 12. Fertilizer

After the girls have chosen their place along the line ask one or two of them in different spots to explain why they chose to stand where they did.

NOTE TO TRAINER: For the game above, make sure to keep the group moving. If you stop to discuss each statement, the time needed for the activity will increase greatly. Keep the group moving to keep the energy of the game!

When you have finished all 12 items above,

Ask:

\section{Are needs and wants the same for everyone?}

After 2-3 girls have had a chance to answer, Say:

Needs and wants are often different for different people. But to manage our money well, we have to decide what needs and wants are for us. The key to saving is making good decisions about spending our money. If you can spend less money and save even just a little bit, you will attain your savings goals in the end. Your shortterm loss can become your long-term gain. 
activity 2

\title{
LISTEN TO THE STORY OF BWALYA AND MUTINTA
}

\author{
(2O MINUTES)
}

The objective of the story of Bwalya and Mutinta is to help girls understand the difference between needs and wants with an example. If you have time and resources, make handouts of the story for girls to follow along with and take home to read later.

Read the story of Bwalya and Mutinta.

Ask girls the following questions to make sure that everyone understands the story:

How does Bwalya manage her money?

[She spends it all, mostly on things that she wants like Fanta, new clothes, and transport.]

\section{How does Mutinta manage her money?}

[She saves some of her money, and she has cut down on her spending, too. She spends mostly on needs-she gives some to her mother for household expenses, and spends a small amount on herself.]

\section{Are you more like Bwalya or Mutinta? Why?}

Say:

Next time, we will keep talking about the Eight Steps for Savings. Until then, pay close attention to what you spend money on!

\section{THE STORY OF BWALYA AND MUTINTA}

Bwalya and Mutinta work together at a hair salon. The two girls each make about KR 400 each month.

Bwalya spends all of her money each month. Everybody thinks that Bwalya makes more money than Mutinta because Bwalya wears more new clothes and shoes. She often takes buses while Mutinta walks. Bwalya often buys Fanta and Coke at a local shop while Mutinta drinks water or tea at home. Sometimes she helps her friends when they need money, or buys them a soda as well. Bwalya also buys makeup whenever she has some money in her pocket. She never saves money.

Mutinta saves KR 50 each month. It has not been easy, but she has cut down a lot on spending money. Instead of buying new jewelry, she decided to continue wearing some of her old jewelry. She also has decided to wait a few months before buying a new pair of shoes. Even though she still buys snacks from time to time and gives some money to her mother for household needs, she has found that it is possible for her to save a little money by thinking about the difference between her needs and wants.

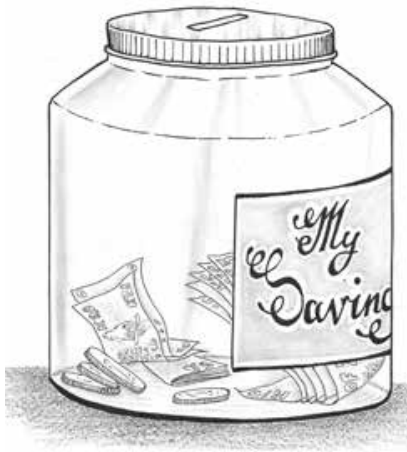


9) Control Spending

\begin{tabular}{|c|c|c|c|}
\hline $\begin{array}{l}\text { OBJECTIVES } \\
\text { By the end of this session, participants } \\
\text { will have: } \\
\text { - Understood the idea of making } \\
\text { spending priorities. } \\
\text { - Practiced making a personal budget. }\end{array}$ & $\begin{array}{l}\text { MATERIALS } \\
\text { - Spending Game } \\
\text { - Budget }\end{array}$ & $\begin{array}{l}\text { TIME } \\
40 \text { MINUTES }\end{array}$ & $\begin{array}{l}\text { ACTIVITIES } \\
\text { 1. Make spending } \\
\text { decisions-20 minutes } \\
\text { 2. Introduce the budget } \\
-20 \text { minutes }\end{array}$ \\
\hline
\end{tabular}




\section{activity 1}

\section{MAKE SPENDING DECISIONS}

\section{(10 MINUTES)}

Ask the girls to sit in a circle or gather around so that everyone can see. Give each girl 10 stones (or sticks or pieces of paper) and tell them that each one represents 10 Kwacha-so take care of them!

\section{Explain:}

$\int$ We are going to play a game called the Spending Game. In this game you are going to have a series of opportunities to spend the 100 Kwacha I have just given you (which you can imagine that you earned doing some small jobs for me). Each of you will make your own choices-and there is no right or wrong way to spend your money.

-What questions do you have?

\section{Next say:}

I want all of you to imagine that it is Saturday and you have decided to go to the market to buy a new outfit. You each have 100 Kwacha that you earned from baby sitting for a neighborand you will now have a series of opportunities to spend it.

${ }^{* *}$ As the girls spend money, make a note of what each one buys from you.**
1. It is hot and your feet are tired. A taxi driver asks if you want a ride to and from the market today-it just costs 10 Kwacha. Pay me 10 Kwacha if you accept his offer and then take a quick drive to the market (or just keep walking on your tired feet).

2. You arrive at the market (in the taxi or by foot) and you see that some of your friends are already there. Your best friend asks if you have enough money to buy you and her something to eat. Pay Me 10 Kwacha if you decide to buy you and your friend some lunch (or just tell her that you are not hungry and keep moving).

3. While you are heading toward your favorite shop a street vendor catches your eye. He has some very attractive dresses for sale-and matching sandals. The price is only 80 Kwacha but he says you have to decide right away as he only has a few outfits available. Pay me 80 Kwacha to buy the dress and sandals from him or move on (and only let the first three girls buy from him as his supply is limited).

4. Next you go to your favorite shop where the owner knows you and gives you good prices. She has some very nice dresses for 50 Kwacha-and a good supply. Pay me 50 Kwacha to buy a dress.

5. Now you are looking for shoes-but it is hard to find ones that match your new dress. You go to one store and the perfect shoes cost $40 \mathrm{Kwacha}$. Pay me 40 Kwacha to buy shoes-or move on.
6. You remember that you have run out of soap and lotion at home and you see a very good price to buy one of each for just 10 Kwacha. Pay me 10 Kwacha or miss out on this good price.

7. You are feeling unlucky when it comes to buying a new outfit when suddenly you see that there is a new trader in town who has very special pricesyou can buy a dress, shoes, and a necklace for 70 Kwacha. Pay me 70 Kwacha to buy them.

8. You are getting ready to go home when you see that your Auntie is in the market. She asks if she can borrow 10 Kwacha from you to buy some med icine as she is not feeling well. Pay me 10 Kwacha if you lend the money to her.

9. On your way to leave the market you see a woman beside a broken down truck selling dresses for 30 Kwacha and shoes for only 20 Kwacha (a special price because she needs to raise money to fix her truck immediately). Pay me 30 Kwacha to buy a dress and $20 \mathrm{Kwacha}$ to buy shoes at this very special price

10. Now it is time to go home. If you paid for a ride with the taxi driver then go home with him. If not, then enjoy the walk home...

Thank the girls for playing the game. 


\title{
activity 2
}

\section{INTRODUCE THE BUDGET}

\author{
(20 MINUTES)
}

Ask girls to reflect on what they spent their money on during the first round of the Spending Game before.

\section{-What did you end up spending your money on?} And did you save any?

\section{- How did you make your decisions?}

-Are you happy with how you spent your money?

Say:

Now that you have thought about your spending decisions, it is time to learn about something called a "budget." A budget is a tool to help you plan for the money that you earn and the money that you spend. We can use it to plan both our "money coming in" and our "money going out" over a period of time. It can help us to spend our money wisely, and to save more money that we might without it.

A budget is simply our planned "money coming in" and how we will spend that money over a period of time-like a week or a month.

If flipchart paper is available, prepare a budget as a sample and post it so everyone can see, or make a photocopy of the budget for each girl. If there is no flipchart paper, show girls the budget on this page. Explain the different sections of the budget.

\section{Say:}

Now let's work with another group member to plan for Round Two of the Spending Game. We will all start out with the same amount of money (100 Kwacha) which we can put in our "money in" row and we will have the same choices to make. But this time we have a chance to plan ahead and make a budget.

So take a few minutes to "budget" how you will use your 100 Kwacha. Then we will quickly go through the same steps for the game.

Repeat all the same steps (buying choices) as in Round one.

Now de-brief the game.

Ask:

-What did you end up spending your money on? And did you save any?

- How did you make your decisions this time? Were they different or the same?

\section{- Are you more happy with how you spent your} money this time? Why?

\begin{tabular}{|l|l|}
\hline MONEY IN & \\
\hline & KR 100 \\
\hline MONEY OUT & \\
\hline Transport & \\
\hline Food & \\
\hline Clothing & \\
\hline Soap/lotion & \\
\hline & \\
\hline
\end{tabular}




\section{activity 2 (continued)}

Now introduce a more general budget template. If flipchart paper is available, prepare a budget like the one on the right as a sample and post it so everyone can see, or make a photocopy of the budget for each girl. If there is no flipchart paper, show girls the budget on the following page. Explain the different sections of the budget.

This next budget is an example of one we could all use to track our actual money in and money out over a typical week. It uses the same overall design as the one we just used in our game, but it is closer to what we might use in real life to apply our new budget making skills.

Tell the girls to try to make a budget for the coming week.

Say:

S Think about what "money in" you will have next week. That is money that you get from different sources. Then think about what you will spend next week.

Give the girls 10 minutes to work on a personal budget.

\section{Then say:}

$S$ Good job. A budget is something that you can use to plan, and can be updating as your money in and money out change; that is, if you get money from new or different sources, or spend it on different things, or in different amounts. Practice at home as making a budget and sticking to it take practice!

Remember, if you don't have enough money in, you may have to reduce what you spend. If you have more money coming in than what you will spend, you can always save!

Don't worry if this seems hard. Just start by writing down what you spend. That is the first step to having a good budget.

Before we leave, I want to give you two rules for savings.

Repeat after me:

- Spend less than you earn!

- Save a little every week!

If you follow these simple rules, your savings are sure to grow.

Thank the girls for their work.

\section{BUDGET TEMPLATE}

\begin{tabular}{|c|c|c|c|}
\hline & & $\begin{array}{l}\text { What I earned/ } \\
\text { spent last week }\end{array}$ & $\begin{array}{l}\text { What I plan to earn/ } \\
\text { spend next week }\end{array}$ \\
\hline & MONEY IN (income) & & \\
\hline 1 & & & \\
\hline 2 & $\begin{array}{l}\text { Gifts or } \\
\text { alowances }\end{array}$ & & \\
\hline & TOTAL & & \\
\hline & MONEY OUT (expenses) & & \\
\hline 1 & Food & & \\
\hline 2 & Clothe & & \\
\hline 3 & Phone & & \\
\hline 4 & Transport & & \\
\hline 5 & $\begin{array}{l}\text { School } \\
\text { supplies }\end{array}$ & & \\
\hline 6 & $\begin{array}{l}\text { Personal items } \\
\text { (i.e., sanitary pads or } \\
\text { beauty products) }\end{array}$ & & \\
\hline 7 & Medicine & & \\
\hline 8 & Savings & & \\
\hline 9 & Emergencies & & \\
\hline 10 & Other & & \\
\hline & TOTAL & & \\
\hline
\end{tabular}


10) Think About the Future: Money In and Money Out

OBJECTIVES
By the end of this session, participants
will have:
- Reported the ways in which a girl
(Mwaka) plans ahead for her income
and expenses.
- Described the behavior of someone
who does not plan ahead.
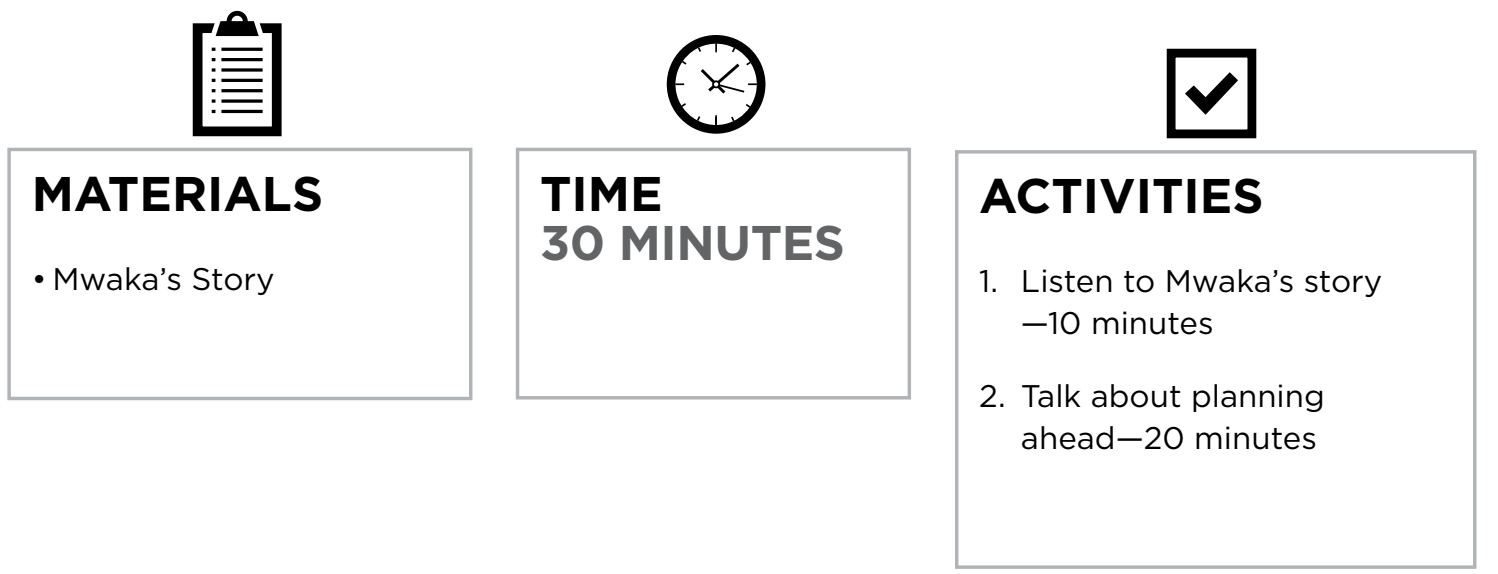


\section{activity 1}

\section{LISTEN TO MWAKA'S STORY}

\section{(10 MINUTES)}

Explain that the "Savings Step of the Day" is: "Think About the Future: Money In and Money Out!" Tell girls that another way to say "money coming in" is "income," and another way to say "money going out" is expenses.

Tell the story on the following page about Mwaka. [Note that there are two versions to this story presented: Urban and Rural. Choose which option is more appropriate for the setting where you are facilitatingi.e., option one is more similar to an urban scenario and option two for a rural scenario.]

When you have told the story,

Ack:

\section{How does Mwaka earn money?}

[Helping her aunt, working as a server.]

\section{How does she manage the money she earns} (her money coming in or "income")?

[Thinks about her expenses for the week first, saves with her group, saves a little at home for her batteries when possible.]

\section{Why doesn't Mwaka listen to her radio more often?}

[She does not have enough money for batteries.]

\section{How does planning ahead help Mwaka?}

[She can meet her needs, and save for some of her wants.] 


\section{MWAKA'S STORY [URBAN]}

Mwaka is 17 and loves listening to radio programs. She listens to the radio whenever she gets the chance! She likes all programs-like the news, or educational programs-but her favorites are latest music hits. She is lucky because her aunt gave her a radio as a gift. Yet, she rarely has the money to buy batteries to keep the radio going.

Mwaka usually works one or two days a week as a waitress at her neighbor's restaurant or helping her aunt at her stall in the market and earns about KR 50 a day. Each week, Mwaka thinks about what she needs to spend money on, like food, transportation, or lotion. She sets aside the money she will need for those items and saves the little that is left with her savings group. She is saving that money to buy a sewing machine.

But sometimes she will keep a little extra at home, just in case she fails to get work in the coming week, or some other need for money comes up-as it usually does! However, every once in a while, Mwaka finds herself with a small amount of extra pocket money, and only then does she go to the shop to buy new batteries for her radio.

\section{MWAKA'S STORY [RURAL]}

Mwaka is 17 and loves listening to radio programs. She listens to the radio whenever she gets the chance! She likes all programslike lima time, or educational programs-but her favorites are radio sketches in her own language. She is lucky because her grandfather has a radio she borrows sometimes to listen to her programs. Mwaka has an agreement with her grandfather that every time she wants to listen to the radio, she has to buy batteries because her grandfather can't afford any extra batteries. Moreover, Mwaka rarely has the money to buy batteries to keep the radio going each time she needs to listen to it.

Mwaka usually works one or two days a week weeding her neighbor's field or helping her aunt at her stand in the village market and earns about KR 20 a day. Each week, Mwaka thinks about what she needs to spend money on, like food, paraffin for the lamp, charcoal, or vaseline. She sets aside the money she will need for those items and saves the little that is left with her savings group. She is saving that money to buy a sewing machine.

But sometimes she will keep a little extra at home, just in case she fails to get work in the coming week, or some other need for money comes up-as it usually does! However, every once in a while, Mwaka finds herself with a small amount of extra pocket money, and only then does she go to the shop to buy new batteries to listen to her grandfather's radio. 
activity 2

\section{TALK ABOUT PLANNING AHEAD}

(2O MINUTES)

Divide girls into groups of three or four

\section{Explain:}

You have heard the story of Mwaka. She thinks ahead about what she needs to buy and sets aside her money for those needs. Your job is to work together and create a very short story about a girl (or girls) who are NOT like Mwaka. That is, the girls in your story should do the opposite of Mwaka. The girls in your story will NOT know how much they earn and NOT plan ahead for the things they need to buy.

While you can think about things you know in real life, please don't use anyone's real name or situation in your story. Come up with a fake name to protect the person who didn't plan! You have five minutes to come up with a story together.

Circulate while the girls are planning to make sure that everyone understands the task and to keep them on track. After five minutes, ask a volunteer from each group to tell her story. Clap for each group!
If time allows,

Ask:

Have you seen any girls in your community who are more like-Mwaka or the girls in these stories?

\section{What are some specific things that make} them more like Mwaka or the girls in these stories?

What can they do to be more like Mwaka and plan ahead?

[Use their budget, think about my expenses before they make them, spend less than they earn, save money with their group, save money at home.]

NOTE TO TRAINER: If your group of girls enjoys dramas and role plays, you could replace Step 2 above with a more "dramatic" activity. Put girls in groups of three or fours and ask them to create a short skit that shows a girl or girls who do the opposite of Mwaka-that is, they do NOT plan ahead. Girls can prepare the skits together at home, and present them the next time you come together. 
11) Save Regularly!

OBJECTIVES
By the end of this session, participants
will have:
- Determined whether statements
about saving are true or false.
- Evaluated the savings behavior of
two cousins.
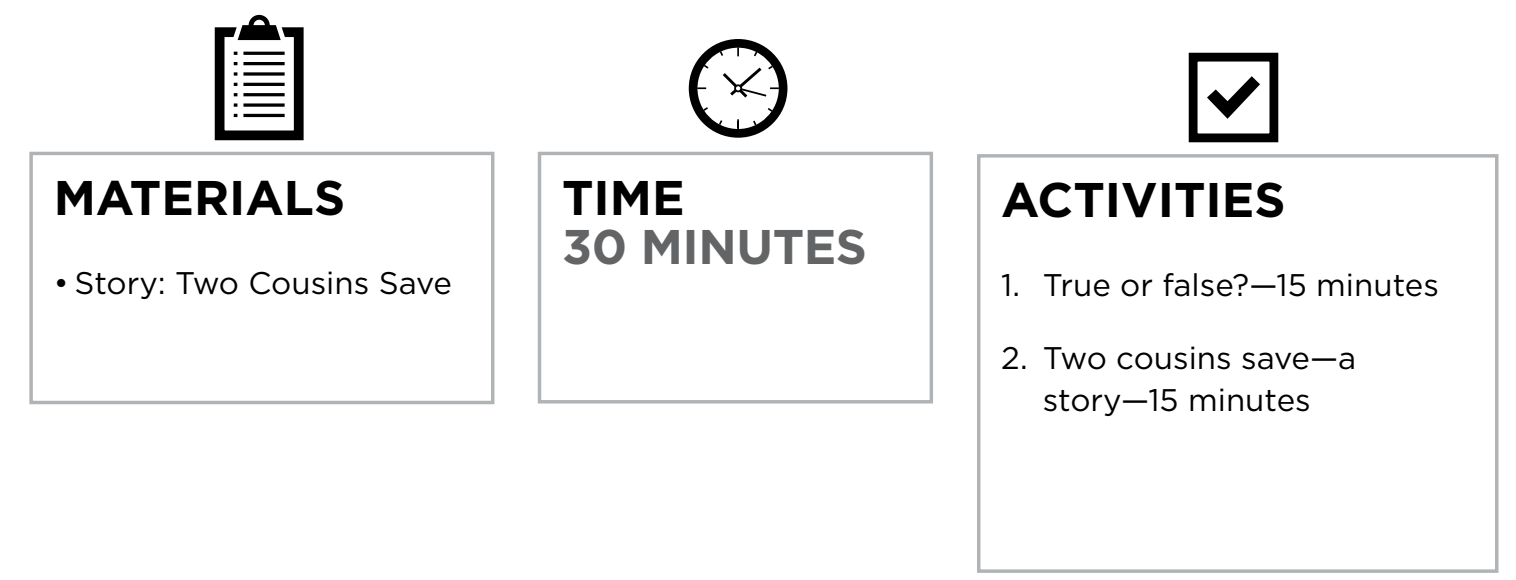


\section{activity 1}

\section{TRUE OR FALSE?}

(15 MINUTES)

Introduce the Savings Step of the Day: "Save Regularly!”

Pick two girls or ask for two volunteers to stand in two places at the front of the room. Tell everyone that one girl represents "True" while the other represents "False."

\section{Explain:}

We are going to play a game where you will have to stand up and go behind one of these girls. This time, I will give you a series of statements about saving.

For each statement, you must decide if you think it is true or false. If you think the statement is true (point to the girl representing "True") stand behind your friend here. If you think it is false (point to the girl representing "False") stand behind your friend here. If you are not sure, make your best guess.

Let's do an example to make sure everyone understands. I will give you a statement. Think about the statement for just a moment, and then move to the place along the line that shows your answer.

"Saving money can help you in the future"
When everyone has chosen a place, ask two girlsone from the "true" side, one from the "false" sideto explain why they chose that spot. Explain that the statement is "false", because it depends on the individual's needs. Then, continue with the activity.

\section{Ask:}

\section{What questions do you have?}

Choose 4-5 of the statements in the box on the right to read. (NOTE: During the activity, if you find that the discussions are taking a lot of time, cut down on the number of statements.)

After each statement, instruct the girls to move to a place along the line that shows how they think about the statement. Ask a few girls in different places along the line to explain their choice. Then read the next statement.

\section{Explain:}

Saving is hard to do when there is not enough money to pay for all the things we need. However, saving can be easier when you decide to save regularly. Even if you can only save a little bit on a regular basis, making saving a habit will slowly build up a sum of money and help you reach your goals.

\section{Agree/Disagree Statements}

- You have to have a large sum of money to save. [False-you can save even small amounts of money.]

- Saving every week requires discipline. [True.]

- Saving tiny amounts of money is a waste of time. [False-even small amounts add up with time.]

- You should only save the money you have left over at the end of the week or month.

[False-it is best to save before you spend.]

- Saving a little bit of money each week will eventually result in a larger amount of money you can use for something important to you. [True.]

- Girls like me do not have enough money to save. [False-most girls have at least a small amount they can put aside to save.]

- Girls should not have to save money; their parents should save for them.

[False-everyone has emergencies and future needs, so girls should save too.] 


\section{activity 2}

\section{TWO COUSINS SAVE-A STORY}

\section{(15 MINUTES)}

Read the story on the right ("Two Cousins Save"). Discuss the story, using the following questions to make sure the girls understood the story:

\section{- What happened to the girls' savings plan?}

[They weren't able to follow it when Beatrice found other things to spend the money on.]

\section{- Why is Beatrice having a hard time saving every week?}

[She wants to go to variety shows, she had to help her sick mother one week.]

\section{- What do you think about Beatrice's plan to collect a larger amount of money later?}

[It might not work because she might find it difficult to save a larger amount of money that she did not plan for, and then the girls' plans will fail. She might also think about changing the spending decisions she has easy control over like going to a variety show.]

- What are the girls' chances starting their business making fritters? [They are probably not good based on what has happened with Beatrice.]

Conclude by asking:

How would things work out differently for Beatrice and Eva if they were members of a savings group or had a savings account?

[The group encourages discipline to save regularly, and an account makes it more difficult to access and to spend your money on unplanned purchases. They are more certain paths to achieving your goals.]

\section{TWO COUSINS SAVE}

Beatrice and Eva are cousins who live next door to each other. They decide that they can make some money selling fritters. Since they need the initial utensils and ingredients to start, the two girls make a promise to start saving so they can buy the necessary items. They know exactly what they want to buy and its price. They decide to save weekly and together agree on KR 100 that they think they can afford to save.

Eva is good at math; the cousins promise to each save KR 5 every week. So, they will save KR 10 in total each week. This means that they will have to save for 10 weeks before they can start the business. It seems like a long time, but by putting their savings together, it will go faster.

For the first few weeks, both cousins make sacrifices in order to save, and their family congratulates them! But Beatrice becomes tempted by her love for entertainment and goes to watch a variety show at her school. She even pays for a friend to go with her. Then her mother is sick and cannot work for a week, so Beatrice has to use some of her money to buy food for the house.

The next week, when Eva asks Beatrice for her savings, Beatrice just shrugs and says she can't afford to save right now. She promises to give Eva a bigger sum of money later, after she works at their neighbor's shop. "Don't worry," she says, "l'll work hard and save a lot next month. It will all work out the same." 


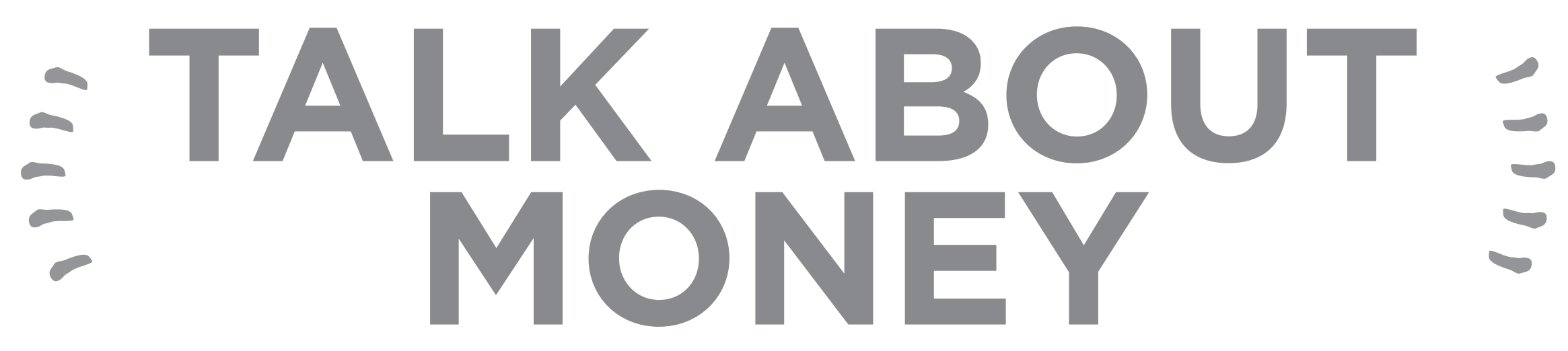


12) Save in a safe Place

\begin{tabular}{l} 
OBJECTIVES \\
By the end of this session, participants \\
will have: \\
- Listed the advantages and \\
disadvantages of saving at a bank. \\
- Listed the advantages and \\
disadvantages of saving at home. \\
- Compared saving at a bank and \\
saving at home. \\
\hline
\end{tabular}
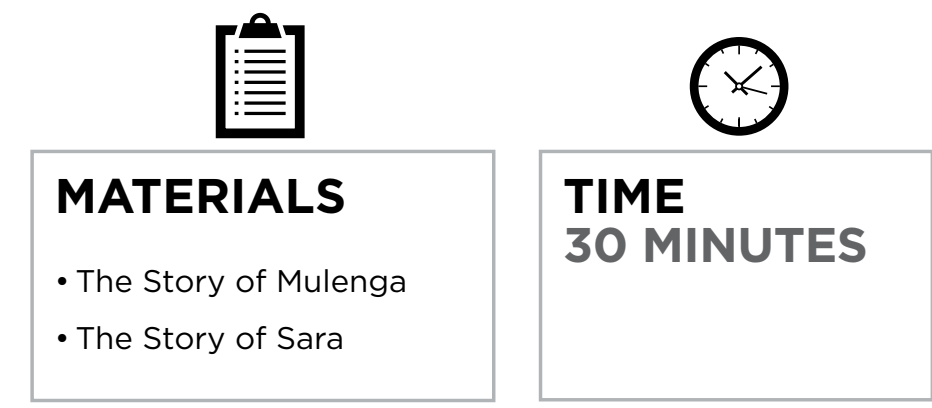

ACTIVITIES
1. The advantages and
disadvantages of saving in
a bank-15 minutes
2. The advantages and
disadvantages of saving at
home-15 minutes


activity 1

\section{THE ADVANTAGES AND DISADVANTAGES OF SAVING IN A BANK}

(15 MINUTES)

Say:

Saving can be difficult because there are so many demands on our money. When we are able to save, it is important to put our savings someplace safe, where they cannot be taken by someone else, and where we ourselves will be less tempted to spend them. Our "Savings Step of the Day" is: Save in a Safe Place!

Ask:

$\bigcirc$ What makes a place safe for keeping money?

[A place where no one else knows about it, where only you have access to the money, where only you can decide what to do with the money and when, where the money will not be stolen.]

Now we are going to listen to and discuss two stories about girls who saved in two different places.

Explain:

Mulenga and Sara are cousins who live in [put name of local community]. Mulenga is 17 years old, and Sara is 18. For Christmas, their grandmother gave each of them KR 200. Both cousins planned to save this money to reach important goals, but they chose different paths.
We'll listen to their stories, and talk about what happened in each one.

Tell the story of Mulenga (box on the right).

Ask:

What are Mulenga's savings goals?

[To buy tools to start her own mobile phone repair business when she finishes technical school.]

\section{How does Mulenga get the money to} save and achieve her goals?

[She saves her grandmother's gift, and saves money from her lunches and transportation when possible.]

\section{How will having a savings account} help Mulenga reach her goals?

[Keeping money in an account reduces spending on 'wants,' such as the shoes Mulenga does not buy. It also keeps the money safe and secure.]

\section{What are the challenges of putting} your savings into an account?

[You have to go to the bank to deposit and withdraw money, so if you need the money immediately, you cannot get it; access to your savings is restricted.]

\section{THE STORY OF MULENGA}

Mulenga is a girl with a dream: To finish classes at her technical school, buy the necessary tools, and start a mobile phone repair business. She wants to save her grandmother's gift and add to it until she has enough money to buy the tools.

Mulenga opens a savings account to help her save. She puts the entire KR 200 into her account. So, while it was easy to open the account, Mulenga wants to continue depositing some money and keep saving until she has enough for the repair tools-which costs KR 400. On some days she walks to school to save on transportation and on other days she skips lunch to save. She is either really tired or really hungry by the time she reaches home from school!

When Mulenga's brother gets married, she really wants a new dress for the wedding. She knows she is saving up for the tools for her business, but she goes to the bank to withdraw KR 50 for a dress. On her way back from the bank, Mulenga sees a pair of shoes in the market that would match her dress. But she does not have enough cash in her pocket, or time to return to the bank and withdraw more money. Mulenga realizes that although she is tempted to buy the shoes, she does not really need them, and continues on her way home. Another day, Mulenga's mother asks for KR 5 to buy some vegetables for dinner, but Mulenga does not have any cash with her and the bank is too far away to go and withdraw the money. 


\section{activity 2}

\section{THE ADVANTAGES AND DISADVANTAGES OF SAVING AT HOME}

(15 MINUTES)

Say:

Now let's hear about what happened to Mulenga's cousin, Sara.

Read the story of Sara below.

\section{Ask:}

How does keeping money at home make it harder for Sara to save?

[Keeping money at home makes it too easy to spend. Others who need money will pressure you to give it to them; it can be stolen or borrowed.]

\section{What are the advantages of saving at home} for Sara?

[She has easy access to money that she can spend on things she wants or use to help her family.]

Which place do you choose for saving your money? Why?
Allow the girls to discuss their choice for savings realistically. There may be reasons they choose to save in different places. The objective of the lesson is to help them compare the options and think about the best and safest place for their own savings.

\section{THE STORY OF SARA}

Sara wants to save to enroll in a computer course, but she does not want to open a savings account because she thinks it will limit her flexibility with her savings. She decides to hide her KR 200 in a home bank buried under a pile of clothes in her cupboard.

Sara is easily tempted by videos or other CDs she sees in the market. So, about once a month, she takes a little money out of her home bank to buy something. That makes her so happy! And sometimes, when she has had a lot of business, she puts money into her home bank.

One day, her uncle sees her put away her home bank, and the next time she takes it out, she discovers that some money is missing. Another time, her sister begs her for money for transportation to get to the place where she has work that day. When the time comes to pay the first installment for the computer course, Sara realizes that she does not have enough money in her home bank. 
13) Dealing with Setbacks in Saving

\begin{tabular}{|l|l|l|}
\hline OBJECTIVES & MATERIALS \\
$\begin{array}{l}\text { By the end of this session, participants } \\
\text { will have: }\end{array}$ \\
$\begin{array}{l}\text { - Explored the challenges and possible } \\
\text { setbacks expected in saving. } \\
\text { - Understood difficulties encountered } \\
\text { when plans don't go as planned. } \\
\text { - Understood how to plan and deal } \\
\text { with setbacks in saving. }\end{array}$ & - The Story of Hellen & $\begin{array}{l}\text { 2. Explore challenges and } \\
\text { possible setbacks in } \\
\text { saving-10 minutes }\end{array}$ \\
\hline
\end{tabular}




\section{activity 1}

\section{REVIEW THE SAVINGS PLAN}

(5 MINUTES)

Ask:

$\int$ An idea about how you are going to accomplish your savings goals and the action you will take to achieve those goals is called what?

[A savings plan.]

What is an example of a savings plan and list the actions you are going to take to achieve your savings goal?

Listen to examples from the girls in the group, congratulate them on their hard work and encourage

them not to give up.

\section{activity 2}

\section{EXPLORE CHALLENGES AND POSSIBLE SETBACKS IN SAVING}

(10 MINUTES)

Say:

Saving is not always as easy as it seems and sometimes things may not go as planned. In the previous sessions, we talked about making a savings plan which helps us achieve our saving goals. When we make our savings plan, we must always be aware of the challenges and possible setbacks to our savings plan.

Ask:

\section{$\int$ What is a setback?}

[A setback is an event or a happening that prevents your plan from working out. This is likely to affect your plan.]

What are some of the examples that may be a setback to a savings plan?

[Some examples:

- Tina plans to be saving KR 10 per week from her school pocket money, but suddenly, the school undergoes an indefinite closure due to a chicken pox outbreak in the school community, and no school means no pocket money.
- During the holidays, Mwiche manages to raise KR 80 to buy a Girl Scout uniform at the beginning of the term by helping out at her auntie's salaula stand in the market. Suddenly, she discovers the price of the uniform has gone up by KR 30.

- Mary, who lives with her mother and three younger siblings, has been saving KR 15 each week so that she has money to start a clothes selling business in the market. However, her house gets broken into and now she needs to help her mother fix the door/lock and replace the furniture that was stolen.] 


\section{activity 3}

\section{THE "FALLBACK PLAN": DEALING WITH SETBACKS IN SAVING}

(25 MINUTES)

\section{Explain:}

$\bigcirc$ We are going to listen to and discuss a story of a girl who had a good savings plan but things did not work out as she expected. But most importantly, we are going to discuss how she learned to deal with setbacks to her savings plan.

Read out loud the story of Hellen (found on the next page).

\section{Ask:}

\section{What were Hellen's saving goals?}

[To raise money as a supplement toward her school transportation.]

\section{What was Hellen's savings plan?}

[She decided to miss lunch every day and save the money to raise capital for her small business. She planned to raise KR 35 capital for a small business in two weeks, then use the money to start selling frizits at school.]

\section{What were the setbacks in Hellen's savings} plan?

[It wasn't easy for Hellen to miss lunch at school; it took longer for Hellen to raise the capital than she had initially planned. After raising the capital, she was faced with an emergency to pay for her sister's medication when she fell ill. When she begun making money, from selling frizits, the weather changed and she could no longer make money from the business.]

\section{How did Hellen overcome her various} setbacks?

[- Difficulties in raising capital-readjusted her timeframe for the savings goal because she was not able to save as much each week as she had initially planned.

- After using her savings for an emergency she began saving all over again.

- Change of weather, no business-she readjusted her savings plan and changed her line of business.

- Overall-SHE KEPT SAVING AND DIDN'T GIVE UP!]

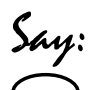

Say:

One thing that will help in dealing with setbacks in savings is having a "fallback plan." This plan involves five simple steps that will help you manage a setback in your saving:
1. Revisit your savings plan.

2. Explore and list your available options.

3. Weigh your options and compare them to your savings goal.

4. Choose your fallback plan.

5. Continue saving and don't give up! 


\section{THE STORY OF HELLEN}

Hellen is a 14-year-old girl living with her older sister in [name of local community]. Her school is far from home so she gets on a bus twice a day to get to school and back home. Her older sister has to give her transportation money for school and lunch and her sister does not always have the money. As a result, Hellen sometimes misses school and her grades suffer because she gets behind in school work.

Lately, Hellen has been thinking of how she can make her situation better and not let her need for transportation money get in her way of attaining an education. She decides to make a savings plan to raise some money as a supplement toward her transportation costs. To do this, she starts a small business selling frizits (ice blocks) at school. Hellen needs capital of KR 35 to buy an initial box of frizits. She plans to raise this money by saving her school lunch money for two weeks. However, this takes much longer than she expected because sometimes her sister has no money to give her for lunch. She perseveres and manages to save KR 35 in four weeks, as opposed to the two weeks she initially planned. Just before Hellen sets off to by the ice blocks, her sister falls ill and she has to use the KR 35 for medicine. At least she went to her savings and not Patrick, her 27-year-old neighbor who gives her money sometimes.

Hellen begins saving for her capital again and this time it takes even longer (six weeks). She finally manages to buy the box of frizits to sell at school. The sales are very good in the beginning and her transportation money is covered for weeks to come. However, once the weather changes into the cold season, everyone stops buying frizits.

To keep her business alive so she can keep saving, Hellen decides to reinvest her capital in selling Jiggies and is able to make enough money not only to supplement her transportation to school, but also she also saves enough to buy small school requirements that she could not afford before. 
14) Your Own Money vs. Someone Else's Money

\begin{tabular}{|c|c|c|c|}
\hline $\begin{array}{l}\text { OBJECTIVES } \\
\text { By the end of this session, participants } \\
\text { will have: } \\
\text { - Differentiated between one's own } \\
\text { money and borrowed money. } \\
\text { - Identified characteristics of borrowed } \\
\text { money. } \\
\text { - Understood the importance of being } \\
\text { in control of one's own money. }\end{array}$ & $\begin{array}{l}\text { MATERIALS } \\
\text { None }\end{array}$ & $\begin{array}{l}\text { TIME } \\
40 \text { MINUTES }\end{array}$ & $\begin{array}{l}\text { ACTIVITIES } \\
\text { 1. Distinguish between borrowed } \\
\text { money and your own money } \\
-10 \text { minutes } \\
\text { 2. Understanding the responsibilities } \\
\text { of borrowing }-20 \text { minutes } \\
\text { 3. Understanding the importance } \\
\text { of gaining control over your own } \\
\text { money-10 minutes }\end{array}$ \\
\hline
\end{tabular}


activity 1

\section{DISTINGUISH BETWEEN BORROWED MONEY AND YOUR OWN MONEY}

\section{(10 MINUTES)}

NOTE TO TRAINER: For the game below, make sure to keep the group moving. If you stop to discuss each statement, the time needed for the activity will increase greatly. Keep the group moving to keep the energy of the game!

\section{Explain:}

We have spent a lot of time learning about why it is important to save and how to increase our savings. But sometimes we also borrow money. In the next few meetings, we will try to understand the difference between money we save and money we borrow.

Let's start by making a line. Stand up!

Show the girls where you want them to stand to form a line.
Say:

I am going to tell you different amounts of money and where they came from.

For each one, you must decide if that money is borrowed or if it is your own money. If you think it is borrowed, step to the left. If you think it is your own money, step to the right.

When there is disagreement, discuss the different opinions and clear up any confusion about bor-

rowed money and money that belongs to someone. Read the following descriptions:

- Your mother gives you KR 80 for transportation [own]

- Your sister lends you KR 15 to buy body lotion [borrowed]

- You sell your mobile phone for KR 150 to a friend [own]

- You wash your neighbor's clothes for KR 50 [own]
- At the Kantemba milk costs KR 5 and you buy it on credit

[borrowed]

- You go to see a movie with a friend and she lends you money for the ticket [borrowed]

- For a trip, your aunt gives you a gift of KR 200 [own]

- You take KR 20 from your home bank under your bed to buy sanitary pads [own]

- You take piecework and earn KR 6 for selling 10 bags of groundnuts to buy material for a domestic science project at school [own]

- Your neighbor lends you KR 30 to buy baking flour for making vitumbuwa (fritters) for sale at the school grounds [borrowed]

$\uparrow$ Borrowed Money $\uparrow$

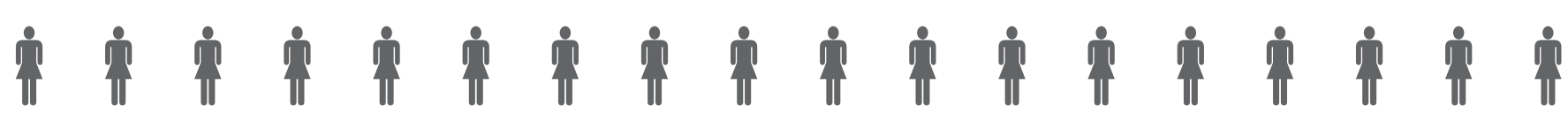

$\downarrow$ Own Money $\downarrow$ 


\section{activity 2}

\section{UNDERSTANDING THE RESPONSIBILITIES OF BORROWING}

(2O MINUTES)

Divide the group into two teams and give each team a name. Use something familiar or humorous for the teams: names of animals ("the elephants" vs. "the giraffes") or well-known musicians (such as "Mampi" vs. "Dandy Crazy"). Refer to the list of "Questions about Borrowing Money" on the next page.

\section{Explain:}

$S$ I have a list of questions about borrowed money, and we will play a game to talk about the two.

If you have blackboard space, or a blank piece of flipchart paper, write the rules down before you explain them. If you don't, explain the rules clearly and ask one or two girls to repeat them to make sure everyone understands.

Say:

When I read the question, both teams will have one minute to discuss the answer.

The team whose "turn" it is will have the first chance to answer

- If they are right, we will move on to a new question for the other team.

- If they are wrong, the other team will have a chance to answer before their turn.

We will start with Team 1. Ready?
Congratulate both teams! Explain that the point of the game is to understand that money comes with responsibility-paying it back, paying it back on time, and paying it back with any interest that might be charged.

\section{Conclude by asking:}

5 What are some advantages of borrowing money?

[Some possible answers include: you have immediate access to money; you can buy what you want right away; you will not miss the chance to buy something or make an investment at a good price.]

\section{What are some disadvantages?}

[Some possible answers include: borrowing costs money because of interest and/or fees; if you fail to repay there are consequences; there is pressure to repay on time; if there is an emergency you may never be able to repay.]

What questions do you have about

borrowing money? 


\section{QUESTIONS ABOUT BORROWING MONEY}

- Why is borrowed money different from your own money?

[Borrowed money must be paid back; you have more flexibility and control with your own money.]

- When you borrow money, why do you have to pay it back?

[Because the money does not belong to you; the money belongs to the person or institution who lent it to you, who expects to get it back.]

- If you borrow money from a friend, do you have to repay it?

[Normally, yes. Sometimes a family member or friend will end up giving you the money-that is, giving you permission to not repay the loan. But you should never assume that this will happen, and always plan to repay or return whatever you borrow!]

- When you borrow money from a friend, can you decide when to pay it back?

[Maybe. If you borrow from a friend or relative, they may be very flexible about when you need to return the money. You will have to discuss the terms and schedule before you borrow the money.]
- When you borrow money from a financial institution (like a bank) or a savings group, can you decide when to pay it back?

[No. If you borrow from a financial institution or a group, you will most likely have a payment schedule to repay in installments that are due each week or each month until the full amount is repaid.]

- Does it cost you anything to borrow money from a friend or family member?

[It depends. When you borrow from a friend or family member, she may not ask you to pay interest on the loan. Again, this is something you will have to discuss before you borrow the money.]

- Does it cost you anything to borrow money from a financial institution or a savings group?

[Yes. Most lenders charge you something to use their money (this amount is "interest").]

- If you borrow money and a thief then steals it, do you still have to repay the money?

[Yes!] 


\title{
activity 3
}

\section{UNDERSTANDING THE IMPORTANCE OF GAINING CONTROL OVER YOUR OWN MONEY}

\author{
(10 MINUTES)
}

\section{Explain:}

Now that we have talked about one's own money and other people's money, we are going to look at why it is important to ensure that other people respect your own money and understand that you have the right to make your own decisions over it.

Let's begin by thinking of some of the ways that sometimes make us feel we don't have control over our own money

Use the following questions to prompt girls to think very thoroughly about situations they feel lessen their decisionmaking over their own money. Aim to find out the girls' perceptions of who can have the right to access their money. Use a blackboard or flipchart to list the girls' ideas as they offer them.

\section{Read:}

Lulu has KR 25 and plans to use part of it to go and watch a variety show at her school on Saturday and the rest to buy cooking ingredients for her domestic science assignment. Instead, her father gets the money from her pillow and gives it to a visiting uncle as transportation money to return to his hometown.

Ask:

How can she make her father understand that he needed to discuss with her first before giving the money to someone else and without her permission?
Read:

5 Nsofu keeps some money in the bank and often deposits small amounts of money whenever she has it. She hopes to raise some money so she can save up for capital to start a new business. Nsofu's mother knows she keeps some money in the bank and, instead of saving it for Nsofu's business, her mother tells her to save the money for the family to buy a new gas kerosene oven for making fritters at the market.

Ask:

How can Nsofu make her mother understand that she plans to use the money for something else?

\section{Read:}

Sipo and Chama are best friends and spend a lot of time selling tomatoes at the market together. They know a lot about each other and share almost everything. Sipo knows that Mwangala, one of their other friends, borrowed KR 50 from Chama two weeks ago. Mwangala raises the money and decides to return it to Chama but finds Sipo instead. She gives the money to her knowing that they are best friends but insists that she give it to Chama upon her return. Sipo decides to use the money without Chama's permission.

Ask:

S How does Chama make Sipo understand that though they are best friends, she had no right to use the money without her permission?
Explain:

5 Many times we may feel like our own money is not really ours because either other people decide on our behalf what we should do with it or simply have access to it without our permission. These can be our friends, our parents, our siblings, or boyfriends who often feel they should have access to our money or make decisions on our behalf. While it is important to help out at home or take on other responsibilities moneywise, it is also important that people around you know and respect the fact that they have the responsibility to discuss your money with you and that you have the right to make the final decision.

Ask:

What can Lulu, Nsofu, and Chama do to change their situation?

[Communicate clearly their saving goals and what they plan to use the money for. In this way, others will gain an appreciation of what the money is intended for.]

[Be open and set limits on other people's access to their money. In this way, others will understand that they don't have the right to access it.] [Clearly and openly communicate how far they can go in taking up money responsibilities. In this way they won't be raising other people's expectations too high.]

[Show responsibility and assertiveness in the decisions they make over the use of their own money. In this way, others will respect them and set their own limits to accessing their money.] 


\section{Talking About Money}

OBJECTIVES
By the end of this session, participants
will have:
- Listed who they talk about money
with and what they talk about.
- Described the possible outcomes of
discussions about money.
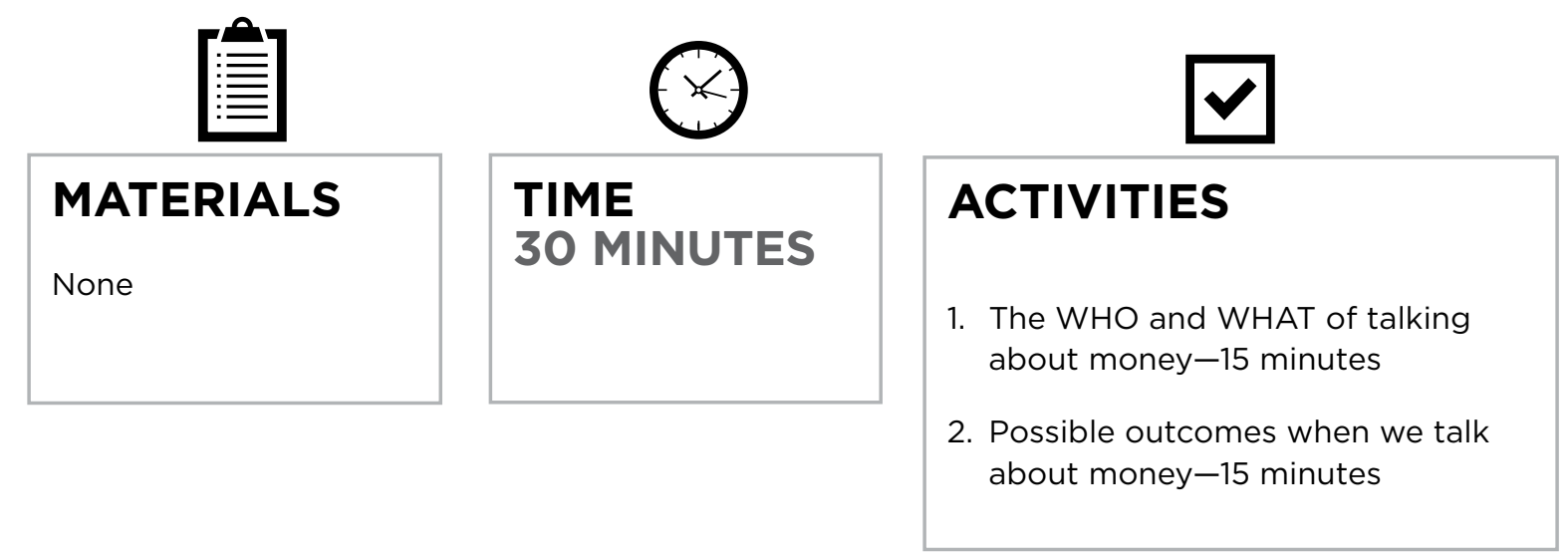


\section{activity 1}

\section{THE WHO AND WHAT OF TALKING ABOUT MONEY}

\section{(15 MINUTES)}

Tell the girls that in this learning session, they will play the game "Stand Up Clap Your Hands."

Explain that you will start by thinking about WHO we talk to about money. You will give them people or a person, and they should stand up and clap their hands if they talk to that person/people about money. Have fun, and lead this in a lively manner!

Say:

Stand up clap your hands if you talk to:
1. Parents!
6. Your schoolmates!
2. Siblings
7. Your uncles!
3. Shopkeepers!
8. Your aunts!
4. Your boss!
9. Your neighbors!
5. Your friends!
10. Your grandparents!

Ask other groups if they have other examples of WHO to add. Then, move on to the second part of the game.

Explain that you will now think about WHAT you talk to these people about in terms of money.

Say:

Stand up clap your hands if you talk about:
1. School fees!
5. Bus fare!
2. Pocket money!
. Prices of products!
3. Things to buy for
7. Saving!
the family!
8. Borrowing money!
4. Food!

Give girls a chance to add any other examples of WHAT they talk about.

Tell girls that for the final part of the game, they will think about how they feel when they talk about money.

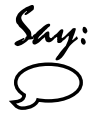

Stand up clap your hands if, when you talk about money, you feel:
1. Confident
2. Happy!
3. Nervous!
4. Angry!
5. Hopeful!

Give 2-3 volunteers the chance to add any examples.

Then, say:

5 We talk about money with many people in many situations. However, money can be one of the most difficult topics to talk about with other people. Even so, as we saw in the answers to our questions, we still talk about it with many people for many reasons. In the next few sessions, we will learn about some ways to talk about money that make the conversation easier. 


\section{activity 2}

\section{POSSIBLE OUTCOMES WHEN WE TALK ABOUT MONEY}

\section{(15 MINUTES)}

NOTE TO TRAINER: In this step, you will introduce girls to three different outcomes that can happen when we talk about money. To liven up the session, you (or girl volunteers) can act out the three scenarios in the out comes and ask the girls to guess which is which rather than just reading them out loud. Be sure to add time or use another meeting time if you choose that option.

Say:

Our goal together is to find ways to make talking about money easier and more effective. We'll start by identifying the possible outcomes-or results-of talks about money.

Ask:

5 When we finish talking about money with someone, is everybody involved always happy with the outcome?

Girls will most likely answer "no."

Say:

When we talk about money, sometimes both people involved end up happy as each gets something they want. Sometimes neither gets anything-both lose. And sometimes, one person gets something she wants and the other person does not. When we talk about money, there are winners and losers.

Explain to the girls that you will give them a few examples. Tell them that their job is to listen and decide who in each story is happy with the outcome.

\section{Possible Outcomes when Talking About Money} Win-Win

This is the best outcome in any discussion about money. Both people (or groups) involved in the discussion get something or everything they want or need. They both have a positive feeling at the end of the discussion, and are willing to talk about money again in the future.

\section{Lose-Lose}

This is the worst possible outcome in a discussion about money. In this outcome, the two people (or groups) cannot agree. In the end, neither person (or group) involved in the discussion gets what they wanted. They may not be willing to talk about money again in the future.

\section{Win-Lose / Lose-Win}

In a win-lose or lose-win situation, one person (or group) gets what she wants and the other gets nothing. When this happens, the loser might be less likely to want to talk to the winner about money again in the future.

- $\cdots \cdots$

\section{Outcome:}

An outcome is the result of something. When we are talking about money, we use outcome to mean the result of the discussion.

\section{Lose-Lose Outcomes}

Read/tell Situation 1:

5 A customer is discussing the price of a blanket with a vendor in the market. They cannot agree on the price, and the customer leaves the market without buying anything from the vendor.

Ask:

5 Who was the winner at the end of this discussion? [Neither person.]

Who was the loser? [Both people.]

When someone answers correctly, explain "lose-lose" outcomes:

\section{Say:}

5 Sometimes, no one involved gets what he or she wants. This type of outcome is called "lose-lose."

Ask:

What is another example of a "lose-lose" outcome when we talk about money?

[For example: You and a neighbor want to buy a pack of used clothes and sell them together. However, if you cannot agree on how much each of you will spend, you both lose. Neither of you can make that investment and benefit from it. It is a lose-lose situation.]

Give 1-2 girls the opportunity to give an example to check their comprehension. Make sure the examples they give are truly "lose-lose" situations, then move on to win-lose / lose-win outcomes.

(activity 2 continued on next page) 


\section{activity 2 (continued)}

\section{Win-Lose / Lose-Win Outcomes}

\section{Read/tell Situation 2:}

$\bigcirc$ Jackline wants her sister Julie to do the housecleaning for her so that Jackline can spend time with her new boyfriend. Julie asks Jackline to pay her, but Jackline refuses. When Jackline threatens to hit Julie, Julie gives in and agrees to do the housework for nothing.

Ask:

5 Who was the winner in this discussion? [Jackline] Who was the loser? [Julie]

When someone answers correctly, explain "win-lose/ lose-win" outcomes:

Say:

Often, one person in the discussion gets what he or she wants, and the other gets nothing. These outcomes are called "win-lose" or "lose-win." In those situations, the loser might be less willing to talk with the winner about money again!

Ask:

What is another example of a "win-lose/losewin" outcome?

[For example: You need money immediately and cannot wait. You borrow money from a friend, and she will lend you money ONLY if you agree to pay back twice the original amount In that case, you lose because you do not have time to wait, and your friend wins as she gets a large payback. It is a lose-win situation.]

Give 1-2 girls the opportunity to give an example to check their comprehension. Make sure the examples they give are truly "win-lose/lose-win" situations.

Finally, move on to win-win outcomes.

\section{Win-Win Outcomes}

\section{Read/tell Situation 3:}

5 Chilombo wants to buy a bicycle. She discusses with a salesman in the market the price of a bike that is on display, but she cannot get the price low enough. She is about to leave when the salesman asks Chilombo to wait for a moment, as he has just remembered another bike he has behind his market stall. Chilombo likes it and it is in her price range. Chilombo decides to

Ask: buy the second bike.

\section{Who was the winner at the end of this discus-} sion? [Both.]

When someone answers correctly, explain "win-win" outcomes:

Say:

This outcome is a "win-win" situation. Both sides got something they wanted or needed, if not everything. In win-win outcomes, everyone comes away with positive feelings and they are likely to talk to each other about money again.

Ask:

\section{What is another example of a "win-win"} outcome?

[For example: You want to buy food from a saleswoman, and you negotiate a good price together You are happy with your purchase, and your savings, and you recommend that your friends and family buy things from the same saleswoman. She gets more business because of her good offer to you, and you saved some money. You both win, and it is a win-win situation.]

Give 1-2 girls the opportunity to give examples to check their comprehension.
Ask:

\section{5 - Which of the three outcomes is the pre-} ferred outcome? [Win-win.]

- Why? [Win-win, because both people in the situation win. They both have positive feelings, and are willing to work together again in the future.]

- Let's think back about the win/lose situation with the sisters Julie and Jackline-how could we turn that into a win-win situation? [Example-Julie agrees to do the housework one day so that Jackline can see her boyfriend if the following week Jackline does Julie's housework one day so she can go and spend time with her friends.]

- Let's think back about the lose/lose situation with the customer and vendor in the market trying to buy and sell a blanket-how could we turn that into a win-win situation? [They agree on a price between what each one started with; the vendor shows the customer a cheaper blanket which she then can afford and decides to buy.]

\section{In conclusion, say:}

Until we meet again, pay close attention to the discussions that happen around you every day: at home, with friends, in the market. Ask yourself: Are there winners and losers in this discussion? Do both sides end with something they want? Do both seem happy and satisfied? Or, do they seem angry?

Congratulate the girls on a job well done! Remind them that you will ask about outcomes in the next session. 


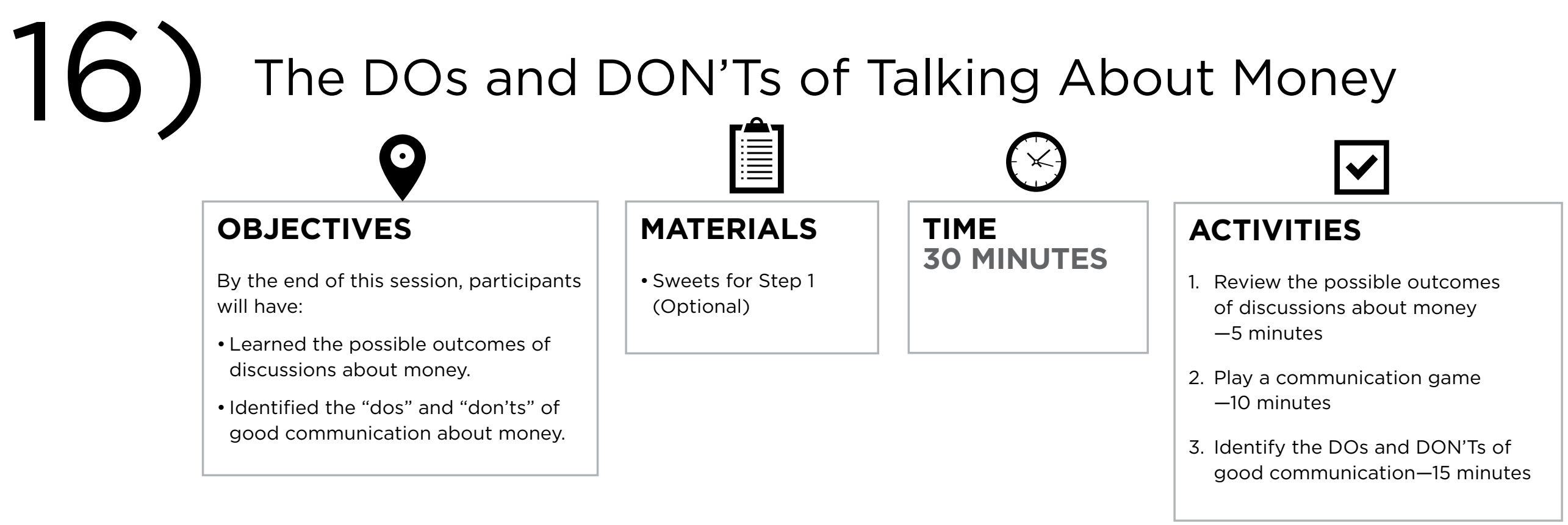


activity 1

\section{REVIEW THE POSSIBLE OUTCOMES OF DISCUSSIONS ABOUT MONEY}

\section{(5 MINUTES)}

NOTE TO TRAINER: If possible, bring sweets for

this step. Award them to girls for remembering the

types of outcomes that are possible when talking

about money.

\section{Stast loy asking:}

$\Omega$ What types of outcomes are possible when we talk about money?

[Lose-lose, win-lose/lose-win, win-win.]

Instruct the girls to talk in groups of three with the girls sitting next to them. Ask the girls to follow the instructions below.

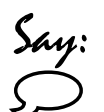

In the last session, I asked you to pay attention to "talking about money" in daily life.

Now, take a moment in your groups and

describe a discussion you experienced or saw. Also, tell the other girls what type of outcome came from that discussion or talk.

After three minutes, ask for 2-3 short examples to check that girls have remembered the concept correctly. 


\section{activity 2}

\section{PLAY A COMMUNICATION GAME}

(10 MINUTES)

Introduce the topic of communication with a game called "Telephone." You will play this game in a series of groups. Make sure that each girl gets a chance to participate in one of the groups!

Call six girls to the front to participate in the first round. This will serve as a demonstration for everyone. Tell the girls that together, they are a telephone line. Help girls to form a line.

Explain that you will whisper a short phrase into the first girl's (Girl 1's) ear. Girl 1 will then do her best to repeat the phrase to Girl 2. Then, Girl 2 will repeat the phrase to Girl 3, and so on until you reach the end of the line.

Each girl can say the message ONLY once!
The girl at the end of the line will then say what action she thinks she heard. There is no repeating of the message

For the demonstration, whisper the phrase "Start saving by making a savings goal" into the first girl's ear. By the end, the message should be confused and different

When you have finished the demonstration, separate the girls into groups of equal size. Whisper messages into the first girl in each group's ear. If time allows, you can let the girls come up with their own messages.

\section{Phrases for Telephone}

1. Always pay yourself first.

2. Don't forget to control your expenses

3. Know the difference between needs and wants

When you have finished all the phrases,

Ask:

What happened between the beginning and the end of the line?

[The message changed or was completely lost.]

\begin{tabular}{|c|c|c|c|c|c|c|}
\hline $\begin{array}{c}\text { Trainer } \\
\text { whispers } \\
\text { original } \\
\text { message }\end{array}$ & Girl 1 & Girl 2 & Girl 3 & Girl 4 & Girl 5 & $\begin{array}{c}\text { Final girl } \\
\text { tells the } \\
\text { message she } \\
\text { heard }\end{array}$ \\
\hline
\end{tabular}


activity 3

\section{IDENTIFY THE DOS AND DON'TS OF GOOD COMMUNICATION SKILLS}

(15 MINUTES)

Say:

Clear communication is very important when it comes to discussing money and financial topics. We don't want our messages to get jumbled or changed or misunderstood because we don't communicate well-especially when we are talking about money, and we want to achieve a win-win outcome.

Based on your own experiences:

- What can happen during a conversation about money to cause a win-lose or loselose outcome?

[One person gets angry; one or both people refuse to listen to the other person; one or both is not flexible or willing to see the other person's point of view.]

- If we want a win-win outcome, what are some rules we should follow when we talk about money?

Allow several girls to give their opinion. Add any of the DOs below that they do not mention. When you have completed the list, assign each girl one of the following DOs. If you have a blank flipchart or blackboard available, prepare these ahead of time. (There will be more than one girl for each DO.)

\section{DOs for Talking About Money}

- Listen to the other person

- Try to see the other person's point of view

- Show respect

- Be flexible

- Clearly state what you want

\section{Then ask:}

5 What should you NOT do when trying to communicate successfully?

Again, allow several girls the opportunity to answer. Add any of the DON'Ts below that they do not mention. When you have completed the list, assign each girl one of the following DON'Ts. If you have a blank flipchart or blackboard available, prepare these ahead of time. (There will be more than one girl for each DON'T.)

\section{DON'Ts for Talking About Money}

- Get angry

- Be rude or insulting

- Reject the other person's ideas without listening

- Lock yourself into one position

- Raise your voice
End by practicing the DOs and DON'Ts to make sure everyone remembers them. Allow girls to first repeat the DOs they were assigned, and then the DON'Ts.

NOTE TO TRAINER: If you are using this session and have more time, or if you want your girls to work together outside of their safe spaces group time, you can use this extra activity:

Ask girls to work in five groups. Each group will be assigned one communication DO. They must come up with a song together about that DO. They can use a popular melody and change the words, or write their own brand new song.

Give every group a chance to sing their song when they are finished! 
17) Resolving Conflicts About Money

OBJECTIVES
By the end of this session, participants
will have:
- Recognized the DOs and DON'Ts of
good communication in a real-life
experience.
- Identified good communication skills
in a sample dialogue.
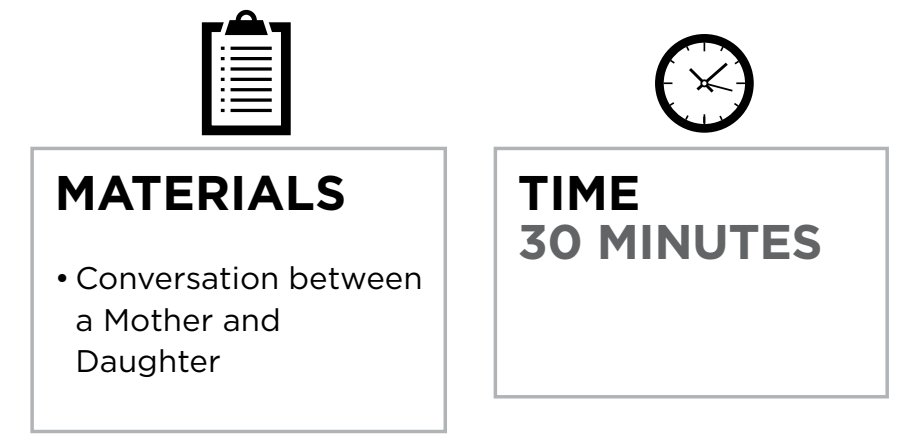

TIME

30 MINUTES

a Mother and

Daughter 


\section{activity 1}

\section{APPLY THE DOS AND DON'TS TO REAL LIFE}

\section{(10 MINUTES)}

Ask girls to repeat the DOs and DON'Ts of talking about money from the last meeting. Because each girl was assigned one to remember, you should easily be able to review them all. Ask for volunteers to make up a gesture that represents each DOs and DON'T of talking about money. Then have everyone call out the DO or DON'T and repeat the gesture. You can show an example for the first one (e.g. place your hand behind your ear for "Listen to the other person."

\section{DOs for Talking About Money}

- Listen to the other person

- Try to see the other person's point of

view

- Show respect

- Be flexible

- Clearly state what you want

\section{DON'Ts for Talking About Money}

- Get angry

- Be rude or insulting

- Reject the other person's ideas without listening

- Lock yourself into one position

- Raise your voice

\section{Say:}

Think about the DOs and DON'Ts, and think of a situation in which you did not communicate well with a parent, teacher or friend.

What could you have done differently in that situation?

Instruct girls to talk with someone sitting next to them for 2-3 minutes. Then, allow 3-4 girls to give their examples and solutions.

\section{Explain:}

$\int$ People often disagree about issues that involve money. Many of you are starting to have more responsibility for yourself and your financial situation at home, at school, or in your work. That means you will probably have more discussions-and even more conflictsrelated to money. Today we are going to talk about and practice resolving conflicts about money. 
activity 2

\section{EXAMINE A CONVERSATION BETWEEN A MOTHER AND A DAUGHTER}

(2O MINUTES)

NOTE TO TRAINER: Ask a girl who can read well (one of the girls in your group or even another volunteer) to do this role play with you BEFORE the group meeting. Spend a few minutes preparing so that the role play goes smoothly. If possible, use a scarf or hat as a costume to show girls that you are playing a different character. Further note that this conversation is presented as Option one and Option two. Choose an option that is best suits where you are facilitating the safe space (i.e., choose Option one if you are in a more urban setting or Option two for a rural setting)

If possible, make photocopies of the role play as a handout for girls and distribute them during the session.

Explain to the girls that they will now watch some of the communication skills from the last meeting in action and present the role play "A Conversation Between a Mother and Daughter" (see the following page).
At the end of the role play,

Ask:

What is the daughter's goal for the discussion with her mother?

[To get a mobile phone.]

\section{What is the mother's reaction to her} daughter?

[At first, she is angry. However, with the daughter's calm explanation, the mother and daughter come to an agreement.]

\section{What communication skills from our DOs} and DON'Ts did you notice?

[The daughter showed respect, she didn't get angry, she understood her mother's point of view, she was flexible, and she clearly stated what she wanted. She even proposed a new solution when she saw that the first one would not work.]
NOTE TO TRAINER: If time remains, or if your girls work well together outside of the savings group, you can separate them into five groups and assign each group to prepare one of the role plays in Session 18 for next week. (See page 81.)

\section{(activity 2 continued on next page)}




\section{activity 2 (continued)}

\section{(OPTION ONE - URBAN)}

\section{A Conversation Between a Mother and Daughter}

Daughter: Hello, mother. I want to talk to you about something important. Do you have a few minutes now?

Mother: I have to go out soon to work in my shop. Let's make it quick!

Daughter: Mother, now that I am older and part of a group, I am learning many new things. I have to travel across town for my group and for school. l'd like my own mobile phone. I know they are expensive but...

Mother: (cutting her off) You always want something-usually something expensive! You know money is tight in this family!

Daughter: But mother, a mobile phone wouldn't just be for me. Now that Sampa and Chola, my younger brothers, will be going to school, and I have to collect them at the end of the day, and do errands for you and father.

Mother: $\quad$ Young lady, you do not seem to realize that there are many things that I need to buy for our household. I have to decide how to spend this money in everyone's best interest.

Daughter: I'm sorry. I didn't mean to make you angry. I know it is difficult to manage so many demands on our budget. I can wait to get a mobile phone. Do you think it would be possible for me to come up with a plan to buy a mobile phone in the future? I'm saving money now, and I am earning some money helping Mama Moses in her salon. It isn't much, but if I save, I can have enough for half of the price in two months. If I am able to save that money, would you consider helping me pay for the rest?

Mother: I suppose I could consider that. But don't expect me to pay for your talk time!
(OPTION TWO - RURAL)

\section{A Conversation Between a Mother and Daughter}

Daughter: Hello, mother. Can I talk to you about something important? Do you have a few minutes now?

Mother: I have to go out soon to work at the stand in the market. Let's make it quick!

Daughter: Mother, now that my baby Chimwemwe is older and not breastfeeding any more, I'm thinking it's time I went back to school. Most of the girls in our girls group meetings have gone back to school even after having their...

Mother: (cutting her off) We have had that conversation before. How much more explaining do I have to do to make you understand that this family is not making enough money for all of you to be in school. It's already hard trying to keep your brothers in school. It just has to wait until there is enough money. Besides you being older, you must be doing something and contribute toward helping the family get around these problems. You know that school costs way more than that.

Daughter: But mother, we have been putting my school on hold for three years now. I'm not getting any younger. All my friends are almost completing school now. Does this mean l'm never going back to school? Besides, going back to school is the only way I can relieve you of having to take care of both me and my child too in future.

Mother: Young lady, you do not seem to realize that there are many things that I need to buy for our household. I have to decide how to spend this money in everyone's best interest.

Daughter: I'm sorry. I didn't mean to make you angry. I know it is difficult to manage so many demands on our budget. I can wait to get back into school. Do you think it would be possible for me to come up with a plan to help you pay for my school fees? I'm saving money now, and I am earning some money helping Mama Moses in her salon. It isn't much, but if I save, I can make enough to pay half of my schools fees. If I am able to save that money, would you consider helping me pay for the rest?

Mother: That's a good idea. I suppose I could consider that. But just remember that we may need to cut down on many other expenses that are not priority right now. 
18) Role Play Resolving Conflicts

\begin{tabular}{|l|}
\hline OBJECTIVES \\
By the end of this session, participants \\
will have: \\
- Practiced using communication skills \\
to resolve conflicts through role \\
plays. \\
- Identified more than one solution to \\
sample conflicts.
\end{tabular}
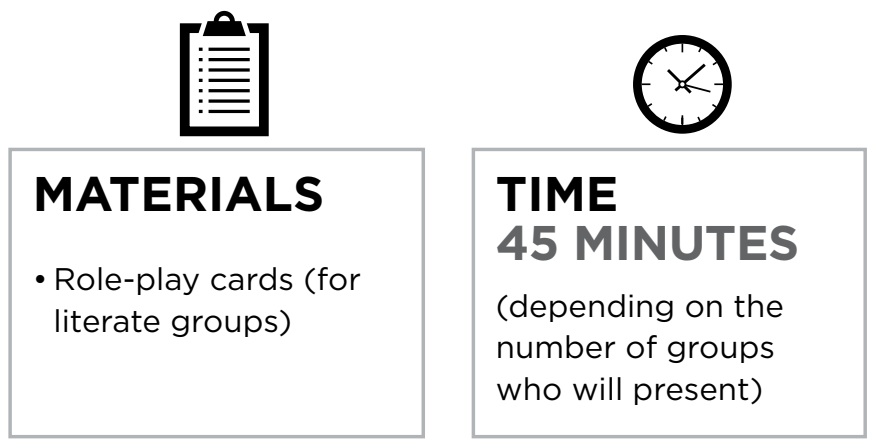

ACTIVITIES
1. Role play a conflict and find a
solution-45 minutes




\title{
activity 1
}

\section{ROLE PLAY A CONFLICT AND FIND A SOLUTION}

\author{
(45 MINUTES)
}

NOTE TO TRAINER: If you already assigned these role plays in the previous meeting with girls, or if you are leading a longer meeting, you can go ahead and get started with role play presentation immediately and skip the introduction below.

If you are doing these role plays in one session, you must be very careful to limit the preparation and presentation time so that you have enough time for everyone to present

Divide girls into groups of four. (There are five role plays. If you have more than 20 girls, you can give the same role play instructions to more than one group.) You can photocopy role plays in advance and give them to the girls, or show/explain the instructions on the following page.

\section{Explain:}

$\int$ I will assign each group a role play that describes a conflict about money. First, each group should decide together on a win-win solution that will solve your conflict. Then you will make up a role play between the people described and the solution you have chosen. At least one of the characters in the role play should try to demonstrate good communication skills.

You have only five minutes to prepare a three-minute role play. Good luck!
NOTE TO TRAINER: Examples of win-win

situations are provided for you on the following page so that you can help girls if they are having trouble deciding what a win-win situation could be for their role play.

After each presenting group has performed its role play,

Ask:

5 What communication skills did you notice among the actors in the role play?

What was the solution they arrived at?

What are other possible solutions to this conflict?

Say:

Today we have seen different ways of resolving conflicts. In real life, not all discussions about money result in a win-win outcome. Although we all hope for a win-win outcome, sometimes these are impossible due to the personalities involved, or the emotions of the moment. However, communicating with confidence is the starting point for achieving good outcomes when talking about money.
As we said in our DOs and DON'Ts, if we explain what we want clearly and listen to the other party's needs, keep calm, and look for a compromise, we can negotiate our way to a win-win outcome more often than not.

(activity 1 continued on next page) 
colvity 1 (continued)

\section{CONFLICTS ABOUT MONEY: ROLE PLAYS}

1. Corrinne helps her grandmother on Saturday mornings at her hotel near the market. She wants to keep this money herself. But her mother insists that Corrinne give her all of the money to help with household expenses. [Corrinne can discuss the reasons that she is saving money with her mother, and they can agree that Corrinne keep half of the money, and give the other half to her mother.]

2. Michelo has a motorbike which he uses to transport customers every day after school. He is saving to move to Kabwe from Chibombo. But his parents oppose his plans to leave their rural home. They need him at home to help with expenses.

[Michelo agrees to stay and help his parents for the next year, as long as he can save some money for himself. He can show them that he sees their side of the story, and he can plan to move after the agreed amount of time.]

3. Fatima gets money each week from her parents for her bus fare and lunches at school, and saves what is left over with her savings group. When her parents learned that Fatima had a little to save at the end of each week, they got angry. They threatened to reduce her allowance, but Fatima wants to keep a little money as her own.

[Fatima can invite her mentor with her savings program to talk with her parents about the benefits of saving. She can present to them the advantages of saving, and the goals that she has set out for savings. She must make sure to explain that this will save her parents money in the long term.]

4. Nosiku and Pamela are sisters who work in the same market stand every day. They get money from their parents to take the bus to the market. However, Pamela now wants them to walk, and save and split their transportation money.

[Pamela can explain some goals that she and Nosiku can save for in the future and how much money they will need to achieve them. Nosiku and Pamela can then decide on a goal together, and agree to walk some of the time.]

5. Emily recently worked for a neighbor for five days. However, when she went to collect her earnings, the neighbor said she had only worked for four days. Emily wants to resolve the situation and still collect her earnings.

[Emily can find someone else who saw her working on each of the five days to back up her story. She can tell the neighbor that she is a good worker, and that she wants to continue to do good work for him and that in order to work well, she must be paid.] 
19) Our Journey to Good Money Management

\begin{tabular}{|c|c|c|c|}
\hline $\begin{array}{l}\text { OBJECTIVES } \\
\text { By the end of this session, participants } \\
\text { will have: } \\
\text { - Reflected on dreams for the future. } \\
\text { - Revisited key topics from the FE } \\
\text { curriculum. } \\
\text { - Celebrated the completion of the FE } \\
\text { course. }\end{array}$ & $\begin{array}{l}\text { MATERIALS } \\
\text { - Ball of string } \\
\text { - Flipchart paper }\end{array}$ & $\begin{array}{l}\text { TIME } \\
45 \text { MINUTES }\end{array}$ & $\begin{array}{l}\text { ACTIVITIES } \\
\text { 1. Dream big-Reflecting back } \\
-10 \text { minutes } \\
\text { 2. Revisit key topics from the } \mathrm{FE} \\
\text { curriculum-20 minutes } \\
\text { 3. Let's celebrate our } \\
\text { achievement-15 minutes }\end{array}$ \\
\hline
\end{tabular}




\section{activity 1}

\section{DREAM BIG-REFLECTING BACK}

\section{(10 MINUTES)}

NOTE TO TRAINER: If you have a blackboard or blank flipchart paper available, use them for this session.

\section{Start by explaining:}

At the beginning of our financial education sessions, we spent some time exploring our dreams and looking to the future. We shared our dreams for the future including:

- Where we would be living

-What we would doing

-What goals we would have reached

- We also talked about dreams we wanted to achieve in five years.

I want you to think about your dreams again. Now close your eyes for just a moment and think about yourself five years from now.

- Are your dreams the same as before?

- Has anything changed about your dreams now? If so, what has changed and why?
Make sure that all girls have at least reflected on their dreams then ask 3-4 volunteers to share responses to the above questions.

Ask:

S What about your savings goals? Have you had to change your savings goals? Has anyone reached their initial savings goal and set a new one?

Have girls share in groups of two or three and then ask if there are 3-4 volunteers that want to share about their evolving financial goals. Be sure to congratulate girls who have met their goals and encourage the girls who are still working on reaching their goals. Reassure them that saving is hard, but if they persist they will reach their goals in the end. 


\title{
activity 2
}

\section{RE-VISIT KEY TOPICS FROM THE FE CURRICULUM}

\author{
(2O MINUTES)
}

NOTE TO TRAINER: If you have a blackboard or blank flipchart paper available, use them for this session.

Say:

Over the past months we have been meeting together regularly to try and help each other develop some of the knowledge, skills, and attitudes we need to achieve some of our dreams. We have been exploring ways to make wise decisions about earning, spending, and saving money-all as a way to help us to achieve our dreams.

Now that we are at the end of our course, I wanted us to think about a little spider who spends her days dreaming about capturing and eating flies. Sometimes it must seem impossible for her to do. But what does she do to catch them? Have a few girls answer, until one speaks about making a web. Then ask:

\section{And how does a spider make her web?}

[She patiently weaves together many strands until the web is completed.]

Now I want us to see if we can weave together the many things that we have learned these past weeks - to see if we have enough strands in our web to catch our dreams! For just like the spider, with patience and persistence, plus a few new skills, we can achieve our dreams.
To do this we are going to start with this ball of string. To start weaving our web, I want to see if anyone in our group can give me an example of something we have learned together. (NOTE: you may have to give clues to the girls to remind them what the session was about.)

- Why save money (Give the string to the first person who has an idea and let them pass the strong on to someone else if there is another girl with an example-with each of them continuing to hold onto the string after they pass it so a web starts to form.)

- The difference between needs and wants (Have the string passed to one or two girls who have an answer, with each of them continuing to hold onto the string after they pass it so the web continues to grow.)

- Strategies for saving money regularly (Have the string passed to one or two girls who have an answer, with each of them continuing to hold onto the string after they pass it so the web continues to grow.)

- Dealing with setbacks in savings (Have the string passed to one or two girls who have an answer, with each of them continuing to hold onto the string after they pass it so the web continues to grow.)

- Talking about money with other people (Have the string passed to one or two girls who have an answer, with each of them continuing to hold onto the string after they pass it so the web continues to grow.)

- Dealing with conflicts about money (Have the string passed to one or two girls who have an answer, with each of them continuing to hold onto the string after they pass it so the web continues to grow.)

Different ways to earn more money (Have the string passed to one, or two girls, who have an answer, with each of them continuing to hold onto the string after they pass it so the web continues to grow.)

Finally, let's complete our web by finding out:

- Who has made a new friend in this safe spaces group (have the string passed to one or two girls who have an answer, with each of them continuing to hold onto the string after they pass it so the web continues to grow)

\section{- Who is a little bit closer to reaching their} dream (have the string passed to one, or two girls, who have an answer-making sure that by now everyone is holding the string)

Now look how strong our web is. How muc we have learned and grown together. 
activity 3

\section{LET'S CELEBRATE OUR ACHIEVEMENT}

\section{(15 MINUTES)}

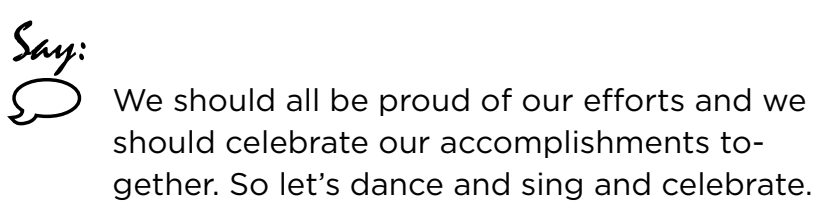

Invite girls to share dances and songs they know, and then perform them with the group. 


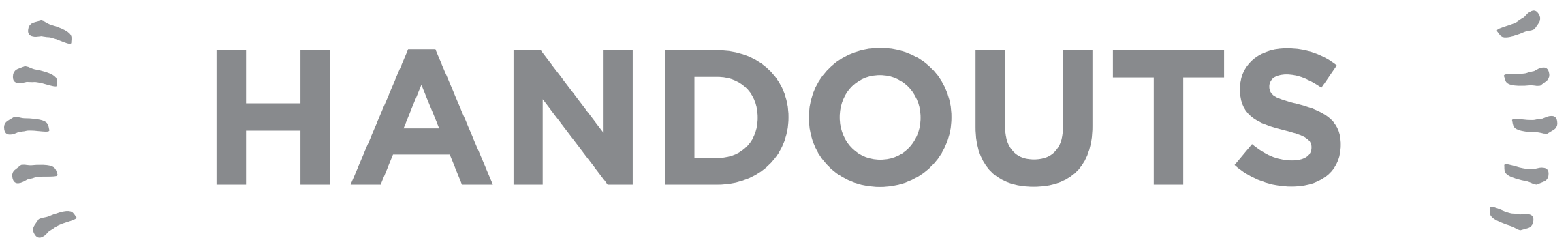

Use the handouts on the following pages for easy photocopying.

Each handout has a reference under the title that refers to the correct learning session and activity.

Have fun! 


\section{CHIKONDI'S STORY}

FROM session 1), activity 2

\section{Chikondi's Story}

Chikondi is 17 years old, and the oldest in her family. She stays with her mother and her three sisters in a two-room house in (Give an example of a community name in your area). Her mother struggles to pay rent and also to feed her girls but she is proud of Chikondi since she is so helpful with housework. Chikondi even earns some money to help the family by washing clothes for an elderly neighbor and by selling sweets to other pupils at her school.

Luckily, Chikondi and her sisters are smart, and Chikondi's mother was helped by the church with scholarships. All four of her children got sponsors who pay school fees for them in a nearby day school-though Chikondi has to use some of the money she earns to buy school supplies.

As a young girl Chikondi always told her mother that she wanted to be a dancer, just like the Famous Liseli sisters. Her mother always tells her: "that is not a future job for a person I gave birth to!" So every time Chikondi would run to the dancing grounds and practice dancing without her mother's knowledge. She also used some of the money she earned to buy refreshments for her friends at the dancing grounds-even if it meant not being able to buy all of the school supplies she needed, or saving any money for the dancer's costume she wanted to buy.

When Chikondi reached Grade 9, she dropped out of school. Even when her mother pleaded with her to stay in school and reminded her about her sponsorship she refused. One of her friends from the dancing group said he knew about a way she could make "easy money" and tricked her into leaving home and becoming an indecent club dancer. Chikondi's mum promised not to give up on her daughter so she visited a youth center and talked to the staff who agreed to help her find Chikondi and also provide counseling services. Finally she came back home and they trained her in dancing and acting at the youth center. Chikondi is now one of the prominent dancers in a popular dancing group that is sponsored by the youth center. She even makes money both performing at local celebrations and festivals. 


\section{SWOT CHART}

THINGS I KNOW ABOUT

MYSELF AND THE SPACE AROUND ME

FROM session 1), activity 3
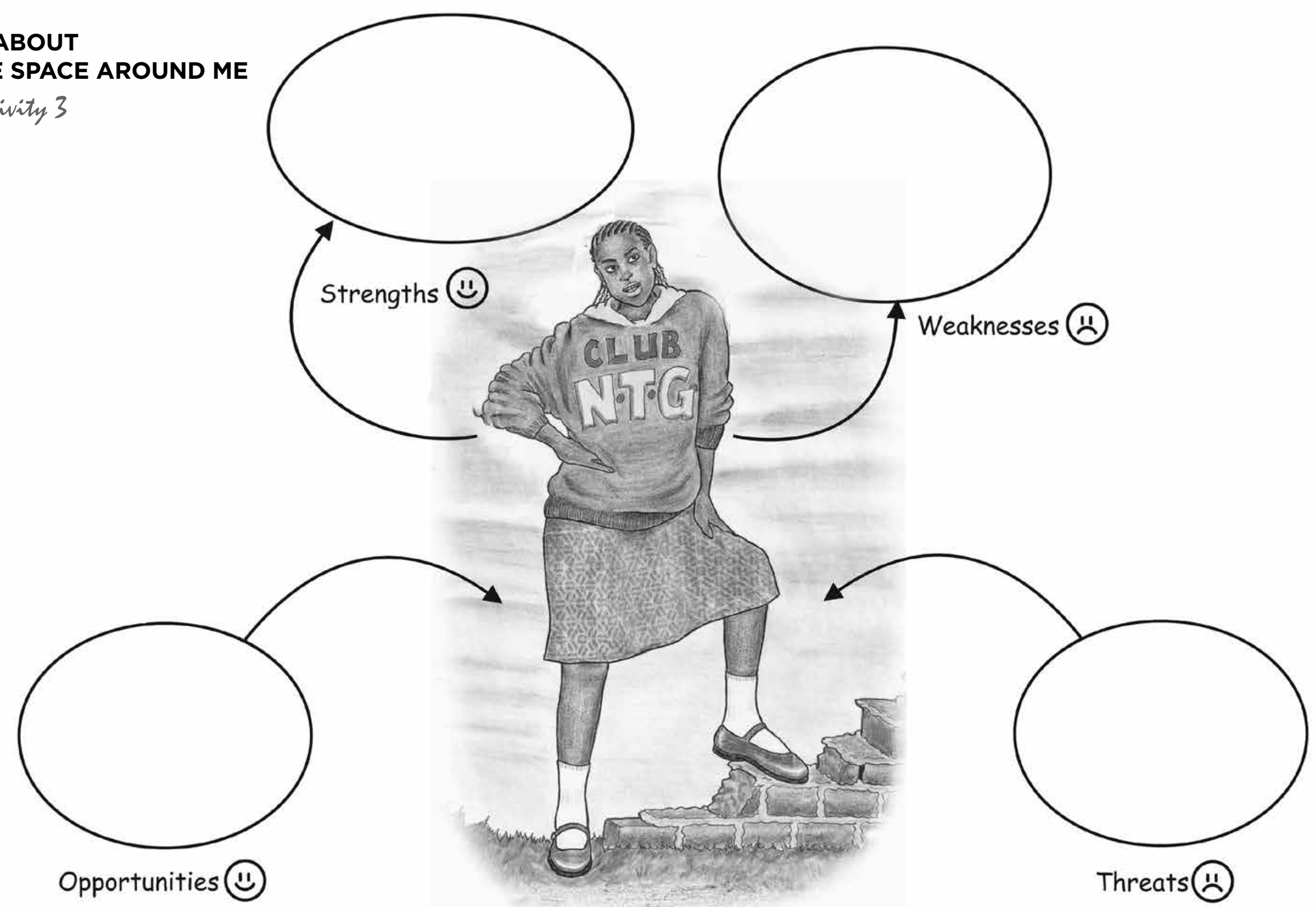


\section{EIGHT STEPS FOR SAVINGS}

FROM sessian 2), activity 1

\section{EIGHT STEPS FOR SAVINGS}

1. Choose a Savings Goal

2. Make a Savings Plan

3. Know the Difference Between Needs and Wants

4. Control Spending

5. Think About the Future: Money In and Money Out

6. Save Regularly

7. Save in a Safe Place

8. Deal with Setbacks in Saving 


\section{MONICA'S STORY}

FROM session 3), activity 3

\section{Monica's Story}

Monica is 18 years old and lives with her mother and younger brother. Her older sister, Mary, is married and lives in another town, two hours away. Mary just had a baby girl and Monica is eager to visit, to spend time with the baby and help her sister.

Monica will need money for transportation and a small gift for the baby. A cute little dress would be perfect! But she can't take money from her savings account for this trip because she is saving that money to start her own business. Monica's dream is to start a small business selling second-hand clothes (salaula). She hopes, her neighbor will employ her to work extra days in her salon so she can get the money she needs for her trip.

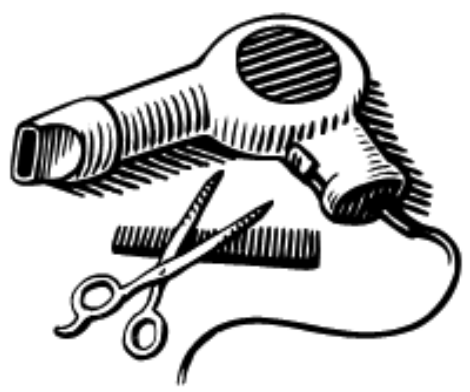




\section{PICTURE CARDS}

FROM session 4), activity 2

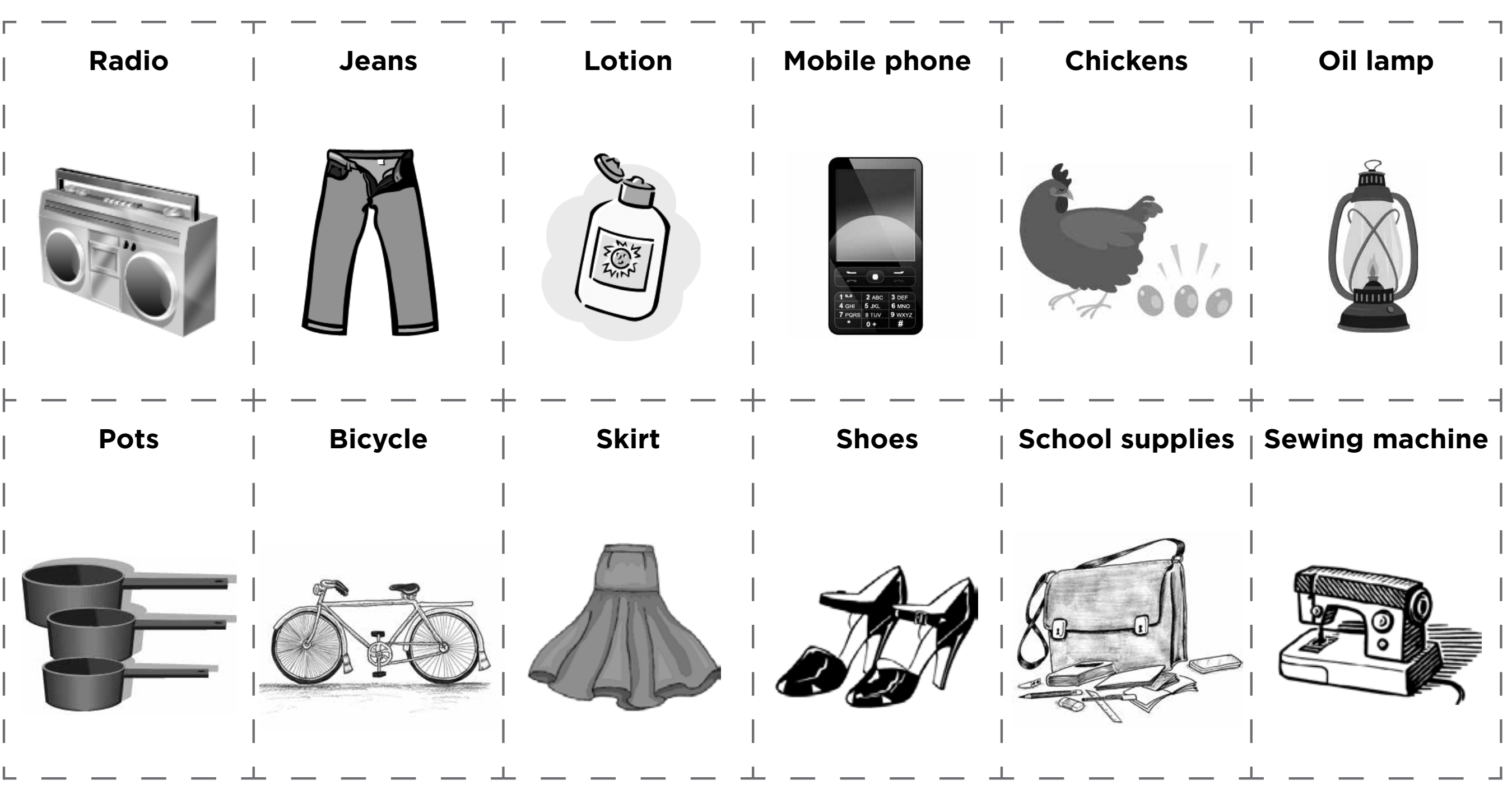




\section{SAVINGS PLAN WORKSHEET}

FROM session 4), activity 3

Sample

\begin{tabular}{|c|c|c|c|}
\hline Savings Goal & $\begin{array}{l}09 \\
\text { Total } \\
\text { (Cost of } \\
\text { item) }\end{array}$ & $\begin{array}{l}\text { Amount } \\
\text { you can } \\
\text { save each } \\
\text { week }\end{array}$ & $\begin{array}{l}\text { Number of } \\
\text { weeks you } \\
\text { need to reach } \\
\text { your goal }\end{array}$ \\
\hline $\begin{array}{l}\text { Short-term } \\
\text { New necklace }\end{array}$ & $K R 25$ & $K R 5$ & 5 weeks \\
\hline $\begin{array}{l}\text { Long-term } \\
\text { Attending } \\
\text { a computer } \\
\text { course }\end{array}$ & $K R 1,000$ & $K R 20$ & $\begin{array}{l}50 \text { weeks } \\
\text { (or almost } \\
\text { one year) }\end{array}$ \\
\hline
\end{tabular}

Tip: To find out how many weeks it will take to reach your savings goal, divide the total amount of money you need by the amount you can save each week.

Amount to save $\div$ Amount you can save each week = Number of weeks it will take
Do-it-yourself

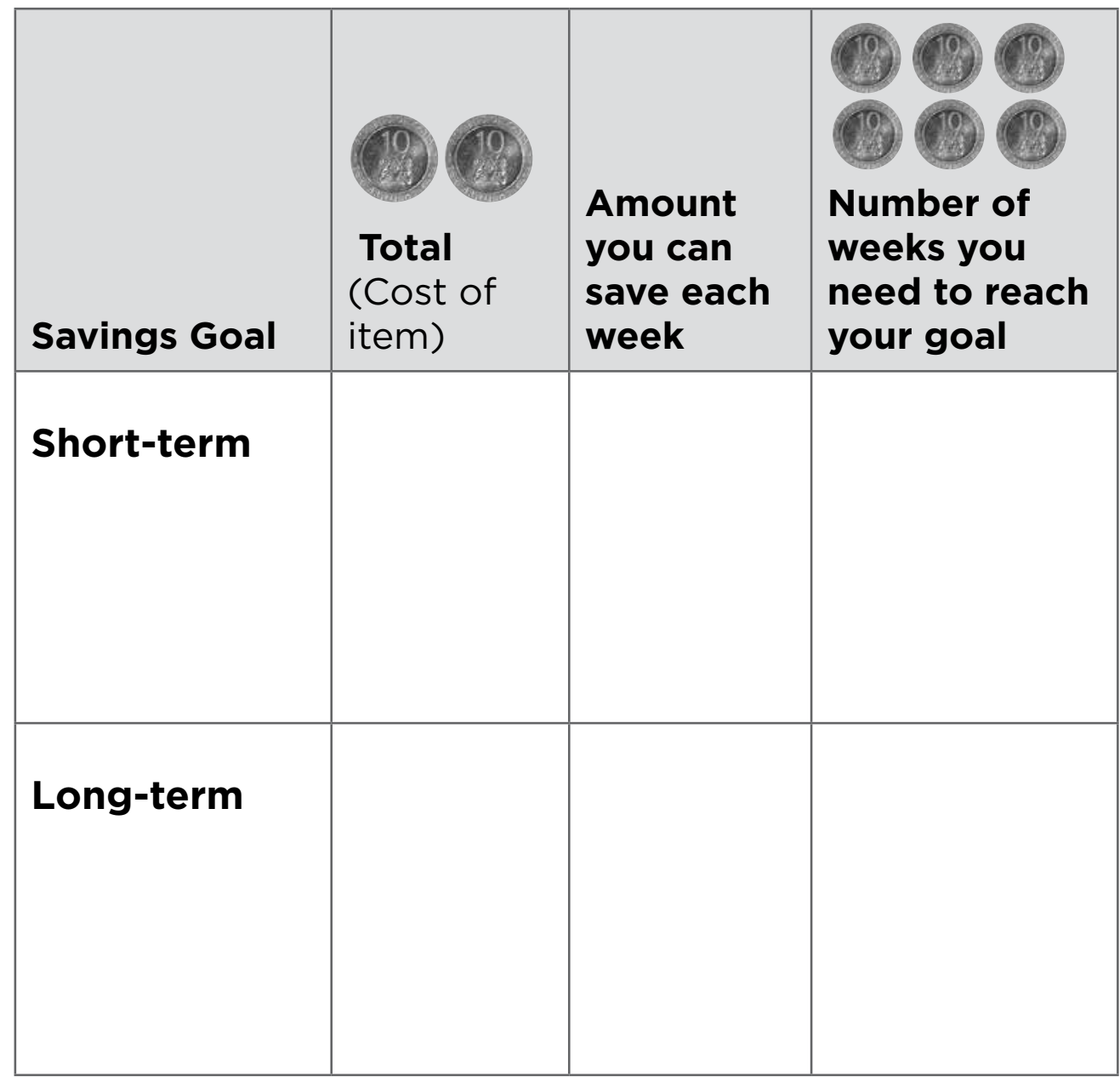




\section{NAMBULA'S STORY}

FROM session (), activity 2

\section{Nambula's Story}

Nambula needed money to help buy food for her family and meet her personal goals, so she started a business roasting maize and selling it to people in the market. At first business was good, but then more and more young people started to copy Nambula (even some of her friends) and business started to drop.

One thing Nambula noticed was that many customers bought a water to drink from another vendor after buying her maize-so she started to sell both roasted maize and water (giving a special price for people who bought both), and that helped grow her business again.

Next, she started to ask her customers what was the secret to the best roasted maize they had ever eaten. One said that in her home village she had once had roasted maize with fresh chilli sauce on it, and it had been delicious. So Nambula found a recipe for fresh chilli sauce and started to offer a shake of it on her client's maize. This kept some of her customers more loyal to her (and made it easier to sell more water too)!

Finally, Nambula paid close attention whenever she travelled to other markets to see if anyone was trying something new when it came to roasting maize. That is where she first found out about a special grill that used much less charcoal and thus increased profits for the maize vendor, at the same time reducing their cost. Once she saw it, she knew she had to save up to buy one since charcoal was always getting more expensive. 


\section{SAVINGS PLAN WORKSHEET}

FROM session 8), activity 2

\section{The Story of Bwalya and Mutinta}

Bwalya and Mutinta work together at a hair salon. The two girls each make about KR 400 each month.

Bwalya spends all of her money each month. Everybody thinks that Bwalya makes more money than Mutinta because Bwalya wears more new clothes and shoes. She often takes buses while Mutinta walks. Bwalya often buys Fanta and Coke at a local shop while Mutinta drinks water or tea at home. Sometimes she helps her friends when they need money, or buys them a soda as well. Bwalya also buys makeup whenever she has some money in her pocket. She never saves money.

Mutinta saves KR 50 each month. It has not been easy, but she has cut down a lot on spending money. Instead of buying new jewelry, she decided to continue wearing some of her old jewelry. She also has decided to wait a few months before buying a new pair of shoes. Even though she still buys snacks from time to time and gives some money to her mother for household needs, she has found that it is possible for her to save a little money by thinking about the difference between her needs and wants.

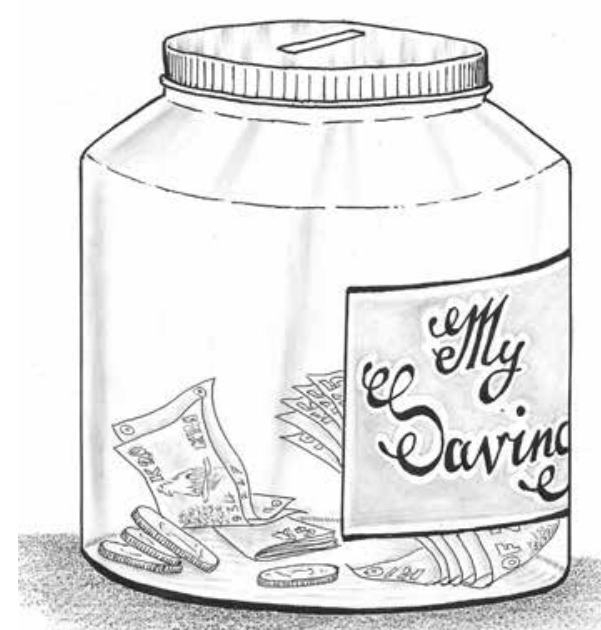




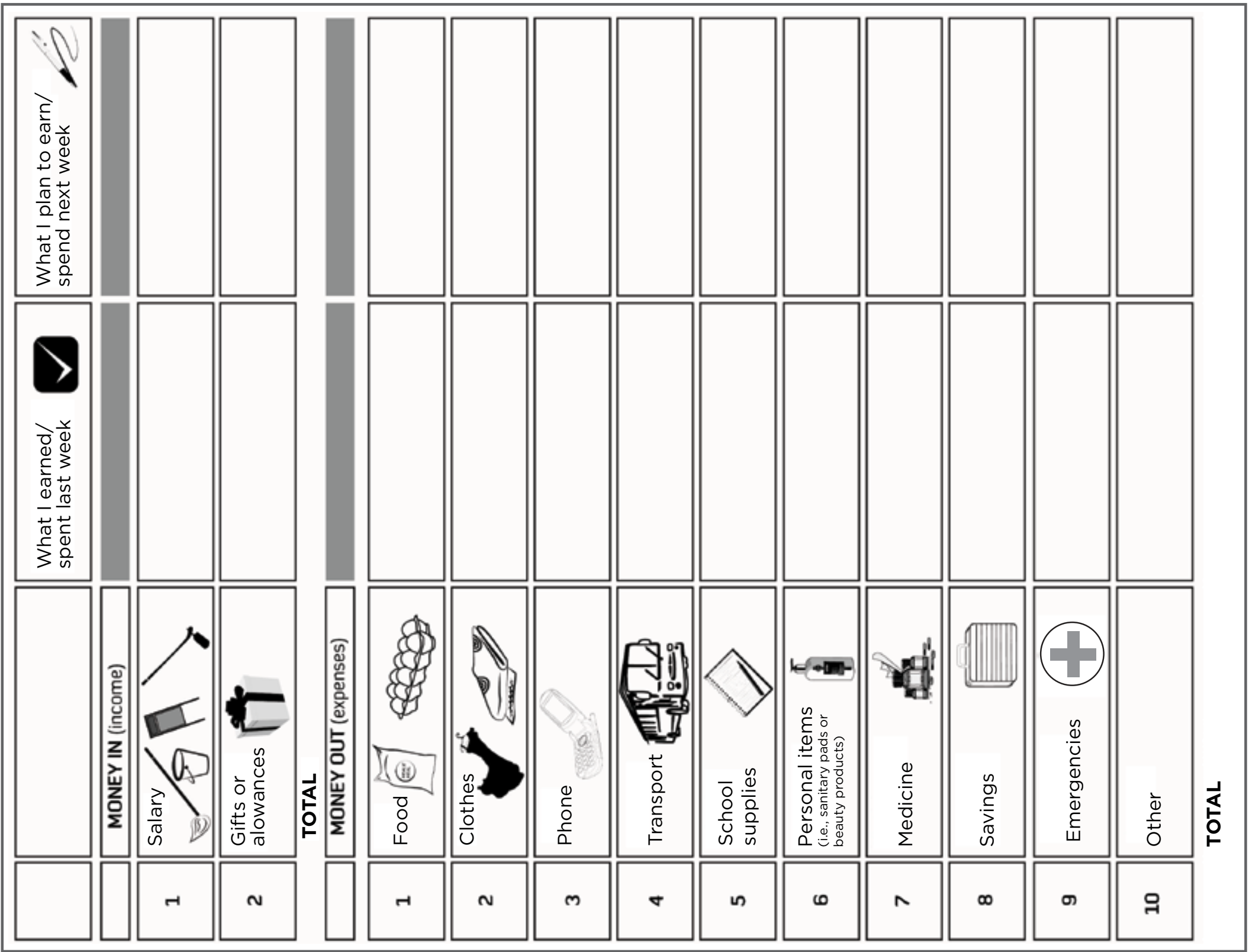




\section{MWAKA'S STORY (URBAN VERSION) Rural version on next page}

FROM session 10), activity 1

\section{Mwaka's Story [Urban]}

Mwaka is 17 and loves listening to radio programs. She listens to the radio whenever she gets the chance! She likes all programs-like the news, or educational programs-but her favorites are latest music hits. She is lucky because her aunt gave her a radio as a gift. Yet, she rarely has the money to buy batteries to keep the radio going.

Mwaka usually works one or two days a week as a waitress at her neighbor's restaurant or helping her aunt at her stall in the market and earns about KR 50 a day. Each week, Mwaka thinks about what she needs to spend money on, like food, transportation, or lotion. She sets aside the money she will need for those items and saves the little that is left with her savings group. She is saving that money to buy a sewing machine.

But sometimes she will keep a little extra at home, just in case she fails to get work in the coming week, or some other need for money comes up-as it usually does! However, every once in a while, Mwaka finds herself with a small amount of extra pocket money, and only then does she go to the shop to buy new batteries for her radio.

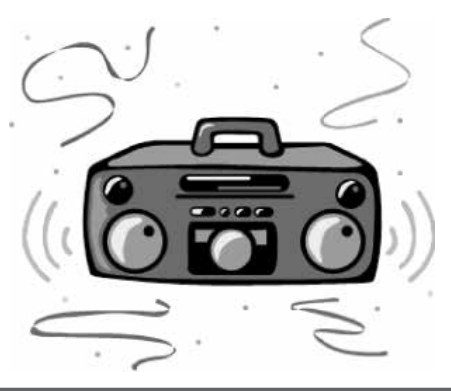




\section{MWAKA'S STORY (RURAL VERSION)}

FROM session 10), activity 1

\section{Mwaka's Story [Rural]}

Mwaka is 17 and loves listening to radio programs. She listens to the radio whenever she gets the chance! She likes all programs-like lima time, or educational programs-but her favorites are radio sketches in her own language. She is lucky because her grandfather has a radio she borrows sometimes to listen to her programs. Mwaka has an agreement with her grandfather that every time she wants to listen to the radio, she has to buy batteries because her grandfather can't afford any extra batteries. Moreover, Mwaka rarely has the money to buy batteries to keep the radio going each time she needs to listen to it.

Mwaka usually works one or two days a week weeding her neighbor's field or helping her aunt at her stand in the village market and earns about KR 20 a day. Each week, Mwaka thinks about what she needs to spend money on, like food, paraffin for the lamp, charcoal, or vaseline. She sets aside the money she will need for those items and saves the little that is left with her savings group. She is saving that money to buy a sewing machine.

But sometimes she will keep a little extra at home, just in case she fails to get work in the coming week, or some other need for money comes up-as it usually does! However, every once in a while, Mwaka finds herself with a small amount of extra pocket money, and only then does she go to the shop to buy new batteries to listen to her grandfather's radio. 


\title{
TWO COUSINS SAVE
}

FROM session 11), activity 2

\begin{abstract}
Two Cousins Save
Beatrice and Eva are cousins who live next door to each other. They decide that they can make some money selling fritters. Since they need the initial utensils and ingredients to start, the two girls make a promise to start saving so they can buy the necessary items. They know exactly what they want to buy and its price. They decide to save weekly and together agree on KR 100 that they think they can afford to save.

Eva is good at math; the cousins promise to each save KR five every week. So, they will save KR 10 in total each week. This means that they will have to save for 10 weeks before they can start the business. It seems like a long time, but by putting their savings together, it will go faster.

For the first few weeks, both cousins make sacrifices in order to save, and their family congratulates them! But Beatrice becomes tempted by her love for entertainment and goes to watch a variety show at her school. She even pays for a friend to go with her. Then her mother is sick and cannot work for a week, so Beatrice has to use some of her money to buy food for the house.

The next week, when Eva asks Beatrice for her savings, Beatrice just shrugs and says she can't afford to save right now. She promises to give Eva a bigger sum of money later, after she works at their neighbor's shop. "Don't worry," she says, "I'll work hard and save a lot next month. It will all work out the same."
\end{abstract}




\section{THE STORY OF MULENGA}

FROM session 12), activity 1

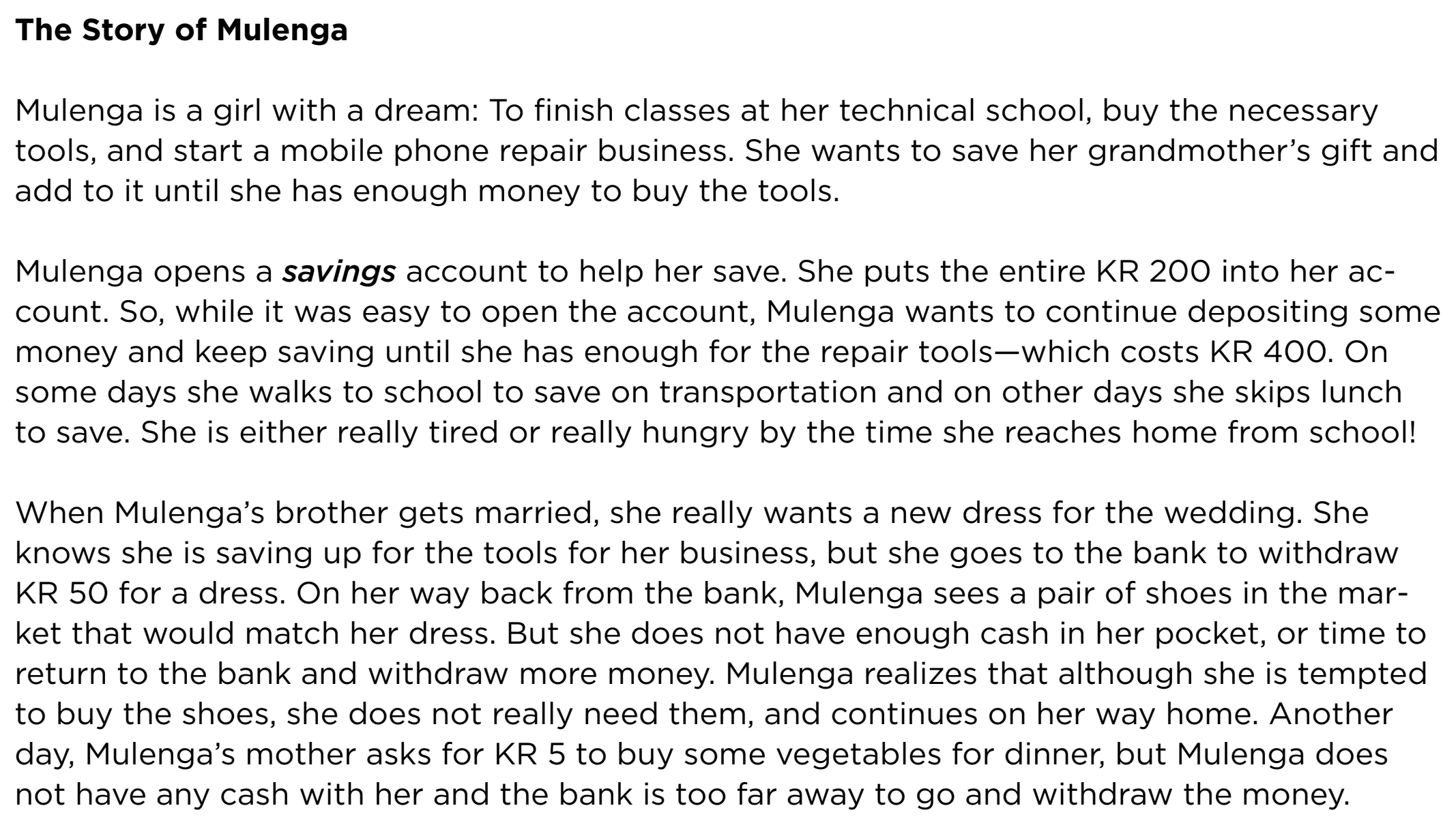




\section{THE STORY OF SARA}

FROM session 12), activity 2

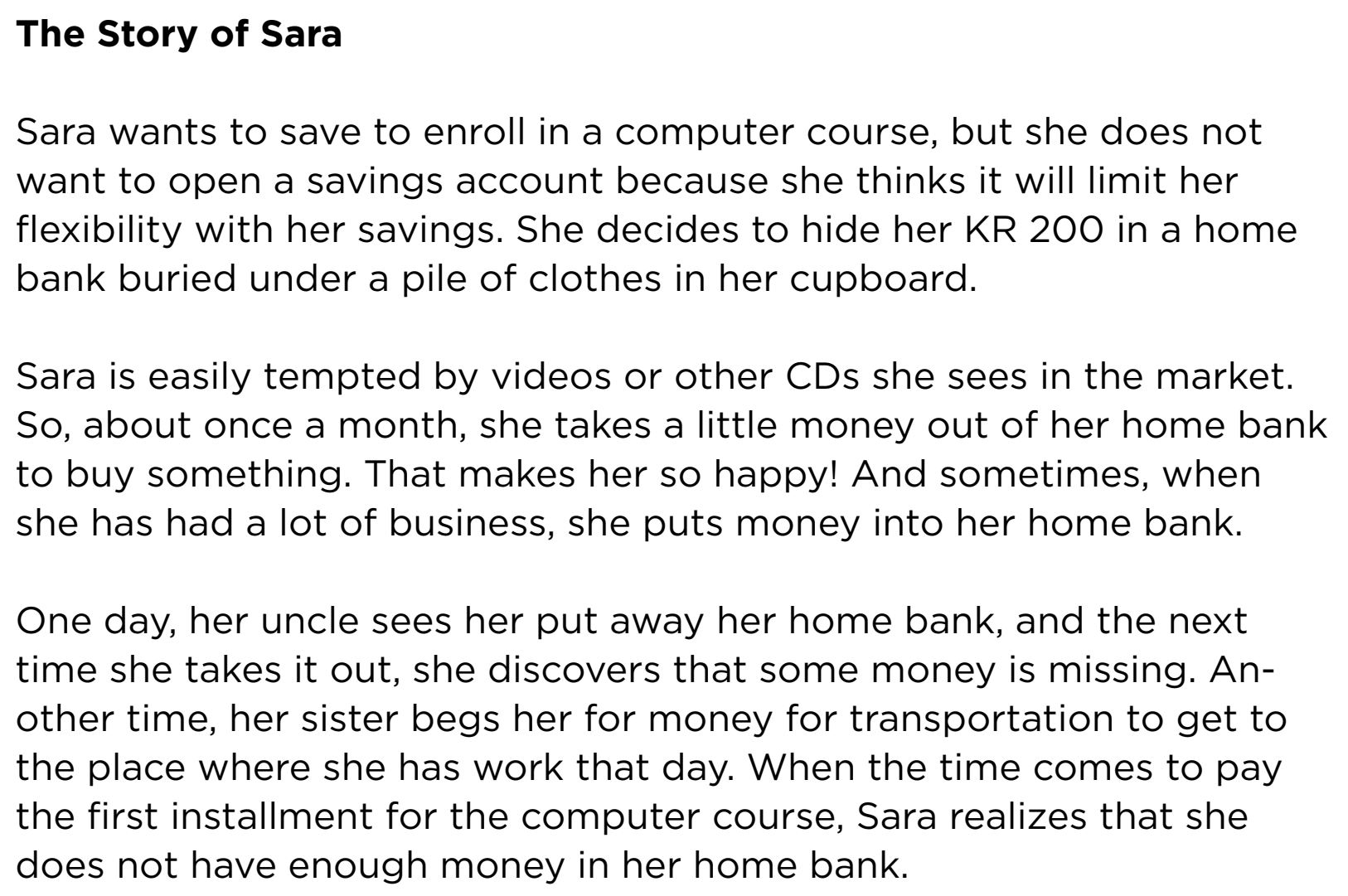




\section{THE STORY OF HELLEN}

FROM session 13), activity 3

\section{The Story of Hellen}

Hellen is a 14-year-old girl living with her older sister in [name of local community]. Her school is far from home so she gets on a bus twice a day to get to school and back home. Her older sister has to give her transportation money for school and lunch and her sister does not always have the money. As a result, Hellen sometimes misses school and her grades suffer because she gets behind in school work.

Lately, Hellen has been thinking of how she can make her situation better and not let her need for transportation money get in her way of attaining an education. She decides to make a savings plan to raise some money as a supplement toward her transportation costs. To do this, she starts a small business selling frizits (ice blocks) at school. Hellen needs capital of KR 35 to buy an initial box of frizits. She plans to raise this money by saving her school lunch money for two weeks. However, this takes much longer than she expected because sometimes her sister has no money to give her for lunch. She perseveres and manages to save KR 35 in four weeks, as opposed to the two weeks she initially planned. Just before Hellen sets off to by the ice blocks, her sister falls ill and she has to use the KR 35 for medicine. At least she went to her savings and not Patrick, her 27-year-old neighbor who gives her money sometimes.

Hellen begins saving for her capital again and this time it takes even longer (six weeks). She finally manages to buy the box of frizits to sell at school. The sales are very good in the beginning and her transportation money is covered for weeks to come. However, once the weather changes into the cold season, everyone stops buying frizits.

To keep her business alive so she can keep saving, Hellen decides to reinvest her capital in selling Jiggies and is able to make enough money not only to supplement her transportation to school, but also she also saves enough to buy small school requirements that she could not afford before. 


\section{POSSIBLE OUTCOMES WHEN TALKING ABOUT MONEY}

FROM session 15), activity 2

\section{Possible Outcomes when Talking About Money}

\section{Win-Win}

This is the best outcome in any discussion about money. Both people (or groups) involved in the discussion get something or everything they want or need. They both have a positive feeling at the end of the discussion, and are willing to talk about money again in the future.

\section{Lose-Lose}

This is the worst possible outcome in a discussion about money. In this outcome, the two people (or groups) cannot agree. In the end, neither person (or group) involved in the discussion gets what they wanted. They may not be willing to talk about money again in the future.

\section{Win-Lose / Lose-Win}

In a win-lose or lose-win situation, one person (or group) gets what she wants and the other gets nothing. When this happens, the loser might be less likely to want to talk to the winner about money again in the future.

Outcome:

An outcome is the result of something. When we are talking about money, we use outcome to mean the result of the discussion. 


\section{A CONVERSATION BETWEEN A MOTHER AND DAUGHTER}

FROM session 17), activity 2

(OPTION ONE-URBAN)

\section{A Conversation Between a Mother and Daughter}

Daughter: Hello, mother. I want to talk to you about something important. Do you have a few minutes now?

Mother: I have to go out soon to work in my shop. Let's make it quick!

Daughter: Mother, now that I am older and part of a group, I am learning many new things. I have to travel across town for my group and for school. l'd like my own mobile phone. I know they are expensive but...

Mother: (cutting her off) You always want something-usually something expensive! You know money is tight in this family!

Daughter: But mother, a mobile phone wouldn't just be for me. Now that Sampa and Chola, my younger brothers, will be going to school, and I have to collect them at the end of the day, and do errands for you and father.

Mother: Young lady, you do not seem to realize that there are many things that I need to buy for our household. I have to decide how to spend this money in everyone's best interest.

Daughter: I'm sorry. I didn't mean to make you angry. I know it is difficult to manage so many demands on our budget. I can wait to get a mobile phone. Do you think it would be possible for me to come up with a plan to buy a mobile phone in the future? I'm saving money now, and I am earning some money helping Mama Moses in her salon. It isn't much, but if I save, I can have enough for half of the price in two months. If I am able to save that money, would you consider helping me pay for the rest?

Mother: I suppose I could consider that. But don't expect me to pay for your talk time! 


\section{A CONVERSATION BETWEEN A MOTHER AND DAUGHTER}

FROM session 17), activity 2

\section{(OPTION TWO-RURAL)}

\section{A Conversation Between a Mother and Daughter}

Daughter: Hello, mother. Can I talk to you about something important? Do you have a few minutes now?

Mother: I have to go out soon to work at the stand in the market. Let's make it quick!

Daughter: Mother, now that my baby Chimwemwe is older and not breastfeeding any more, I'm thinking it's time I went back to school. Most of the girls in our girls group meetings have gone back to school even after having their...

Mother: (cutting her off) We have had that conversation before. How much more explaining do I have to do to make you understand that this family is not making enough money for all of you to be in school. It's already hard trying to keep your brothers in school. It just has to wait until there is enough money. Besides you being older, you must be doing something and contribute toward helping the family get around these problems. You know that school costs way more than that.

Daughter: But mother, we have been putting my school on hold for three years now. I'm not getting any younger. All my friends are almost completing school now. Does this mean I'm never going back to school? Besides, going back to school is the only way I can relieve you of having to take care of both me and my child too in future.

Mother: Young lady, you do not seem to realize that there are many things that I need to buy for our household. I have to decide how to spend this money in everyone's best interest.

Daughter: I'm sorry. I didn't mean to make you angry. I know it is difficult to manage so many demands on our budget. I can wait to get back into school. Do you think it would be possible for me to come up with a plan to help you pay for my school fees? I'm saving money now, and I am earning some money helping Mama Moses in her salon. It isn't much, but if I save, I can make enough to pay half of my schools fees. If I am able to save that money, would you consider helping me pay for the rest?

Mother: That's a good idea. I suppose I could consider that. But just remember that we may need to cut down on many other expenses that are not priority right now. 


\section{CONFLICTS ABOUT MONEY: ROLE PLAYS}

FROM session 18), activity 1

1. Corrinne helps her grandmother on Saturday mornings at her hotel near the market. She wants to keep this money herself. But her mother insists that Corrinne give her all of the money to help with household expenses.
2. Michelo has a motorbike which he uses to transport customers every day after school. He is saving to move to Kabwe from Chibombo. But his parents oppose his plans to leave their rural home. They need him at home to help with expenses.
3. Fatima gets money each week from her parents for her bus fare and lunches at school, and saves what is left over with her savings group. When her parents learned that Fatima had a little to save at the end of each week, they got angry. They threatened to reduce her allowance, but Fatima wants to keep a little money as her own.

4. Nosiku and Pamela are sisters
who work in the same market
stand every day. They get money
from their parents to take the
bus to the market. However,
Pamela now wants them to walk,
and save and split their trans-
portation money.

5. Emily recently worked for a neighbor for five days. However, when she went to collect her earnings, the neighbor said she had only worked for four days. Emily wants to resolve the situation and still collect her earnings. 
Austrian, Karen and Caroline Sakwa. 2006. Financial Literacy Program for the Binti Pamoja Centre. Nairobi.

Bayiga, Julie, David James-Wilson, Kyagaza Esras, and Lisa Parrott. 2009. Mobilizing Young People's Resources for Education (DRAFT). Kampala: Save the Children.

Fisher, Roger, William L. Ury and Bruce Patton. 1992. Getting to Yes: Negotiating Agreement Without Giving In, 2nd Edition. Boston: Houghton Mifflin.

Fisher, Roger and Scott Brown 1998. Getting Together: Building Relationships As We Negotiate. New York: Penguin Books.

Global Financial Education Program. 2010. Young Women: Your Future, Your Money. Washington, DC: Microfinance Opportunities.

Godfrey, Neale S. and Carolina Edwards. 1994. Money Doesn't Grow on Trees: A Parent's Guide to Raising Financially Responsible Children. Fireside, NY: Children's Financial Networks.

Nelson, Candace. 2008. Young People: Your Future, Your Money. Washington, DC: Microfinance Opportunities.

Nelson, Candace, Jessica Massie and Bailey Butzberger. 2010. Jeunes Filles: Votre Avenir, Votre Argent (Financial Education for CARE Burundi). Washington, DC: Microfinance Opportunities.
Perdomo, Maria. 2008. Savings: You Can Do It. Technical Learning Conversations for Avançons Afrique de l'Ouest. Davis, CA: Freedom from Hunger.

Population Council and Microfinance Opportunities. 2011. Young Women: Your Future, Your Money--Workbook for Girls Ages 10-14 in Kenya. Nairobi.

Population Council and Microfinance Opportunities. 2011. Young Women: Your Future, Your Money--Workbook for Girls ages 15-19 in Kenya. Nairobi.

Population Council and Microfinance Opportunities. 2011. Young Women: Your Future, Your Money--Workbook for Girls ages 10-14 in Uganda. Nairobi.

Population Council and Microfinance Opportunities. 2011. Young Women: Your Future, Your Money--Workbook for Girls ages 15-19 in Uganda. Nairobi. 
For more information, contact

Population Council - Zambia

Plot 3670 No. 4 Mwaleshi Road

Olympia Park, Lusaka

P/Bag RW 319X, Lusaka 10101, Zambia

Lusaka, Zambia 10101

Tel: +260 211295925

www.popcouncil.org 